\title{
CONTEXTOS FUNERARIOS ATAVILLOS EN PURUNMARCA, VICHAYCOCHA - HUARAL
}

\author{
Pieter D. VAN DALen LUNA \\ UniVERSIDAD NACIONAL MAYOR DE SAN MARCoS \\ pvandalen2@hotmail.com
}

\section{RESUMEN}

La cuenca alta del río Chancay-Huaral, ocupado por la cultura Atavillos en periodos prehispánicos tardíos, es un territorio casi desconocido, a pesar de existir numerosos asentamientos de gran importancia como Rupac, Chiprac, Añay, Cachirmarca, entre otros. San Miguel de Vichaycocha es la comunidad campesina de mayor altitud en la cuenca, limitando con la provincia de Huayllay vía la cordillera de Antajirca, zona donde se realizaron las interacciones entre los Atavillos y otros pueblos como los Chinchaycocha, Yaros, etc. En el ámbito de esta comunidad existen numerosos asentamientos Atavillos, siendo el más importante el de Purunmarca, donde las investigaciones con excavaciones de la temporada 2014 permitieron identificar áreas de actividad múltiple, al igual que las características de los contextos funerarios.

PalabRas Claves: arqueología, Atavillos, cuenca del río Chancay, contextos funerarios, kullpi, chullpa.

\begin{abstract}
The upper basin of the river Chancay-Huaral, Atavillos occupied by the pre-Hispanic culture in late periods, is an almost unknown territory, despite the existence of numerous settlements of great importance as Rupac, Chiprac, Añay, Cachirmarca, among others. San Miguel de Vichaycocha farming community is the highest altitude in the basin, bordering the province of Huayllay via Antajirca Range area where interactions between Atavillos and other peoples as Chinchaycocha, Yaros, etc. were performed In the area of this community there are numerous settlements Atavillos, the most important of Purunmarca, where research with excavations of the 2014 season helped identify areas of multiple activity, as well as the characteristics of the funerary contexts.
\end{abstract}

KEYWoRDS: archeology, Atavillos, Chancay river basin, funerary contexts, kullpi, chullpa. 


\section{INTRODUCCIÓN}

El año 2014 el autor del presente artículo realizó investigaciones arqueológicas con excavaciones en un sitio de la cultura Atavillos ubicado a 4000 metros de altitud, en compañía de docentes, bachilleres y estudiantes de la EAP de Arqueología de la Universidad Nacional Mayor de San Marcos, institución que auspició y financió los trabajos a través del Vicerrectorado de Investigación, en el marco de los proyectos de investigación con-con 2014. De igual manera, la Comunidad Campesina San Miguel de Vichaycocha, financió otra parte de los gastos efectuados y sus comuneros participaron en las investigaciones mediante "faenas comunales".

Las investigaciones arqueológicas permitieron conocer al detalle las características de las ocupaciones en este importante asentamiento Atavillos, que por su ubicación mantuvo relaciones tanto con pueblos Chinchaycochas de las punas de Junín y Pasco, como con pueblos de la chaupiyunga en el fondo del río Chancay.

En esta oportunidad presentamos únicamente los resultados de las investigaciones sobre los contextos funerarios recuperados del sitio arqueológico de Purunmarca, ubicado en la jurisdicción de la Comunidad Campesina de San Miguel de Vichaycocha, en la provincia de Huaral; quedando pendiente otros artículos con los detalles de las excavaciones en su totalidad y los análisis de la arquitectura que conforma el sitio.

\section{El sitio arqueológico de Purunmarca}

\section{1.- Ubicación}

El sitio se encuentra ubicado en la ladera superior y cima del cerro Purunmarca, ubicado en la margen izquierda del río Vichaycocha, en el contrafuerte que divide las cuencas de los ríos Vichaycocha y Chicrín, en los terrenos de la comunidad Campesina de San Miguel de Vichaycocha, distrito de Pacaraos, en las coordenadas UTM: N8767460 y E0322964 (WGS-84), a 3910 metros sobre el nivel del mar. El medio ambiente es frío, presentando la ladera del cerro abundante vegetación de tipo herbácea, arbustiva y cactácea.

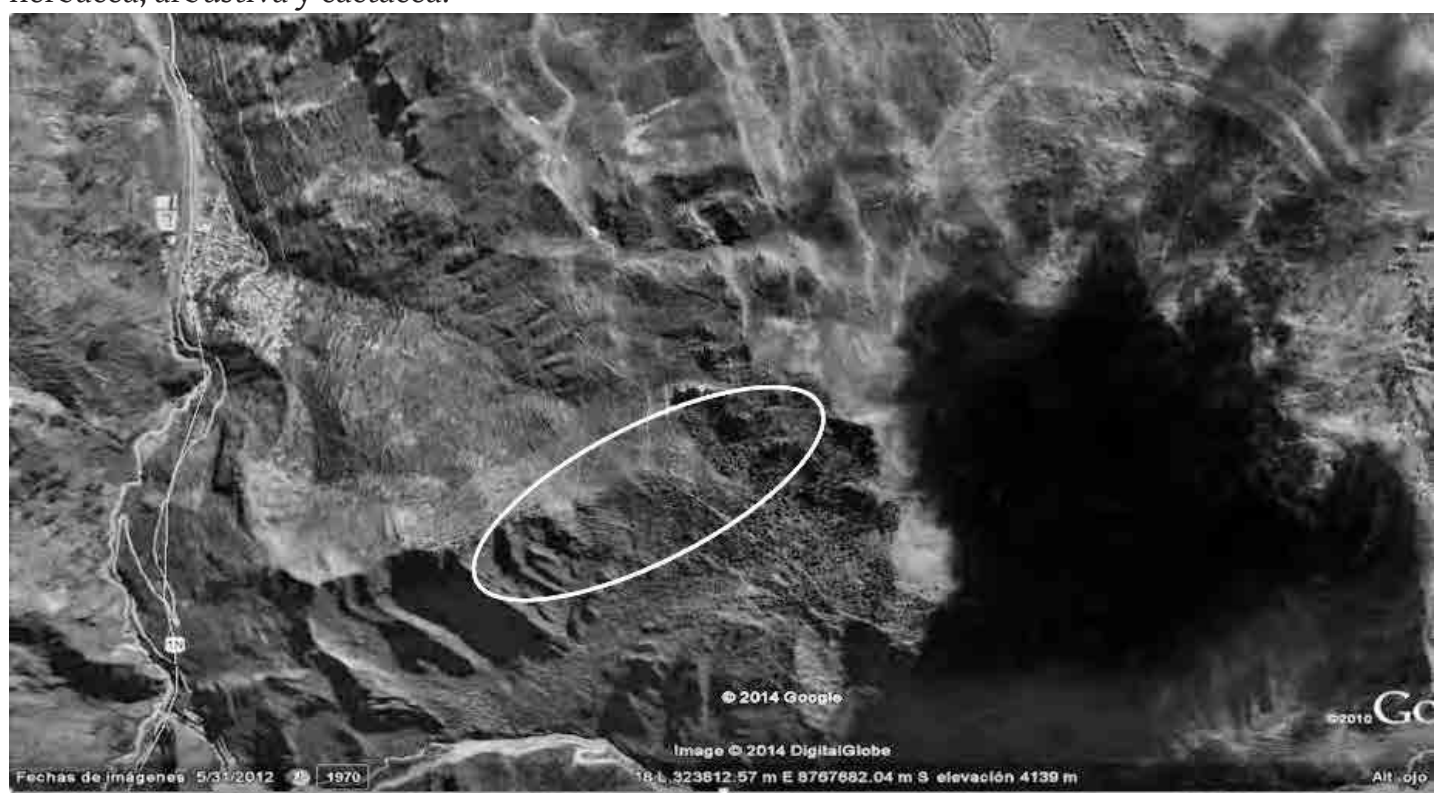

Figura 1: Fotografía satelital mostrando la ubicación del sitio arqueológico de Purunmarca en relación al río Vichaycocha (izquierda) y el pueblo de San Miguel de Vichaycocha. 


\section{2.- Características del sitio}

El sitio arqueológico de Purunmarca es un asentamiento tardío, uno de los más importantes de la cuenca alta del río Chancay-Huaral. Se encuentra emplazado sobre la cima y ladera superior del cerro Purunmarca, con un largo de aproximadamente 450 metros por 70 metros de ancho, flanqueado por profundos acantilados que dan al río Chicrín por el lado suroeste y al valle de Vichaycocha por el noreste. Los conjuntos arquitectónicos están conformados por chullpas y kullpis distribuidos alrededor de patios empedrados. Estos conjuntos se emplazan sobre aterrazamientos consecutivos simples de entre uno y dos metros y medio de altura elaborados para lograr la horizontalidad del terreno.

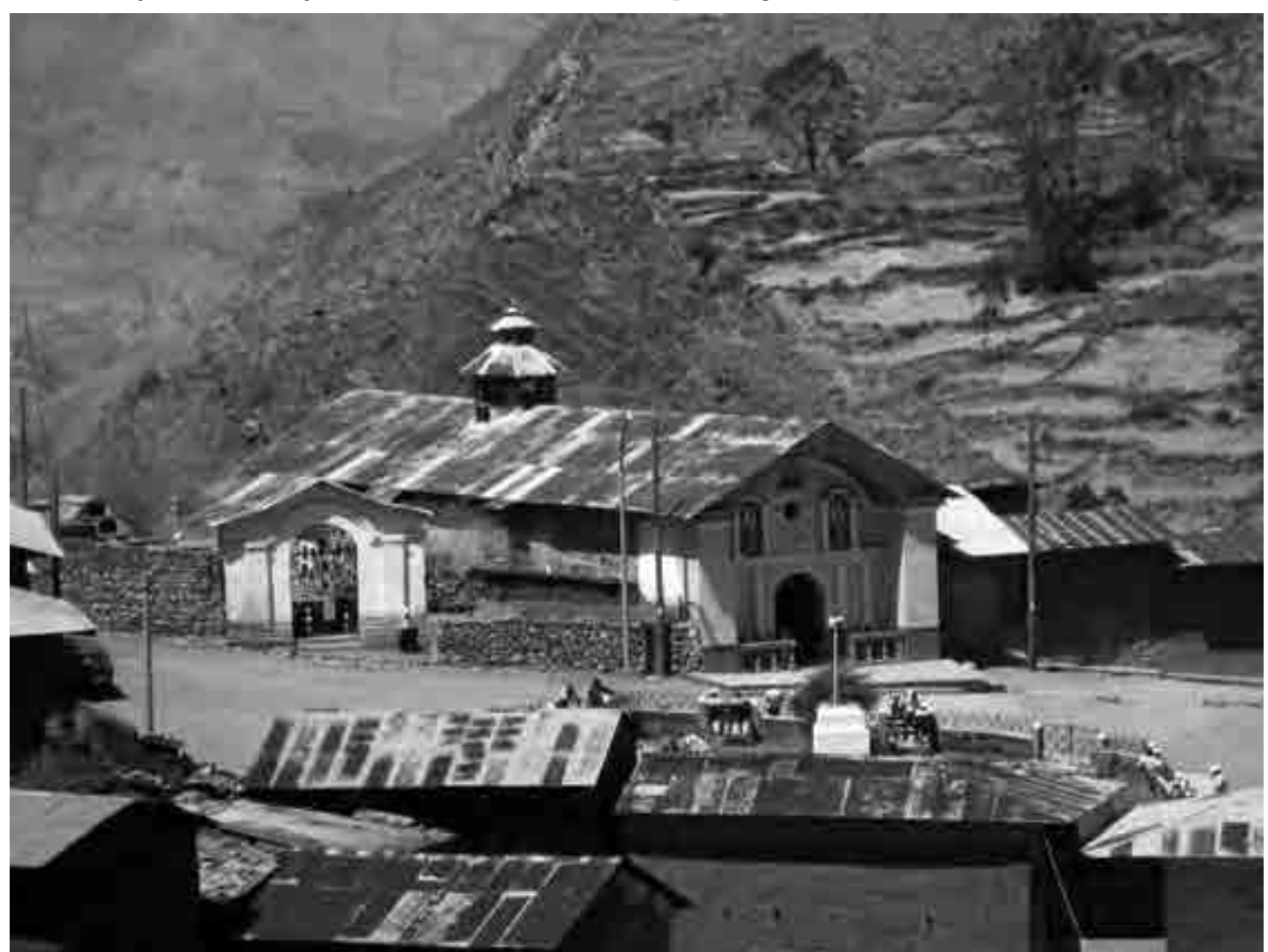

Figura 2: Vista panorámica de la plaza del pueblo de San Miguel de Vichaycocha con su iglesia matriz, la cual fue edificada en la Colonia Siglo XVI) con las piedras desmontadas del sitio arqueológico de Purunmarca.

Las construcciones del tipo Kullpi, llegan a tener hasta cuatro metros y medio de altura, mientras que las chullpas son más pequeñas, llegando a tener 1.50 metros de altura, con fines puramente funerarios. Existen alrededor de 50 a 70 edificaciones tipo Kullpi, de las cuales 15 se encuentran en buen estado de conservación, hallándose preferentemente en la parte baja del asentamiento. Las características de los Kullpis son similares a los de sitios cercanos como Ninas y Santa Cruz, presentando planta cuadrangular, edificados a base de piedras trabajadas, con una cámara interna central principal de forma cuadrangular con esquinas ovaladas, al cual se accede desde el exterior por un vano muy pequeño de forma rectangular, de 0.60 metros de alto y 0.45 metros de ancho. La cámara interna presenta hornacinas cuadrangulares y cámaras pequeñas de 0.40 por 0.40 metros que se comunican entre sí mediante pasadizos horizontales que dan la vuelta alrededor de la cámara principal en diferentes niveles superpuestos. 

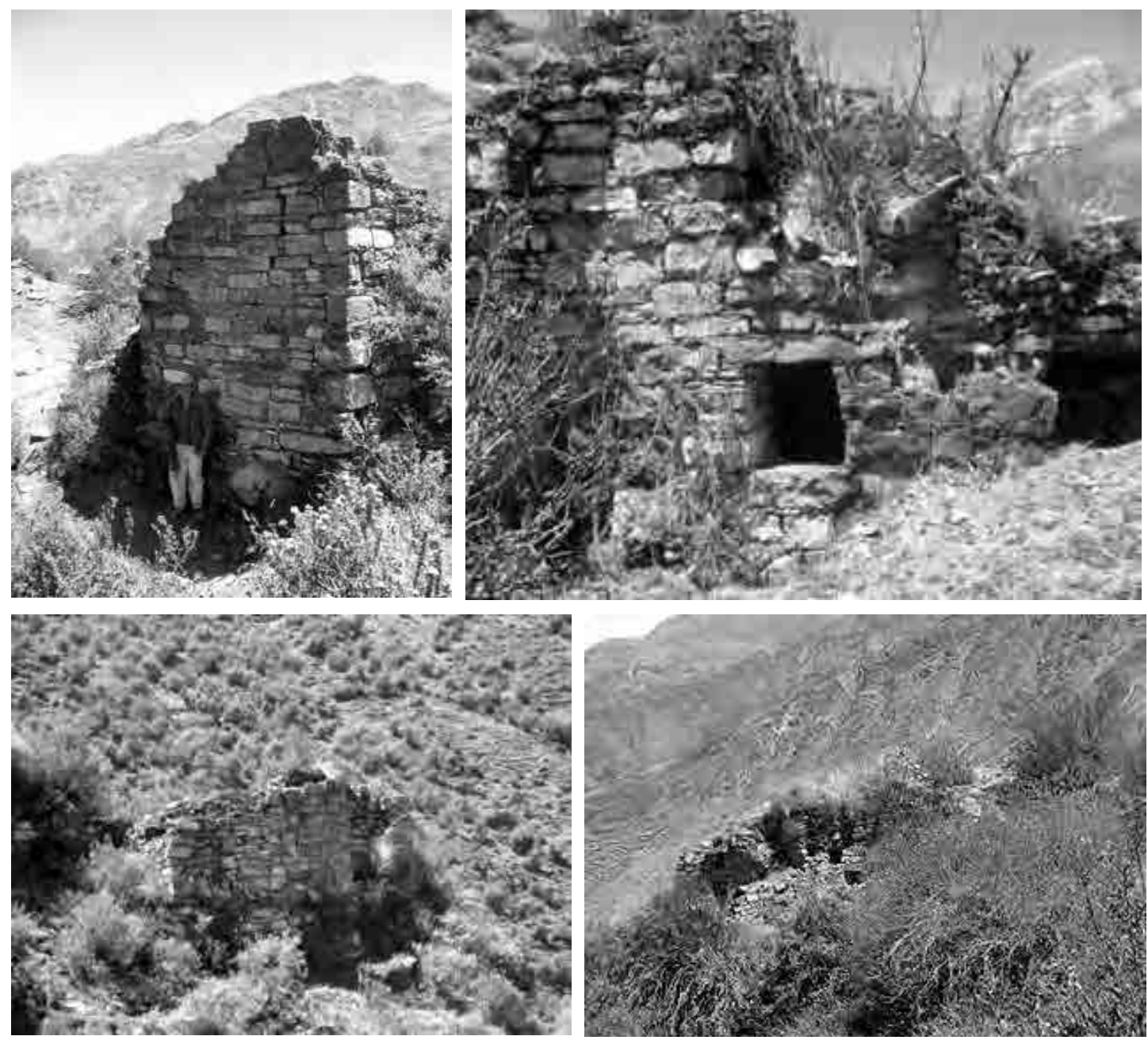

Figura 3 (Superior izquierda): Vista de un Kullpi del sector medio. Figura 4 (superior derecha): Vista de otro kullpi del sector bajo. Figura 5 (inferior izquierda): Kullpi del sector bajo. Figura 6 (Inferior derecha): Conjunto de kullpis en el extremo inferior del sector bajo.

Existen en los Kullpis de Purunmarca hasta seis niveles superpuestos cada uno en un eje horizontal. En el interior de las cámaras superiores se identificó pocos restos óseos humanos. El acceso a éstas cámaras se realiza mediante voladizos. La cubierta interna tiene forma de cúpula y está elaborado mediante lajas consecutivas salientes, que hace que el espacio se vaya ensanchando. La cubierta externa es plana, con una gruesa capa de barro mezclado con paja y fragmentería cerámica en la parte superior, para proteger la edificación de las lluvias. Todas las edificaciones están elaboradas con piedras labradas, con pachillas intermedias (para rellenar los espacios faltantes), unidas con argamasa de barro. El segundo tipo de construcciones son las chullpas, de carácter puramente funerarios, se pueden presentar aisladas o aglutinadas en conjuntos (una junto a otra). Tiene un vano pequeño, de 0.50 metros de altura, presentando en su interior abundante osamentería humana, en varias cámaras. Al parecer se trataría de entierros múltiples. En la parte baja del sitio se aprecian rocas naturales, en cuyos farallones se encuentran entierros. 


\section{3.- Sectorización}

El sitio arqueológico de Purunmarca está conformado por tres sectores:

- Sector A o Sector Alto: Está conformado por un aproximado de 25 edificaciones tipo Kullpis. Se accede a este sector a partir del camino de herradura que proviene del mismo pueblo de San Miguel de Vichaycocha.

- Sector B o Sector Medio: Está conformado por un aproximado de 35 edificaciones tipo Kullpi y Chullpas, distribuidas alrededor de patios empedrados.

- Sector C o Sector Bajo: Conformado por cerca de 30 edificaciones de las mismas características que los anteriores.

\section{4.- Estado de conservación}

El sitio de Purunmarca se encuentra en mal estado de conservación, la mayoría de sus construcciones se encuentran colapsadas, principalmente por el desmontaje de sus muros durante la colonia, como por la actividad de pastoreo que se realiza constantemente por la Comunidad de Vichaycocha en sus alrededores. Además, las edificaciones son afectadas por las fuertes lluvias que azotan la zona.

\section{5.- Antecedentes de estudio}

Si bien es cierto que los distritos altoandinos de la provincia de Huaral, han sido muy poco investigados en todos los campos científicos, el distrito de Pacaraos, no tiene ninguna investigación arqueológica con intervención directa en los sitios. Es por ello, que el conocimiento acumulado acerca de las formaciones socio políticas que ocuparon este territorio en periodos prehispánicos es aún desconocido.

En los demás distritos de la cuenca alta del río Chancay - Huaral, hay muy pocas investigaciones. El padre Pedro Villar Córdova en su obra: “Arqueología del departamento de Lima”, menciona algunos sitios del alto Huaral, entre estos el de Marca Piche, Auquihuilca, Rúpac, Chiprac, Añay, Yaros, entre otros, definiendo sus características arquitectónicas y culturales, conformantes de los Atavillos (Villar 1982).

El año 2005, las arqueólogas Diana Antezana y María Díaz (Antezana y Díaz 2005), publicaron los resultados de los estudios en el sitio de Puchuni, en las cercanías de Pirca en el distrito de Atavillos Alto. Ellas han identificado cuatro sectores: El sector I, ubicado al lado Nor Oeste, que corresponde a corrales y áreas de cultivo; el sector II, ubicado en la parte central, que corresponde al área residencial; el sector III, ubicado hacia el Oeste, que presenta aterrazamientos y unidades arquitectónicas aisladas; y el Sector IV, ubicado al Sur Este, conformado al igual que el sector I, por corrales y áreas de cultivo. Asimismo, han podido identificar en base a las características espaciales cuatro tipos arquitectónicos, correspondientes a edificios y espacios abiertos.

El mismo año Daniel Cáceda Guillén (Cáceda 2005) reportó los resultados de sus investigaciones en los sitios de Rúpac, Chíprac, Añay y Cerro Mango, basándose en análisis arquitectónico y de material cerámico.

El año 2007 se publicó (van Dalen 2007) el artículo: “Reconocimiento arqueológico en la cuenca alta del río Chancay - Huaral: margen izquierda (distritos de Atavillos Alto, Santa Cruz de Andamarca y Pacaraos). Nuevos datos para comprender los procesos socio- culturales Atavillos". En base al 
reconocimiento arqueológico en la cuenca superior del río chancay - Huaral, distritos mencionados, se plantea una nueva visión sobre los Atavillos, considerándolos como una variedad de entidades político - sociales, a razón de cada subcuenca importante, los cuales se hallaban interrelacionados y amalgamados con fines defensivos, ideológicos, y comerciales. Se realizó una tipología de asentamientos (entre estos Purunmarca) clasificándolos en siete tipos en base a las características espaciales y arquitectónicas propias.

El año 2010 (van Dalen 2010-b), se publicó otro artículo referido a las investigaciones realizadas en el sitio arqueológico de Marca Piche, en la Comunidad de Baños, distrito de Atavillos Alto, en el cual se describe las características de cada uno de los sectores conformantes del asentamiento, así como su interrelación con otros asentamientos cercanos. Estas propuestas fueron ampliadas en un posterior trabajo (van Dalen 2014).

\section{LAS INVESTIGACIONES ARQUEOLÓGICAS EN LA TEMPORADA 2014}

Durante la temporada 2014 se procedió con el mapeo y la excavación de 13 unidades de diferentes dimensiones $(4 \times 4,8 \times 8,8 \times 2)$, distribuidas en los tres sectores del sitio, con el objetivo de definir los periodos de ocupación en el sitio y en base a los materiales culturales asociados a cada periodo, definir las características culturales y de ocupación de cada uno de estos, así como el definir la funcionalidad de los espacios arquitectónicos. El método de excavación fue el método tradicional, siguiendo la excavación por subunidades (según la distribución de los espacios arquitectónicos) y al interior de estas por capas culturales. Se utilizó niveles en el caso que la complejidad de los contextos arqueológicos lo ameritaban. Entre los componentes arqueológicos se distinguió entre: contexto funerario, contexto, hallazgo, elemento, recinto y muro.

\section{Los contextos funerarios de Purunmarca}

A continuación se presentará las características de las unidades de excavación donde se hallaron los contextos funerarios, con la descripción de estos:

\section{1.- Unidad 2:}

La unidad $\mathrm{N}^{\circ} 02$ se encuentra ubicado en el Sector Alto, emplazado sobre un terreno irregular, hacia el lado suroeste de la Unidad $\mathrm{N}^{\circ} 03$ y hacia el lado norte de la Unidad $\mathrm{N}^{\circ} 06$. Está conformada por una trinchera de $10.0 \mathrm{~m}$ de largo (NE-SW) por $2.00 \mathrm{~m}$ de ancho (NW-SE), con la cota principal a 3943 msnm (esquina NE). La secuencia estratigráfica identificada es la siguiente:

\section{Capa Superficial.}

Esta capa presenta dos colores: verde por la vegetación propia de la zona, la cual al retirarla se observa una tierra arcillosa de color marrón, posee una consistencia semicompacta y una textura gruesa. Se constituye por el $60 \%$ de vegetación natural (pasto y gramíneas) y el $40 \%$ de tierra arcillosa; se observó inclusiones frecuentes de piedras canteadas de $0.15 \mathrm{~m}$. a $0.25 \mathrm{~m}$. de diámetro de largo e inclusiones ocasionales de estiércol de ganado vacuno. Los componentes culturales que presenta esta capa es poca fragmentaria cerámica. A nivel superficial se logró identificar el muro $\mathrm{N}^{\circ} 01$ ubicado cerca de la esquina noreste y el muro $\mathrm{N}^{\circ} 02$ se ubica en la parte central del lado noreste de la unidad. 


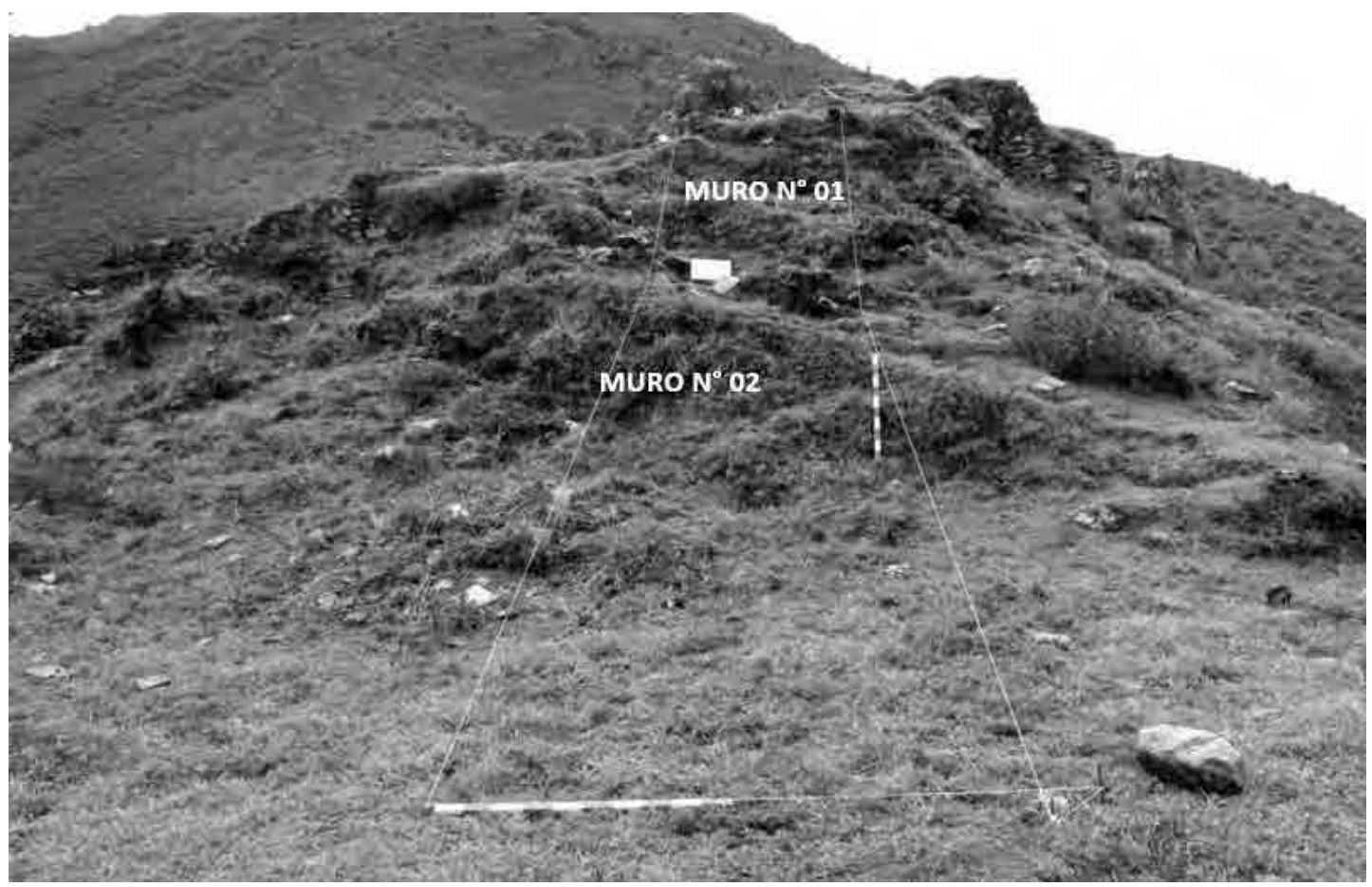

Figura 7: Vista panorámica de capa superficial, obsérvese el desnivel del terreno.

\section{Capa A.}

Presenta un color marrón oscuro, posee una consistencia semicompacta y una textura gruesa. Se constituye por el $40 \%$ de tierra arcillosa, $40 \%$ de piedras trabajadas de 0.20 m. a 0,35 m. de largo colapsadas de los muros y el $20 \%$ de raíces. Los componentes culturales que presenta esta capa son algunos fragmentos de cerámica y material óseo. La capa A corresponde al derrumbe de los muros. En esta capa se registraron el contexto $\mathrm{N}^{\circ} 01$ conformado por un conglomerado de huesos, el hallazgo $\mathrm{N}^{\circ} 01$ constituido por una conopa de forma de maíz y el hallazgo $\mathrm{N}^{\circ} 02$ formado por un instrumento textil.

Contexto 1: El contexto 1 se ubica a $0.40 \mathrm{~m}$ hacia el lado noroeste del límite de la Unidad de excavación (lado sureste), a $0.20 \mathrm{~m}$ de distancia del muro 2 hacia el lado suroeste y a $0.70 \mathrm{~m}$ de profundidad teniendo como referencia la cabecera actual de dicha estructura. Este contexto se encuentra asociado a la esquina del muro 2 (lado sureste), ya que algunos elementos se encuentran apoyados en su paramento. Este contexto fue recuperado dentro de la Capa A (derrumbe). El contexto desde una vista en planta adquiere una forma ovalada, la cual mide $1.20 \mathrm{~m}$ de largo (NW-SE), $0.60 \mathrm{~m}$ de ancho y $0.35 \mathrm{~m}$ de profundidad; y está conformado por un conjunto de óseos humanos los cuales no poseen ninguna disposición. Hacia el lado norte se identificó la mayoría de huesos largos completamente desarticulados (fémur, peroné, cúbito, etc.), huesos cortos de la mano y del pie, costillas y vértebras fragmentadas; hacia el lado sur se registró el coxis derecho, costillas, huesos largos y otros. No se identificó en campo ningún elemento asociado. El estado de conservación es regular, los restos óseos se encuentran afectados principalmente por la humedad. Probablemente este contexto haya conformado un contexto funerario el cual debió ubicarse dentro del recinto $\mathrm{N}^{\circ} 01$, lamentablemente fue totalmente alterado por derrumbe. 


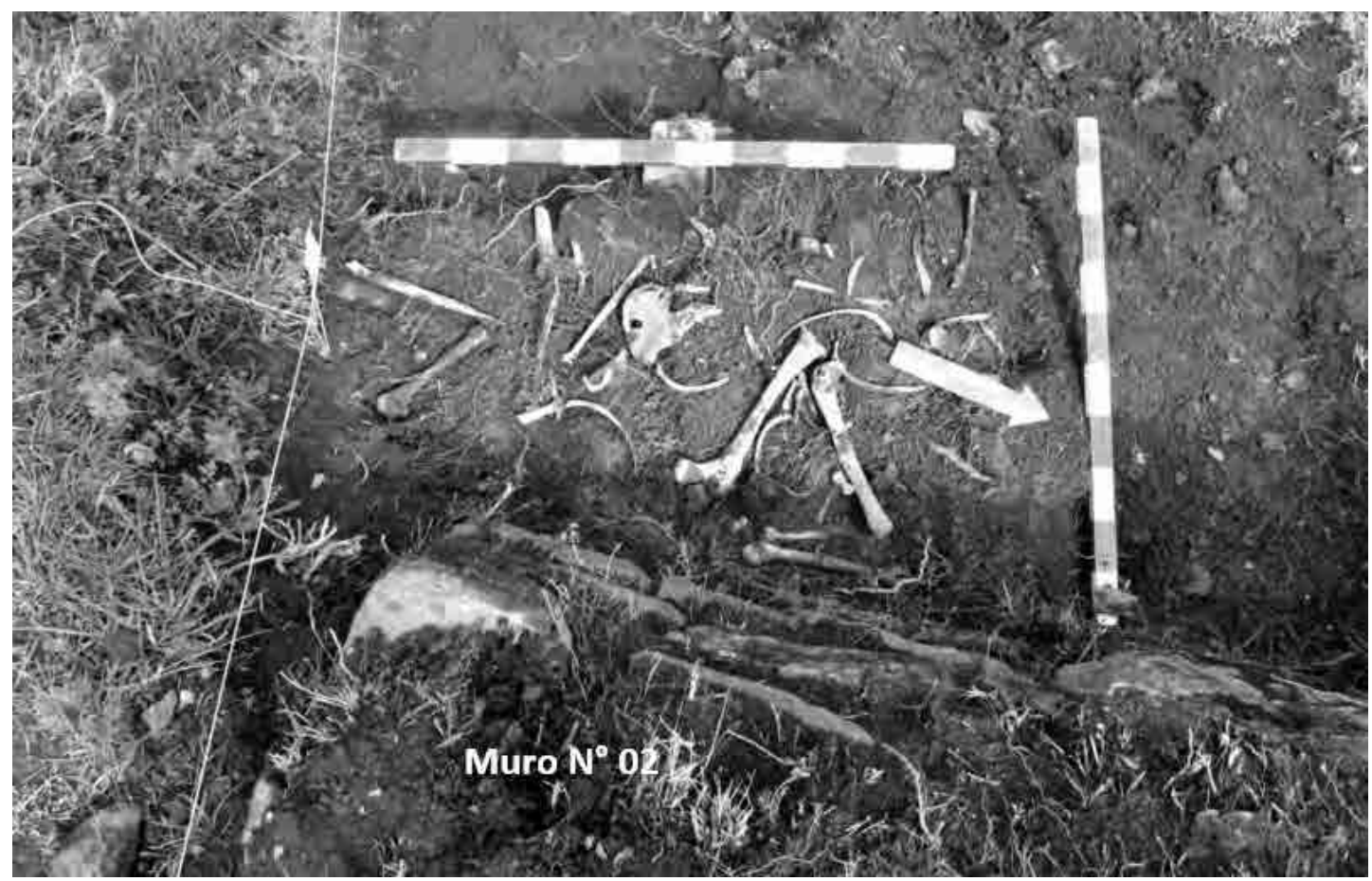

Figura 8: Según la vista en planta se observa el detalle del contexto $N^{\circ} 01$.

Hallazgo $\mathrm{N}^{\circ}$ 01: Se ubicó a $0.80 \mathrm{~m}$. hacia el lado oeste del muro $\mathrm{N}^{\circ} 02$ y a $0.40 \mathrm{~m}$. hacia el lado sur del límite de excavación (lado suroeste). Está compuesto por un objeto lítico en forma de una mazorca de maíz (conopa).

Hallazgo N02: Se ubicó hacia el lado suroeste de la unidad, a $0.25 \mathrm{~m}$. al SW del muro $\mathrm{N}^{\circ} 03$ y a 1.0 m. al SW del límite de la excavación (lado oeste). Está conformado por un artefacto óseo (cuerno de cérvido) con incisiones lineales y geométricas pequeñas y la punta pulida. Fue utilizado como instrumento textil, utilizado para unir la trama y la urdimbre en el proceso del tejido.
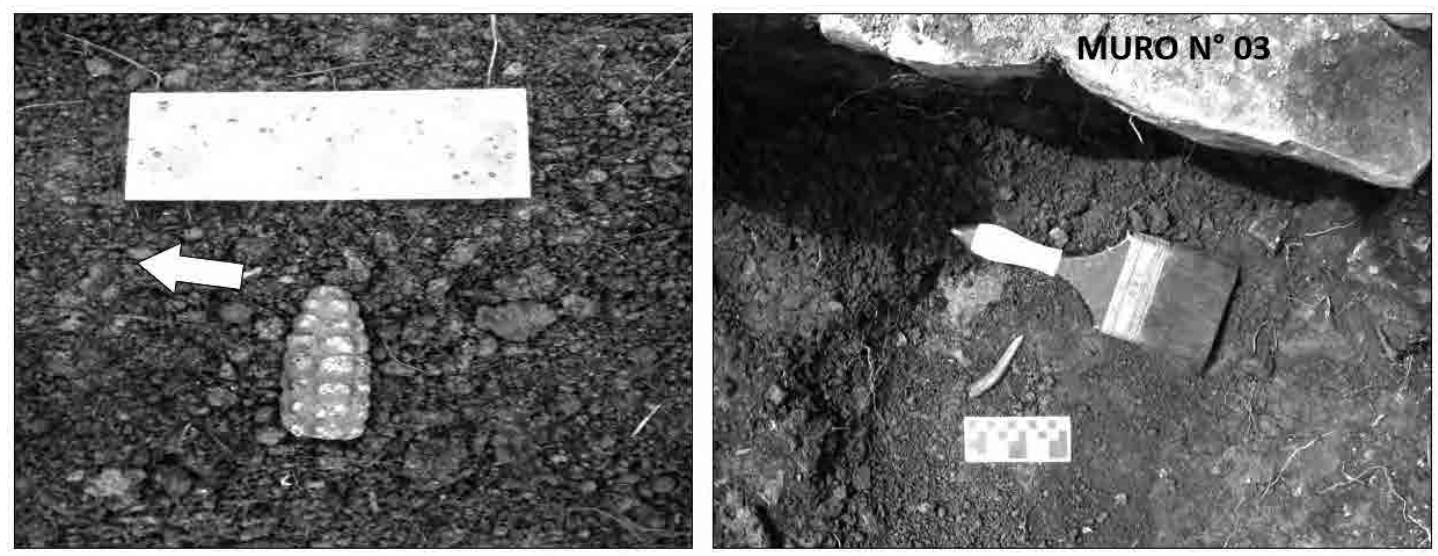

Figura 9 (izquierda): Vista de detalle del hallazgo $N^{\circ} 01$, conformado por una conopa. Figura 10 (derecha): Vista de detalle del hallazgo $N^{\circ} 02$, conformado por un cuerno de cérvido. 


\section{Piso Empedrado $n^{\circ} 01$}

Se ubica en el lado suroeste de la unidad, en la parte baja y plana (plaza), elaborado con piedras planas de forma irregular. El piso presenta un regular estado de conservación. El piso fue elaborado sobre un espacio abierto asociado a recintos de planta rectangular.

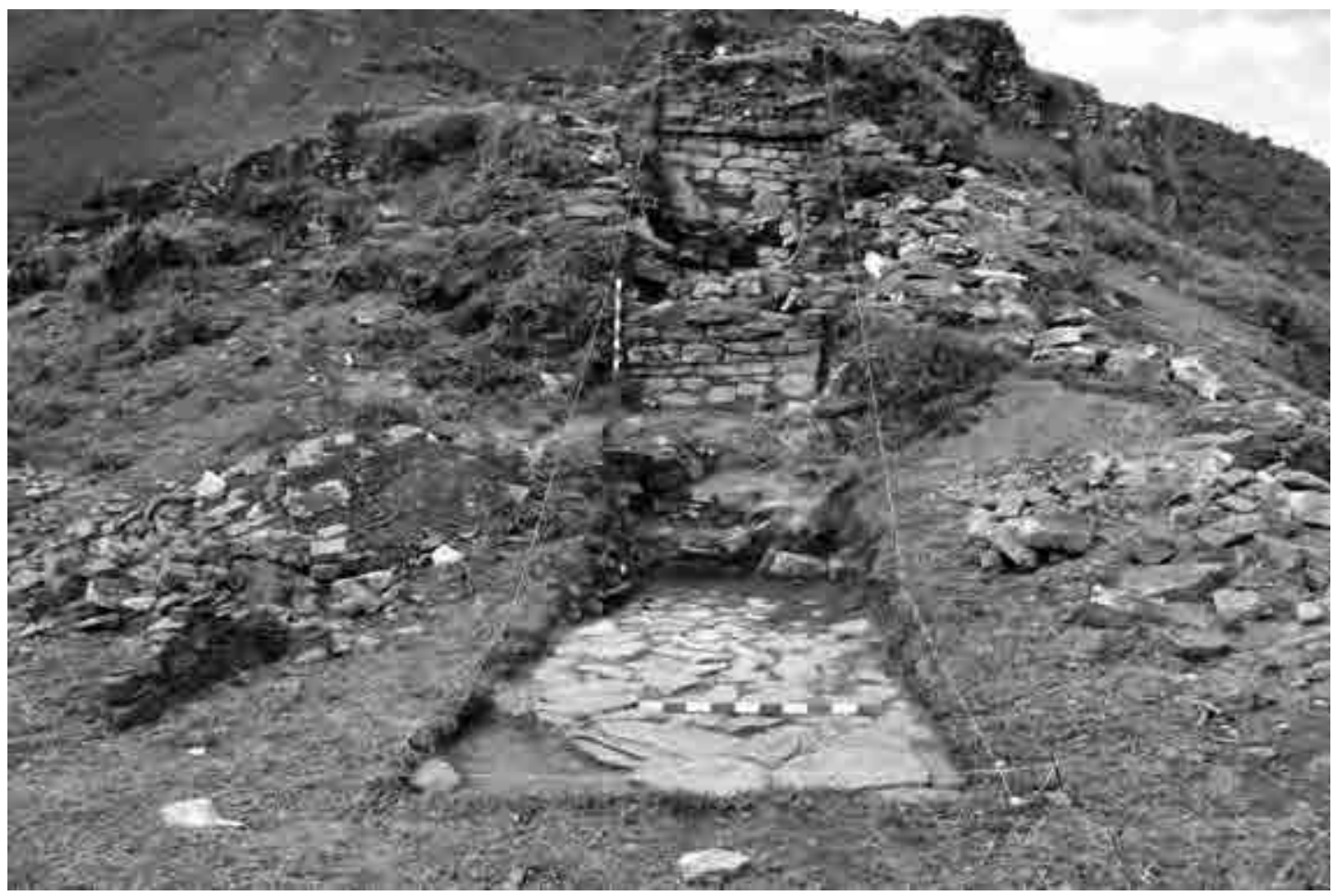

Figura 11: vista panorámica del piso empedrado identificado al suroeste de la unidad.

\section{Capa B}

Se caracteriza por ser de color marrón oscuro, posee una consistencia semicompacta y una textura gruesa. Los componentes naturales se constituyen por el 65\% de piedras trabajadas (caída de

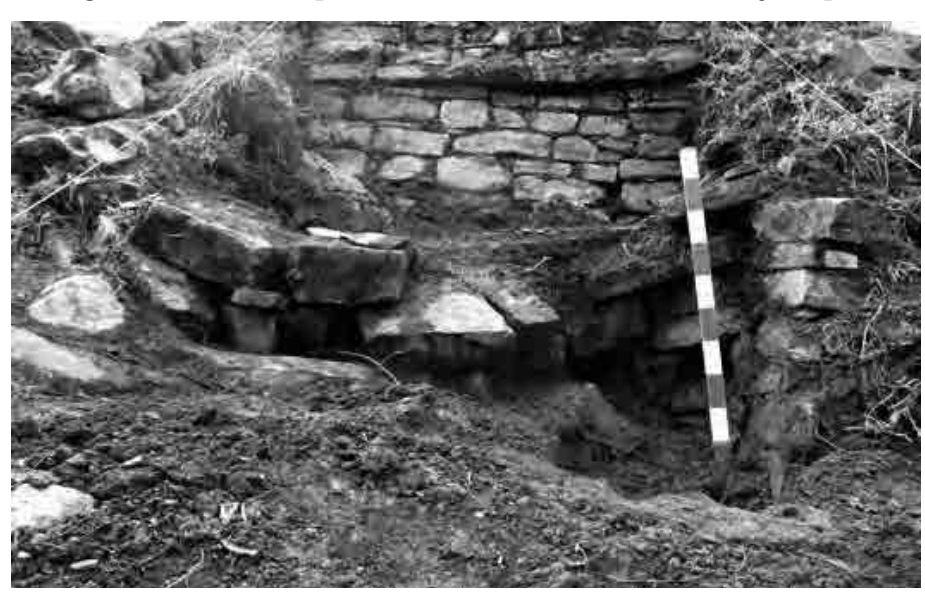

muros) y el $35 \%$ de tierra arcillosa. Entre los componentes culturales se recuperó material cerámico y óseo (inclusiones ocasionales). Esta capa constituye el primer derrumbe, conformado por los elementos constructivos de los muros que constituyen el recinto $\mathrm{N}^{\circ} 01$. Posteriormente fue cubierto con el segundo nivel de derrumbe: la capa A.

Figura 12: Vista de detalle de la Capa B. 
Contexto Funerario 1: Recuperado dentro de la cámara funeraria ubicada al sureste del recinto $\mathrm{N}^{\circ} 01$.

- Estructura funeraria: Es una cámara de planta indefinida, pues dicha estructura sobresale del límite de la unidad. Mide $0.54 \mathrm{~m}$ de largo, $0.44 \mathrm{~m}$ de ancho máximo, $0.36 \mathrm{~m}$ de ancho mínimo y $0.55 \mathrm{~m}$ de altura conservada. Fue construida con piedras trabajadas de 0.20 a $0.35 \mathrm{~m}$ en un $60 \%$ y por piedras de $0.10 \mathrm{~m}$ a $0.15 \mathrm{~m}$ en un $40 \%$; asimismo, posee una vano de acceso de planta rectangular de $0.55 \mathrm{~m}$ de altura, $0.40 \mathrm{~m}$ de ancho y $0.20 \mathrm{~m}$ de grosor, orientado al noreste.

- Individuo: El conglomerado de óseos humanos se sitúan en el extremo sur de la cámara, no se identificó ninguna disposición aparente ni elementos asociados. Se logró registrar huesos largos (húmero, tibia, peroné, etc.), huesos cortos (falanges, vértebras, etc.), observándose que el entierro estaba constituido por varios individuos, el contexto se encuentra completamente disturbado.

- Asociaciones: No presentaba.

El contexto funerario $\mathrm{N}^{\circ} 01$ corresponde a un entierro múltiple, posiblemente de individuos adultos.

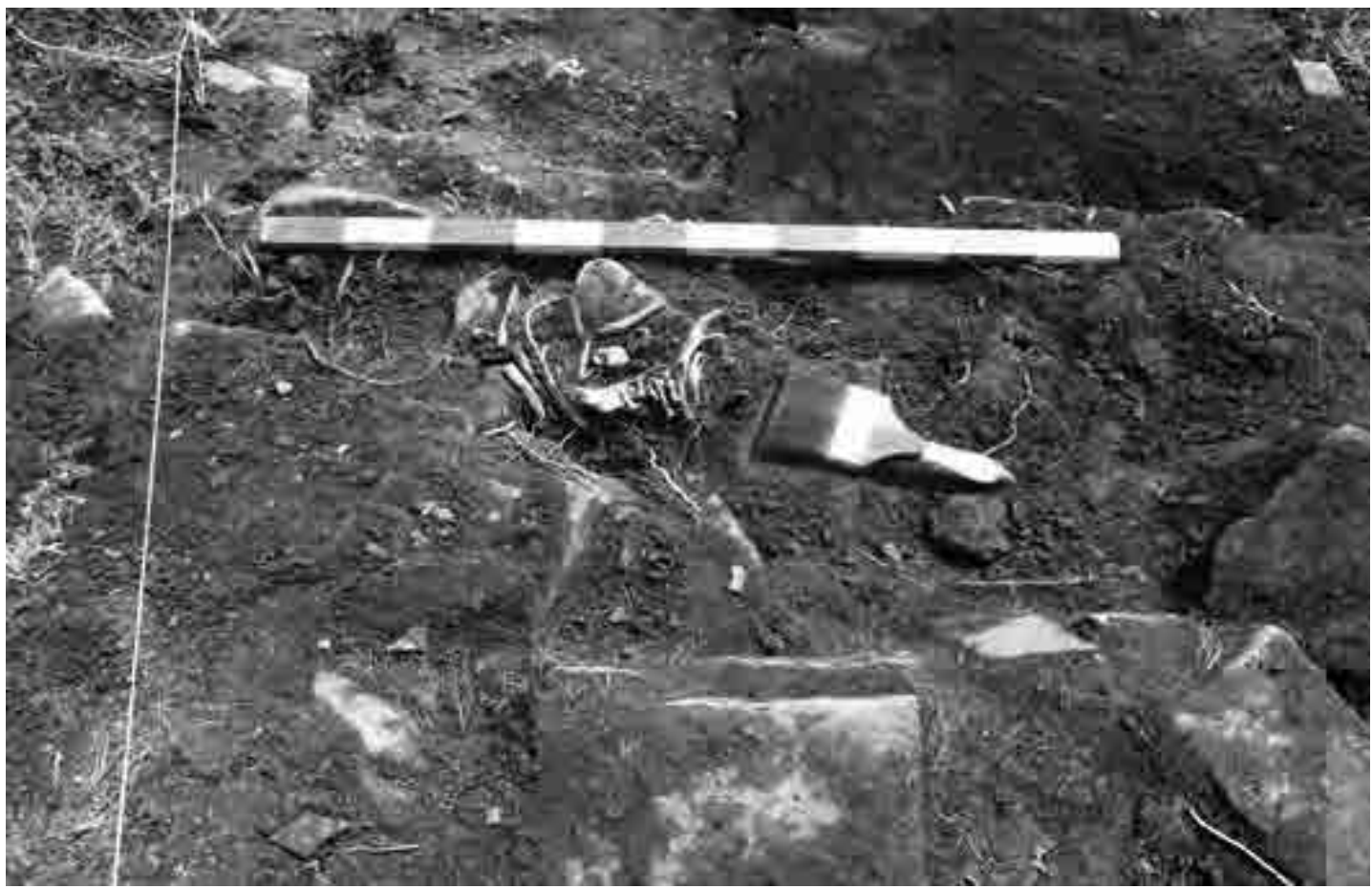

Figura 13: vista de planta del contexto funerario $N^{\circ} 01$.

Contexto Funerario 2: Se halla situado hacia el lado suroeste del recinto $\mathrm{N}^{\circ} 01$, dentro de una matriz.

- Estructura funeraria: Está compuesta por una pequeña matriz de planta rectangular, conformado por piedras rectangulares de $0.50 \mathrm{~m}$ a $0.70 \mathrm{~m}$ de largo, midiendo en su totalidad $0.60 \mathrm{~m}$ de largo (N-S), $0.50 \mathrm{~m}$ de ancho (W-E) y $0.12 \mathrm{~m}$ de altura. 


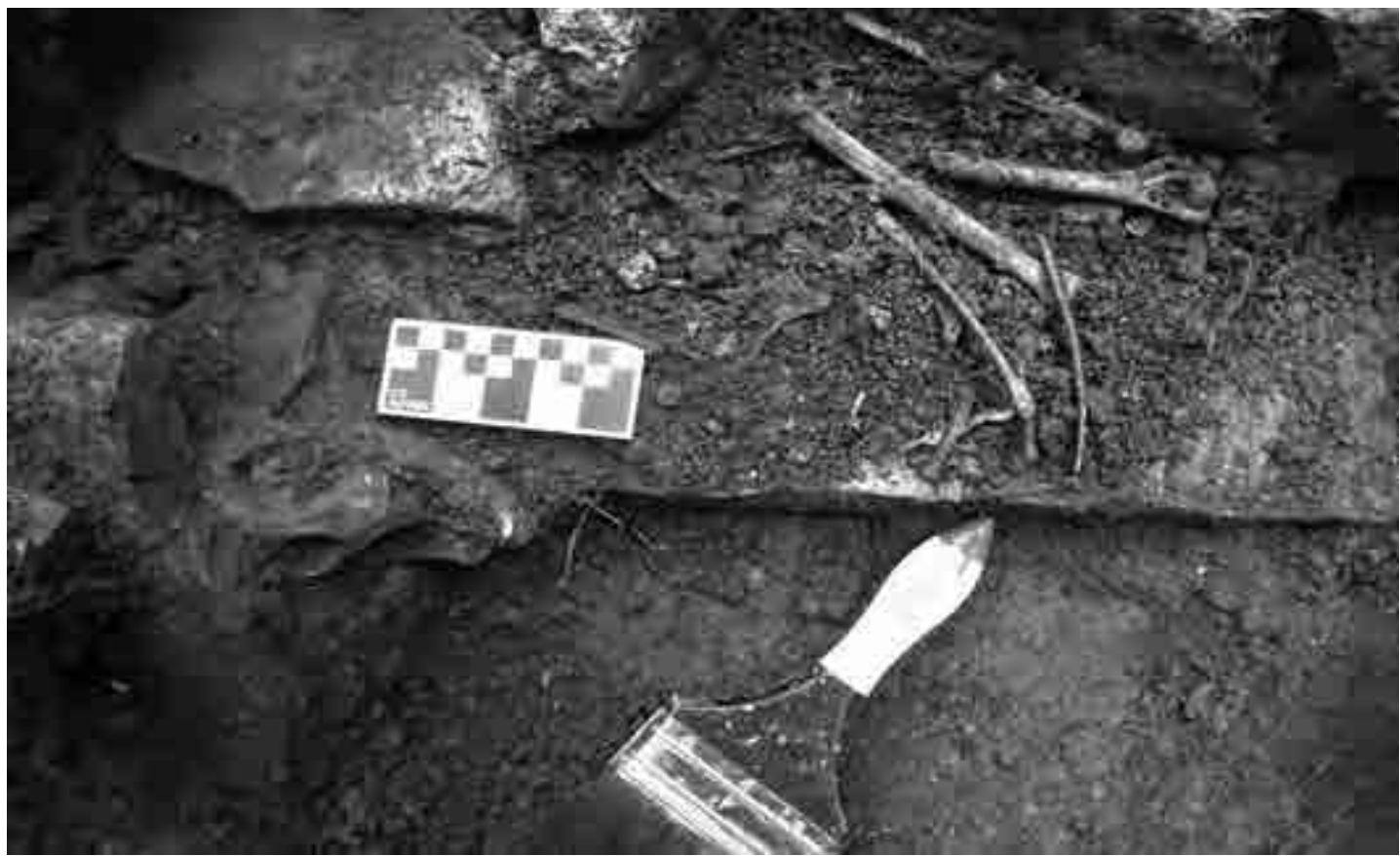

Figura 14: vista de planta del contexto funerario $n^{\circ} 02$, correspondiente a un individuo animal.

- Individuo: corresponde a un individuo animal posiblemente un perro, el cual se orienta de norte a sur y el cráneo se ubica hacia el lado sureste de la matriz y el cuerpo presenta una disposición anatómica natural. El individuo se encuentra incompleto y su estado de conservación es regular debidoaque el cráneo se encuentra fragmentado.

- Asociaciones: No presentaba.

Hallazgo 3: Artefacto lítico (canto rodado trabajado), ubicado dentro de la capa B, en la esquina suroeste del recinto 1 , exactamente a $0.40 \mathrm{~m}$ hacia el sureste del muro $\mathrm{N}^{\circ} 02$ y a $0.30 \mathrm{~m}$ hacia el suroeste del muro oeste de la cámara del contexto funerario 1.
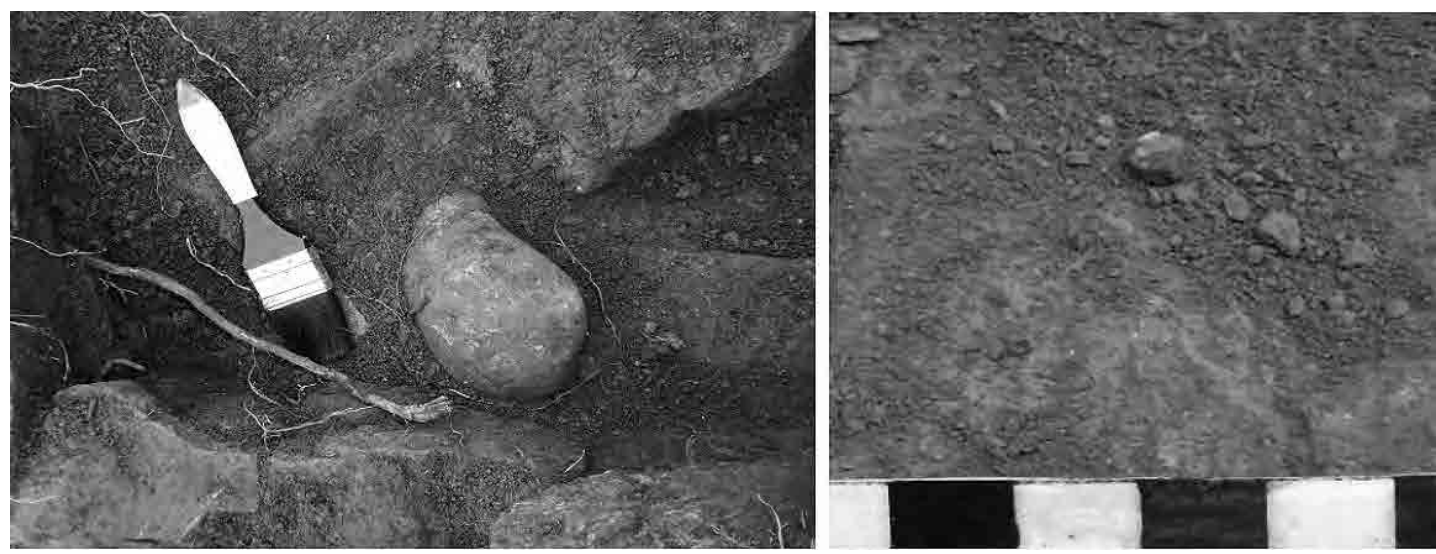

Figura 15 (izquierda): vista de planta del hallazgo $n^{\circ} 03$, ubicado dentro del recinto $N^{\circ} 01$. Figura 16 (derecha) Vista de detalle de la cuenta registrada como el Hallazgo $N^{\circ} 04$. 


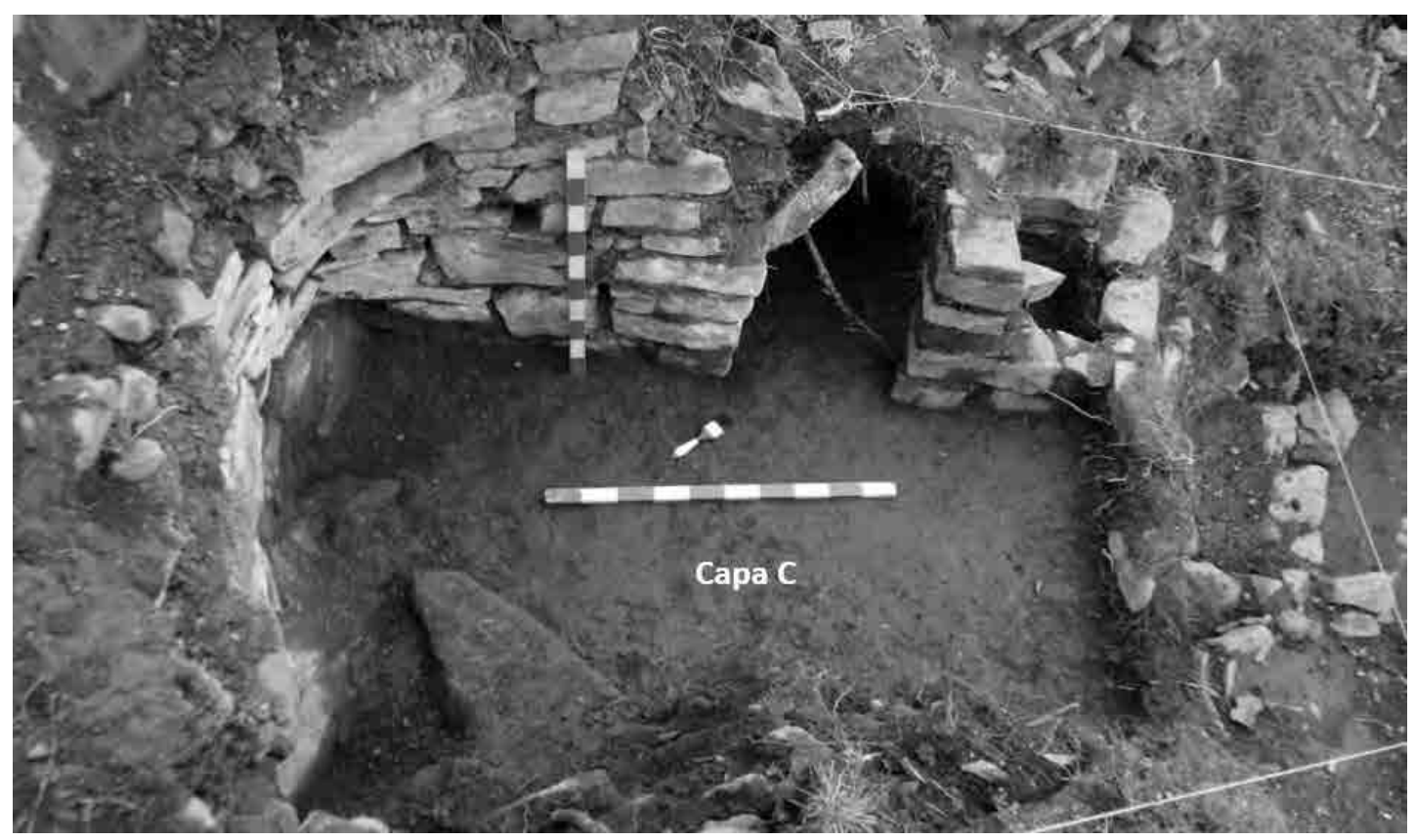

Figura 17: Vista panorámica de la capa C.

\section{CAPA C}

Esta capa fue identificada dentro del recinto $\mathrm{N}^{\circ} 01$ y de la cámara funeraria $\mathrm{N}^{\circ} 01$. Se caracteriza por presentar color marrón oscuro, consistencia compacta y textura fina; se conforma por el $80 \%$ de tierra arcillosa y el $20 \%$ de grava fina. Ocasionalmente se observa inclusiones de grava gruesa. Respecto al material cultural, se registró material cerámico y óseo en menores cantidades. Dentro de esta capa se recuperó el Hallazgo $\mathrm{N}^{\circ} 04$.

Hallazgo 4: Corresponde a una cuenta de Spondylus, ubicada a $0.40 \mathrm{~m}$ de distancia hacia el lado noreste del muro 2 y a $0.30 \mathrm{~m}$ de distancia hacia el lado noroeste del muro 7.

\section{APISONADO N ${ }^{\circ} 01$}

Registrado dentro del recinto $\mathrm{N}^{\circ} 1$, de color marrón claro, consistencia compacta y textura fina. Está constituida por el $80 \%$ de tierra arcillosa y el $20 \%$ de grava fina, ocasionalmente se observa inclusiones de grava gruesa. Tiene $0.08 \mathrm{~m}$ de grosor, fue utilizado como un nivel de uso dentro del recinto $\mathrm{N}^{\circ} 1$.

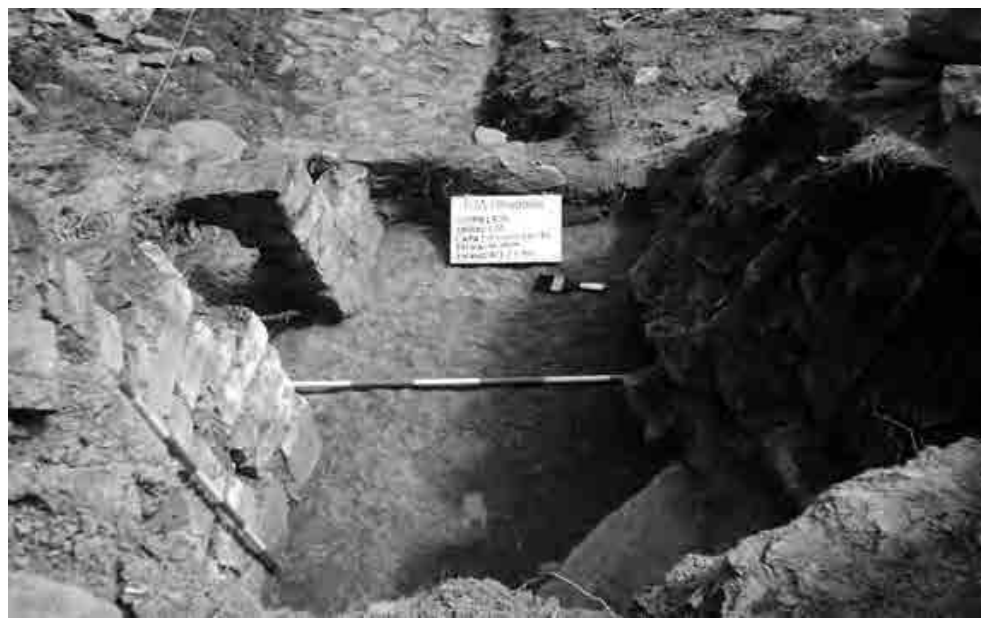

Figura 18: Vista panorámica del Apisonado $N^{\circ} 01$, ubicado dentro del recinto $N^{\circ} 01$. 


\section{2.- UNIDAD 03:}

La Unidad 3, de 8x8m se ubica en el sector alto, fue dividida en 4 subunidades. La subunidad I se encuentra ubicada en el extremo suroeste de la unidad, la subunidad II se sitúa en el extremo noroeste, la subunidad III se encuentra al extremo sureste y finalmente, la subunidad IV se ubica al noreste de la unidad.

\section{SUBUNIDAD I: Recinto 1}

La primera capa registrada fue la Superficial de origen natural, la cual cubre a la capa A conformada por el segundo momento de derrumbe de los Muros 5, 6, 7, 8 y 9 (Recinto 1). La capa A cubre a la capa $\mathrm{E}$ interpretado como el primer momento de derrumbe de los muros que conforman el recinto 1. La capa F está contenida por la estructura funeraria 1. La capa E cubre al apisonado 2, el cual fue colocado para nivelar la superficie de la roca madre y ser utilizado como un nivel de uso.

\section{Capa E}

Está capa fue registrada dentro del Recinto 1, ubicado en la Subunidad I. Dicha capa es de tierra arcillosa color marrón oscuro, de consistencia semicompacta y de textura gruesa; esta presenta inclusiones de piedras trabajadas colapsadas de los muros y raíces de las plantas superficiales. Se observó inclusiones moderadas de caracoles de loma. En cuanto a los componentes culturales se aprecian fragmentos de cerámica algunos con restos de hollín, y material óseo animal. Dentro de esta capa se recuperaron los Hallazgos 1, 2, 4 y 5.

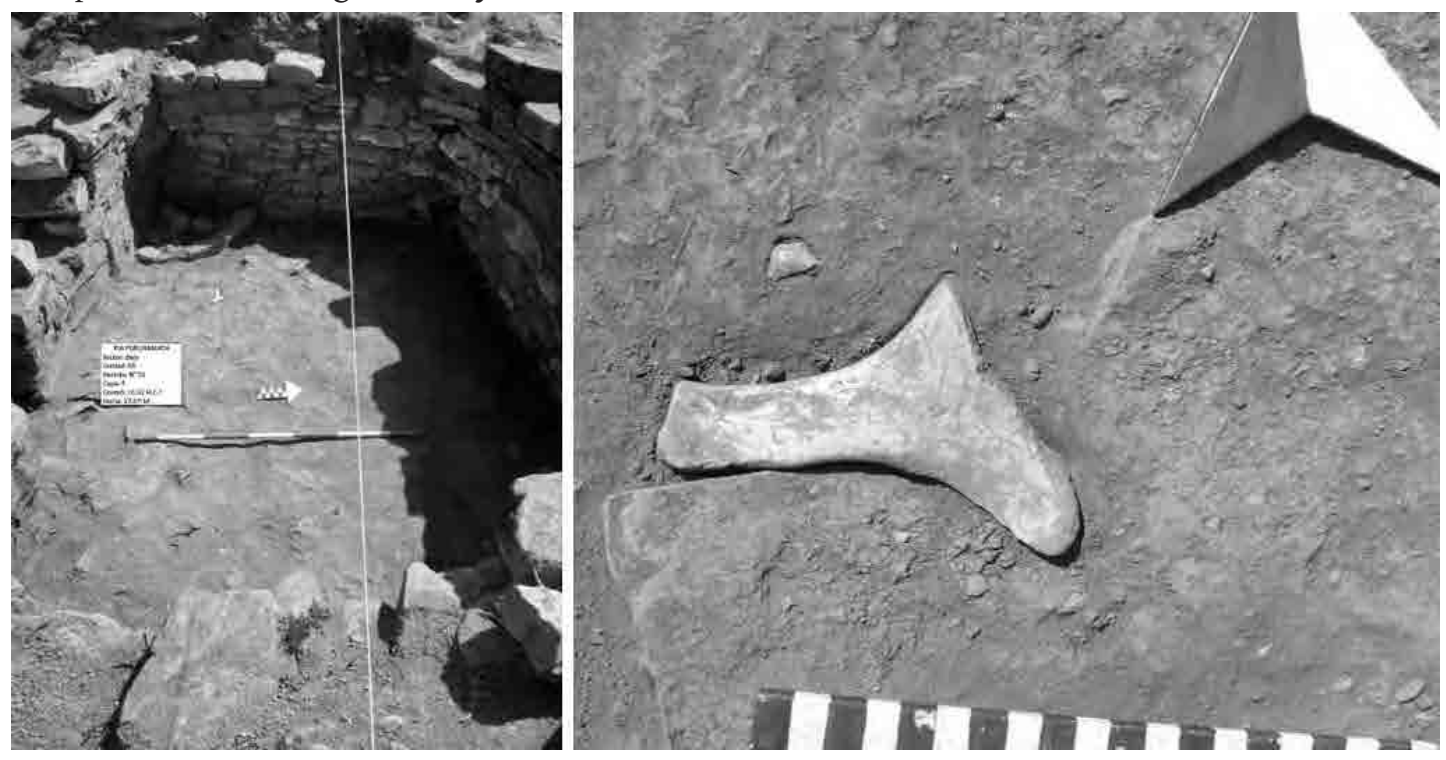

Figura 19: Vista panorámica de la capa E, registrada en el Recinto $N^{\circ} 01$ - Subunidad I. Figura 20: Vista de detalle del Hallazgo $N^{\circ} 01$ - artefacto óseo animal.

Hallazgo $\mathrm{N}^{\circ}$ 01: Es una illa elaborada a partir de un óseo de camélido.

Hallazgo $\mathrm{N}^{\circ}$ 02: Fragmento de una porra lítica.

Hallazgo $\mathrm{N}^{\circ}$ 04: Artefacto óseo el cual posiblemente fue utilizado para realizar cortes punzocortantes.

Hallazgo $\mathrm{N}^{\circ}$ 05: Artefacto óseo, similar a una espátula y cuya funcionalidad no está determinada. 
Contexto Funerario $\mathrm{N}^{\circ} 01$ : El contexto funerario $\mathrm{N}^{\circ} 01$ se ubica al suroeste del Recinto $\mathrm{N}^{\circ} 01$. Sus componentes son:

- Estructura funeraria: La estructura fue conformada por la elaboración de un muro curvo el cual se adosa al Muro $\mathrm{N}^{\circ} 09$ y al Muro $\mathrm{N}^{\circ} 08$, adquiriendo la forma de la cuarta parte de un círculo. Sus medidas no son homogéneas, hacia el lado sur mide $0.65 \mathrm{~m}$ de largo, hacia el oeste $0.58 \mathrm{~m}$ y de radio mide $0.65 \mathrm{~m}$. Fue elaborada con piedras trabajadas de $0.15 \mathrm{~m}$ a $0.22 \mathrm{~m}$ de largo y fueron unidos con mortero de arcilla gris. Esta estructura contiene a la Capa F de color marrón oscuro, de consistencia suelta y de textura fina, conformado por el $80 \%$ de tierra arcillosa y el $20 \%$ de grava fina, se observa inclusiones frecuentes de raíces.

- Individuo: Se trata de un contexto conformado por varios individuos los cuales fueron colocados dentro de la estructura, en el primer nivel se observó dos cráneos ubicados en la parte central y orientados de suroeste a noreste; los cuales fueron rodeados por diversos huesos largos, cortos, etc. En el segundo nivel se observó tres cráneos colocados hacia los lados suroeste, sureste y noreste; manteniendo la misma orientación del primer nivel. Hacia el lado noroeste se identificó la mayoría de huesos largos los cuales se apoyaban hacia el paramento interno del muro curvo de la estructura funeraria y hacia el lado oeste se encuentran las costillas y hacia los otros lados los demás huesos (costillas, falanges, etc).

- Asociaciones: En el primer nivel: Hacia el extremo noreste se ubica una piedra trapezoidal sobre la cual se recuperó un artefacto óseo de forma circular el cual mide $4 \mathrm{~cm}$ de diámetro y pose un orificio central de $1 \mathrm{~cm}$. Este artefacto es un piruro. En el segundo nivel: Continuando con la excavación se recuperó un piruro de forma circular elaborado de arcilla, el cual se encuentra fragmentado por la mitad. Asimismo, hacia el lado sureste se registró una aguja elaborada en óseo animal de buen acabado (pulido). Es importante mencionar que dentro del contexto se recuperó material óseo animal correspondiente a roedores y huesos (vértebras) de camélidos.

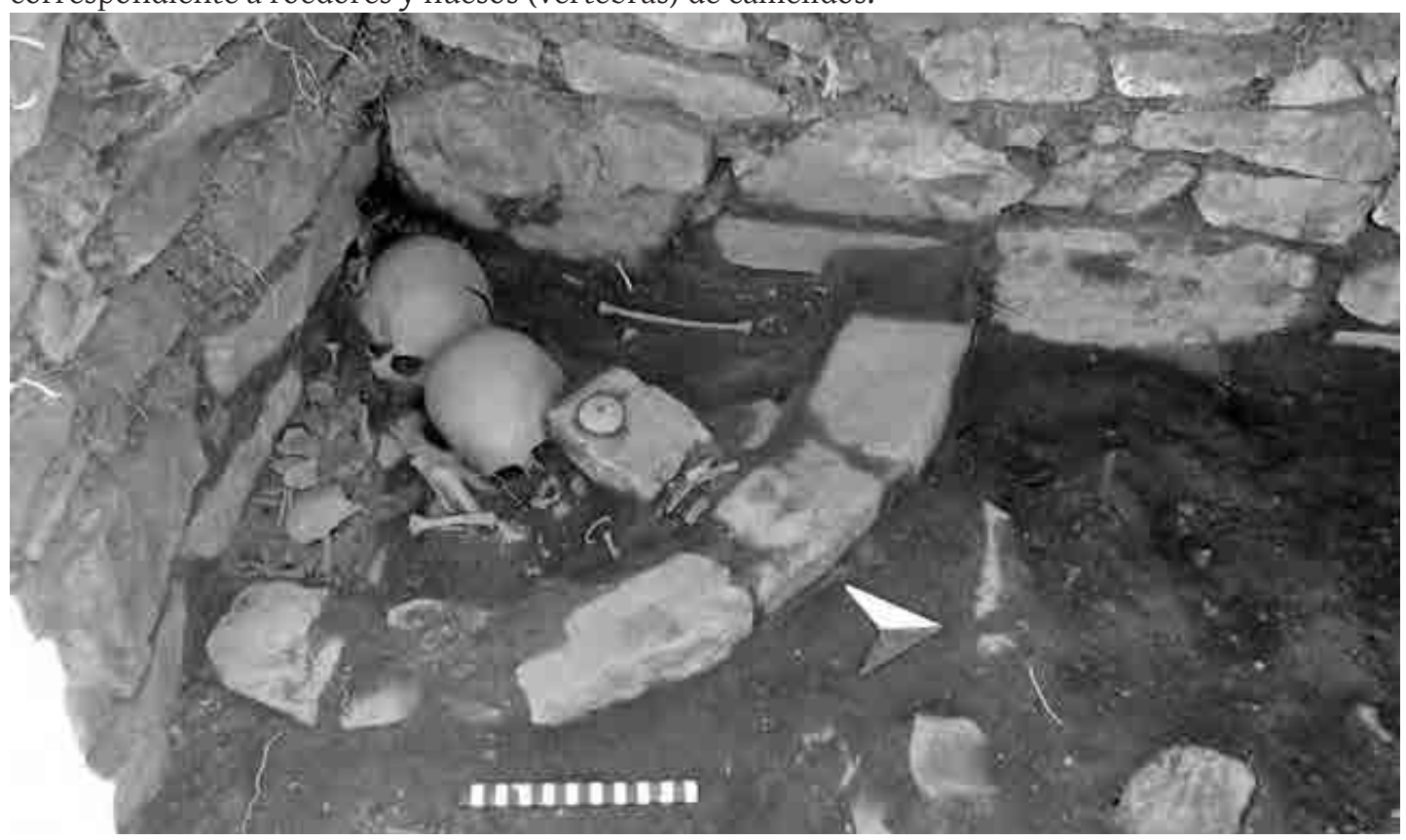

Figura 21: Vista de detalle del primer nivel del contexto funerario $N^{\circ} 01$, ubicado dentro del Recinto $N^{\circ} 01$. 


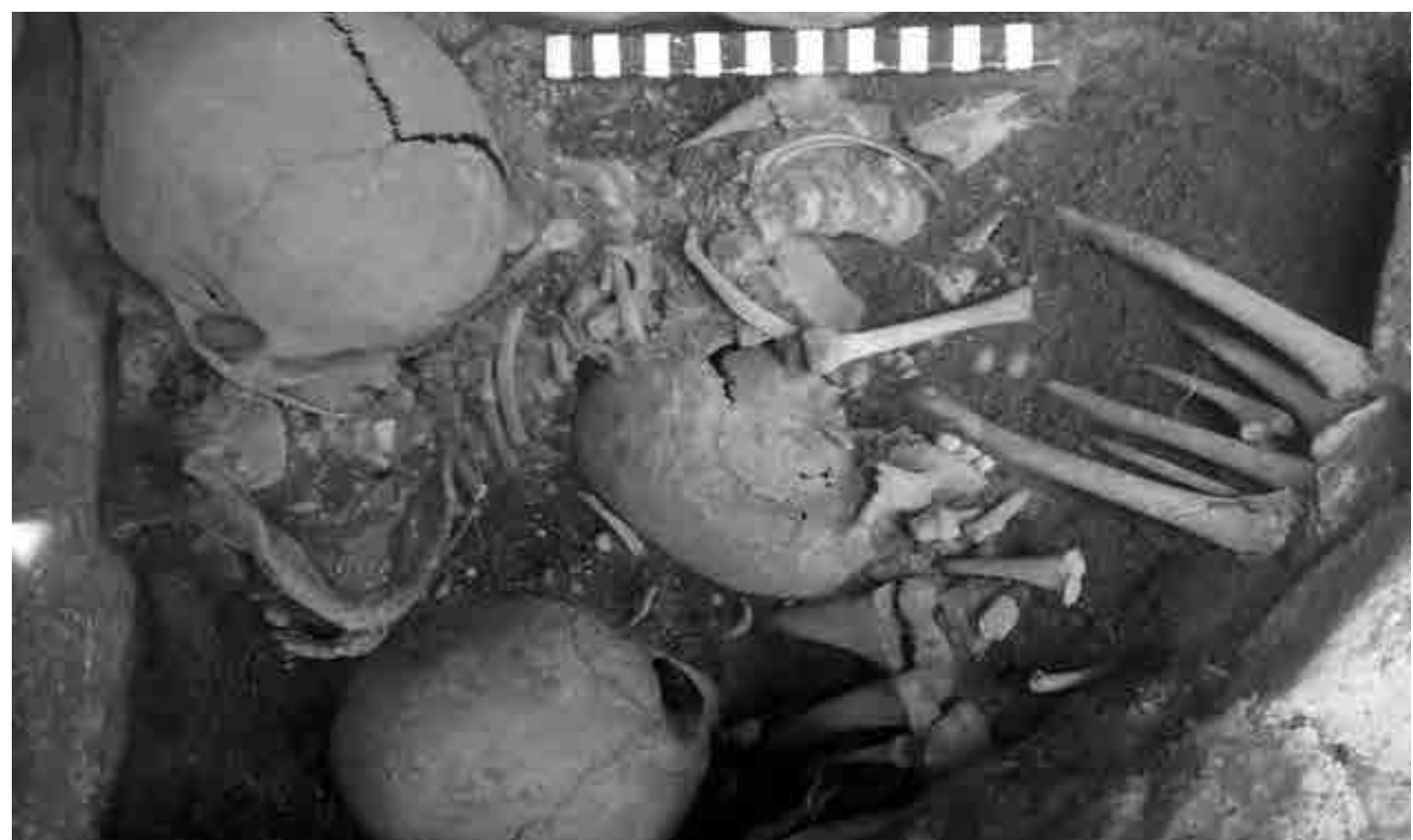

Figura 22: Vista de detalle del segundo nivel del contexto funerario $N^{\circ} 01$, ubicado dentro del Recinto $N^{\circ} 01$.

\section{Apisonado 2}

El apisonado 2 fue registrado dentro del recinto 1, el cual se ubica en la Subunidad I. Esta capa es de tierra arcillosa de color marrón y grava fina, de consistencia semicompacta y de textura fina. Este apisonado fue cubierto por la Capa $\mathrm{E}$ y fue colocado para nivelar la superficie irregular de la roca madre. Tiene $0.02 \mathrm{~m}$ de grosor.

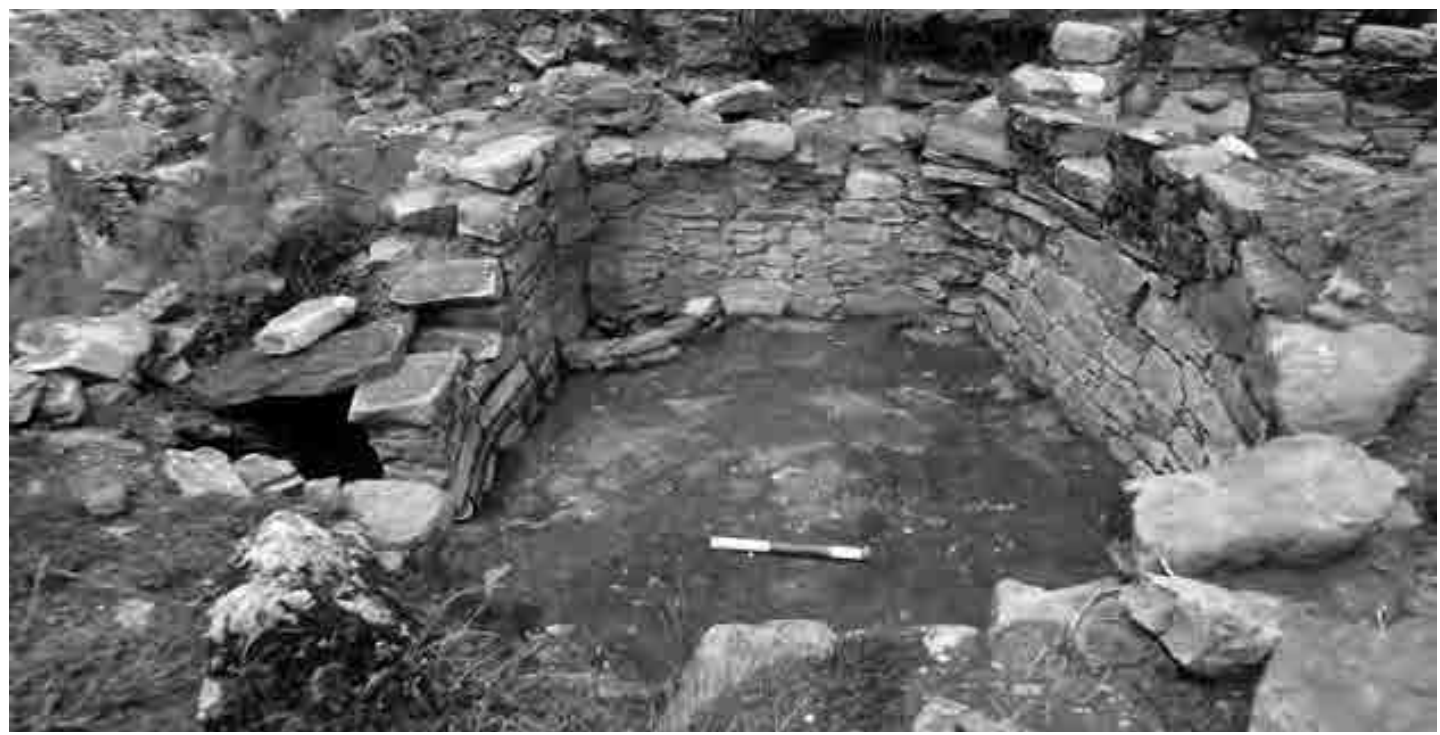

Figura 23: Vista panorámica del Apisonado 2, registrado dentro del Recinto 1 - Subunidad I. 
Contexto 1: El contexto se ubica hacia el extremo noroeste del recinto 1 y fue colocado en la base del Muro 5. Fue recuperado dentro del Apisonado $\mathrm{N}^{\circ} 02$. El Contexto 1 está constituido por un conglomerado de restos óseos de origen animal y de ceniza, los cuales adquieren una forma ovalada que se orienta de suroeste a noreste. El área mide $0.34 \mathrm{~m}$ de largo, $0.14 \mathrm{~m}$ de ancho y $0.12 \mathrm{~m}$ de profundidad. Es importante mencionar que algunos restos óseos presentan evidencias de quema, asimismo, no se observa ninguna disposición de sus elementos (huesos largos, vértebras, costillas, dientes sueltos, etc.). El contexto 1 fue colocado como una ofrenda constructiva.

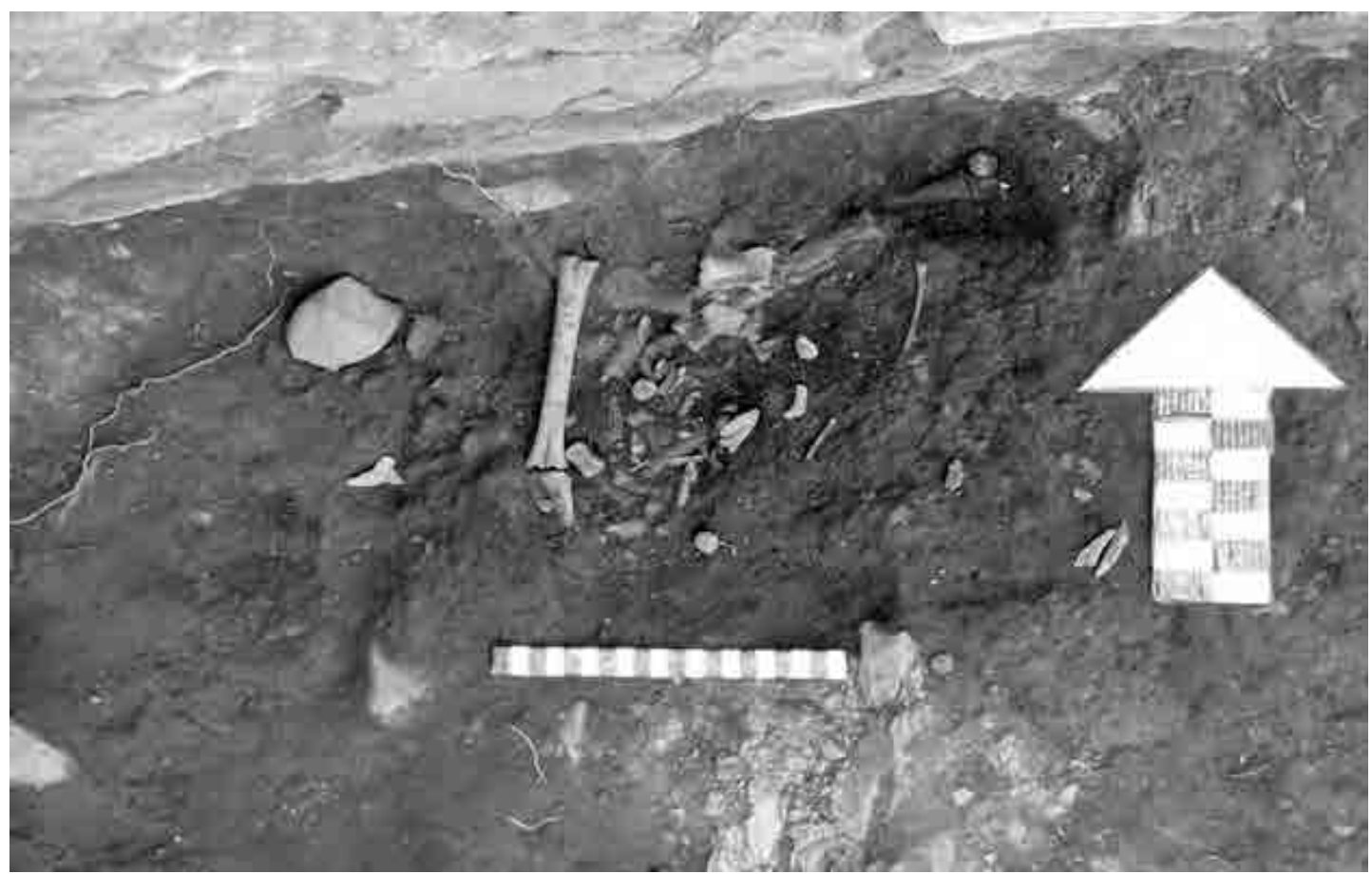

Figura 24: Vista de detalle del Contexto $N^{\circ} 01$, ubicado dentro del Recinto 1.

\section{Recinto $\mathrm{N}^{\circ} 03$}

Este recinto se ubica en el extremo suroeste de la Subunidad I, hacia el lado oeste del Recinto 1. Durante el proceso de excavación se retiró la capa superficial y la capa A (derrumbe). Finalmente, se logró exponer el Apisonado 3. Es importante mencionar que el Recinto 3 no fue expuesto en su totalidad ya que excede a los límites de nuestra unidad.

Hallazgo 6: Se trata de un objeto circular de metal, el cual debió formar parte de un arete o de un collar.

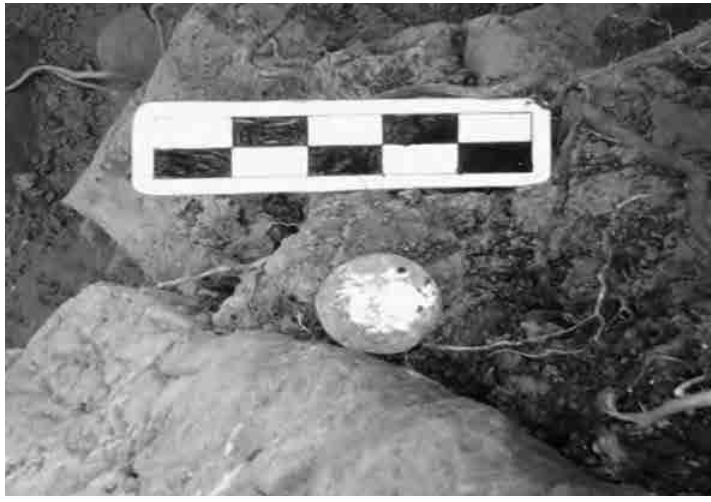

Figura 25: Vista de detalle del Hallazgo $N^{\circ} 06$ conformado por un objeto metálico. 


\section{Apisonado 3}

Fue registrado dentro del Recinto 3, el cual se ubica en la Subunidad I. Es de tierra arcillosa, de color marrón, de consistencia semicompacta y de textura fina, de $0.01 \mathrm{~m}$ de grosor.

Contexto Funerario Animal 1: Corresponde a una cabra la cual se orienta de noreste a suroeste, presenta una posición extendida de $1.20 \mathrm{~m}$ de largo y $1.20 \mathrm{~m}$ de ancho. Las osamentas están incompletas, se encontró un cráneo, 2 mandíbulas, 20 costillas, 28 vertebras, 1 sacro y 22 huesos pequeños. En asociaciones directas se identificó restos óseos de roedor, conformados por 24 huesos los cuales estaban dispersos en toda el área que ocupaba las osamentas de la cabra. Indirectamente estuvo asociado a cinco artefactos óseos hechos a partir de escápulas. Este contexto fue recuperado sobre el Apisonado $\mathrm{N}^{\circ} 03$ y fue cubierto por la capa A, data del Periodo de Transición Tawantinsuyu - colonial.

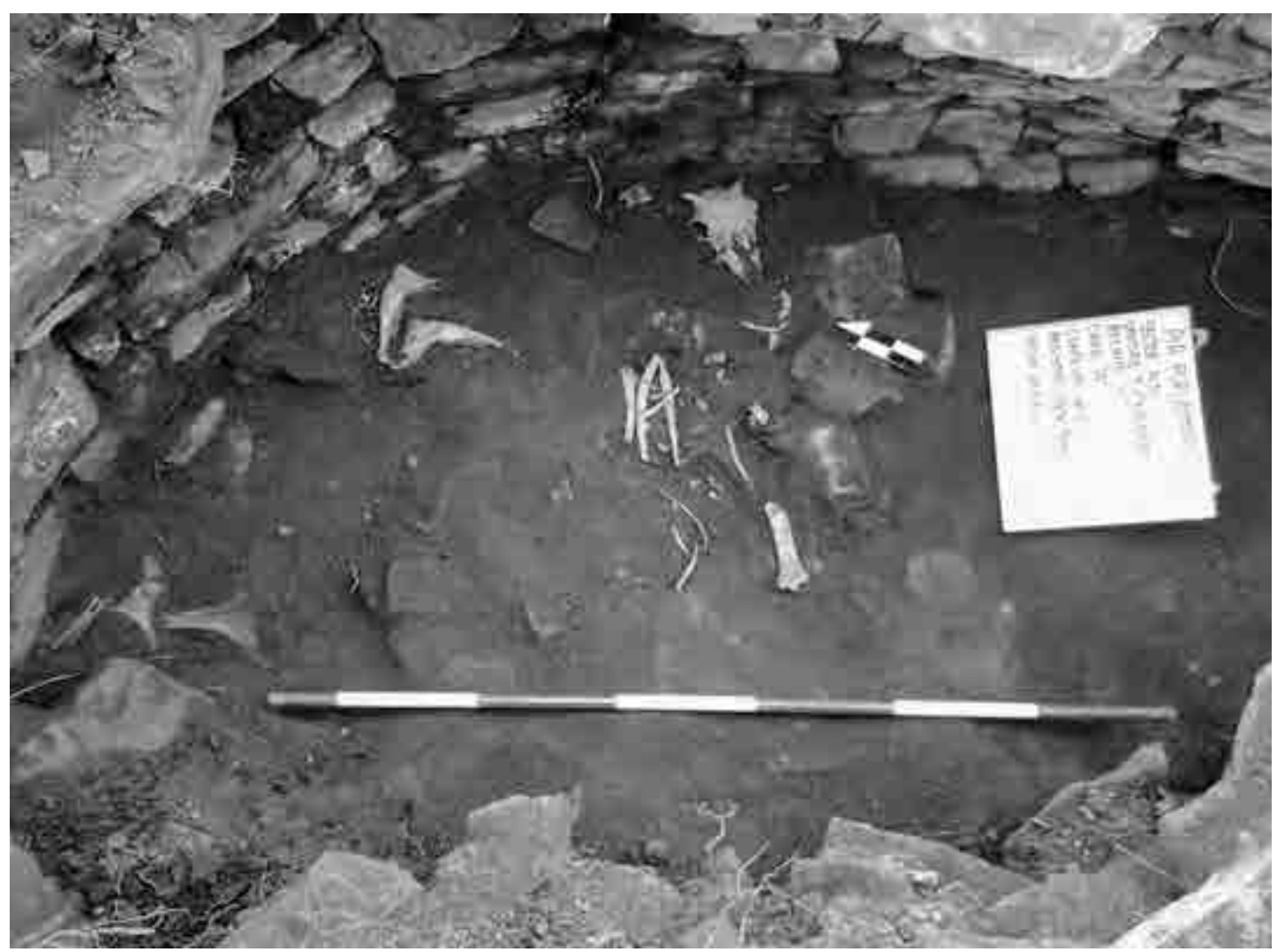

Figura 26: Vista panorámica del Contexto Animal $N^{\circ} 01$.

Contexto 2: Se sitúa hacia el extremo noroeste del recinto 3, fue colocado sobre el Apisonado 2 y está cubierto por la Capa A. Está asociado al Muro 10 (paramento interno). El contexto está conformado por escápulas, una moneda y una aguja las cuales abarcan un espacio de forma ovalada orientado de oeste a este. El área mide $0.35 \mathrm{~m}$ de largo, $0.22 \mathrm{~m}$ de ancho y $4 \mathrm{~cm}$ de profundidad. Los elementos muestran la siguiente disposición: hacia el extremo sureste se encuentra una aguja elaborada en óseo animal, las cinco escápulas abarcan toda el área del contexto, y hacia el lado suroeste se identificó un objeto de metal de forma circular. El contexto 2 fue colocado como una ofrenda. 


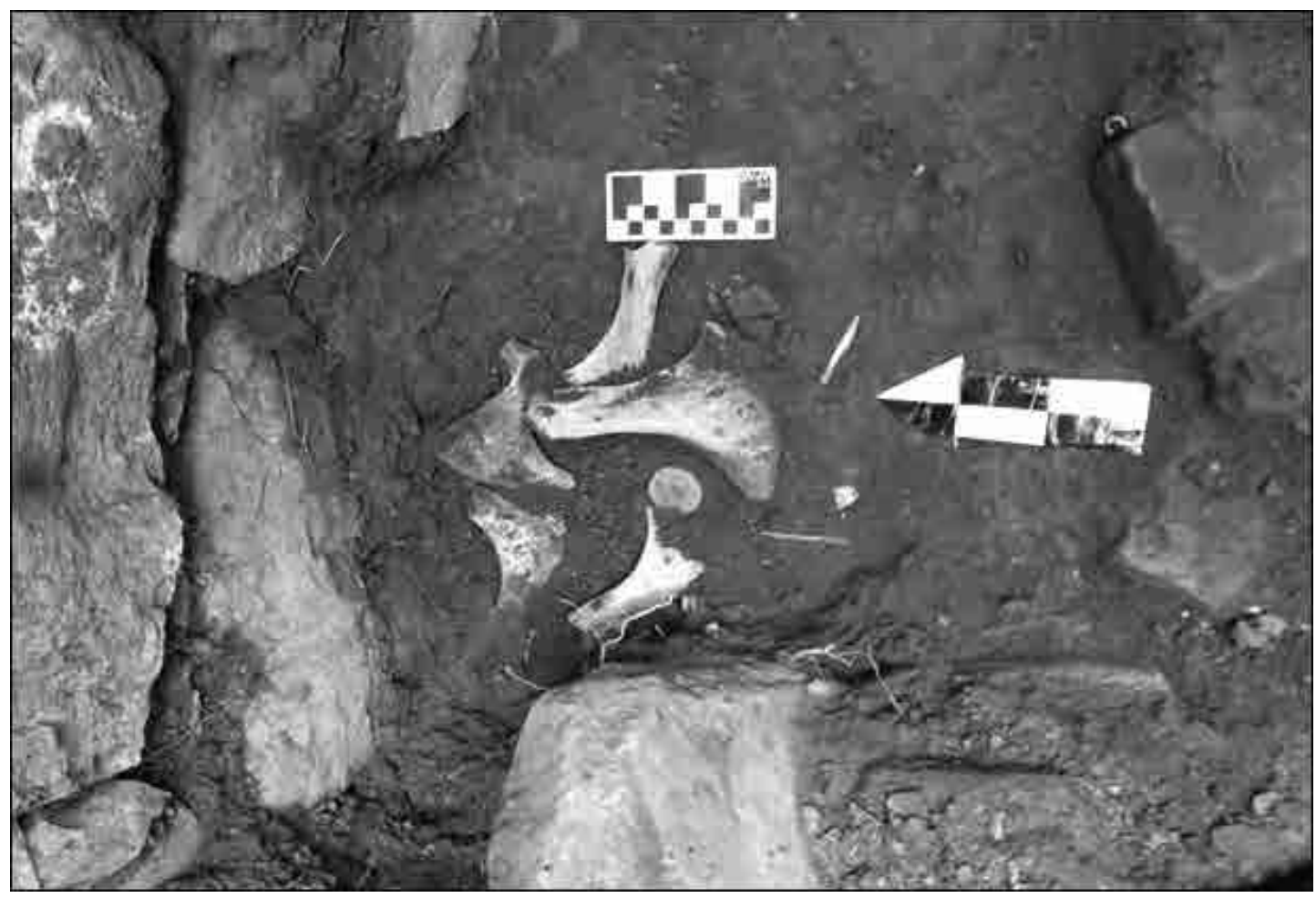

Figura 27: Vista de detalle del Contexto $N^{\circ} 02$, conformado por un conjunto de escápulas.

\section{3.- UNIDAD 7}

La unidad $\mathrm{N}^{\circ} 07$ se encuentra situada en el sector medio del sitio, emplazada sobre un terreno irregular. Se ubica al suroeste de la unidad $4 \mathrm{y}$ al norte de la unidad 9. Es una trinchera de $10.0 \mathrm{~m}$ de largo $(\mathrm{N}-\mathrm{S})$ por $2.0 \mathrm{~m}$ de ancho (W-E). Por las estructuras arquitectónicas halladas en su interior fue divida en dos subunidades: I ubicada al norte y la II ubicada al sur. La secuencia estratigráfica identificada en esta unidad es la siguiente:

\section{Capa Superficial}

Esta capa es de color verde por la vegetación típica de la zona, la cual al ser retirada adquiere un color marrón por la tierra arcillosa. Posee consistencia semicompacta y textura gruesa. Se constituye por el 50\% de vegetación natural (pasto y gramíneas), el 35\% de tierra arcillosa y el 15\% de raíces. Los componentes culturales que presenta esta capa son fragmentos cerámicos (inclusiones ocasionales). Es de origen natural y cubre por completo a la unidad.

\section{Capa A}

Es de color marrón oscuro, consistencia semicompacta y textura gruesa. Está conformada por piedras trabajadas de diferentes dimensiones y tierra arcillosa. Los componentes culturales que presenta esta capa son algunos restos óseos. Esta capa fue identificada en las subunidades I y II, corresponde al derrumbe de las estructuras.

Contexto funerario 1: Fue registrado dentro de la cámara funeraria 1.

- Estructura funeraria: Es una cámara de planta irregular, orientada de oeste a este. Se ubica hacia el lado oeste del muro $\mathrm{N}^{\circ} 01$ a una altura aproximada de $1.10 \mathrm{~m}$. con respecto a la base. La cámara mide 
0.50m de largo (W-E), $0.38 \mathrm{~m}$ de ancho (N-S) y $0.25 \mathrm{~m}$ de altura; la cubierta fue elaborada con piedras largas y planas de $0.30 \mathrm{~m}$ de diámetro.

- Individuo: Corresponde a infantes de sexo indeterminado en campo cuya posición se encuentra completamente disturbada. La orientación del contexto es de NE-SW, hacia el lado norte se puede observar algunas vértebras y la mayoría de huesos largos y hacia el lado sur las costillas y huesos cortos, entre otros.

- Asociaciones: Hacia el lado sureste del contexto se identificó un elemento lítico de forma rectangular de color verdeazulado, colocado como ofrenda.

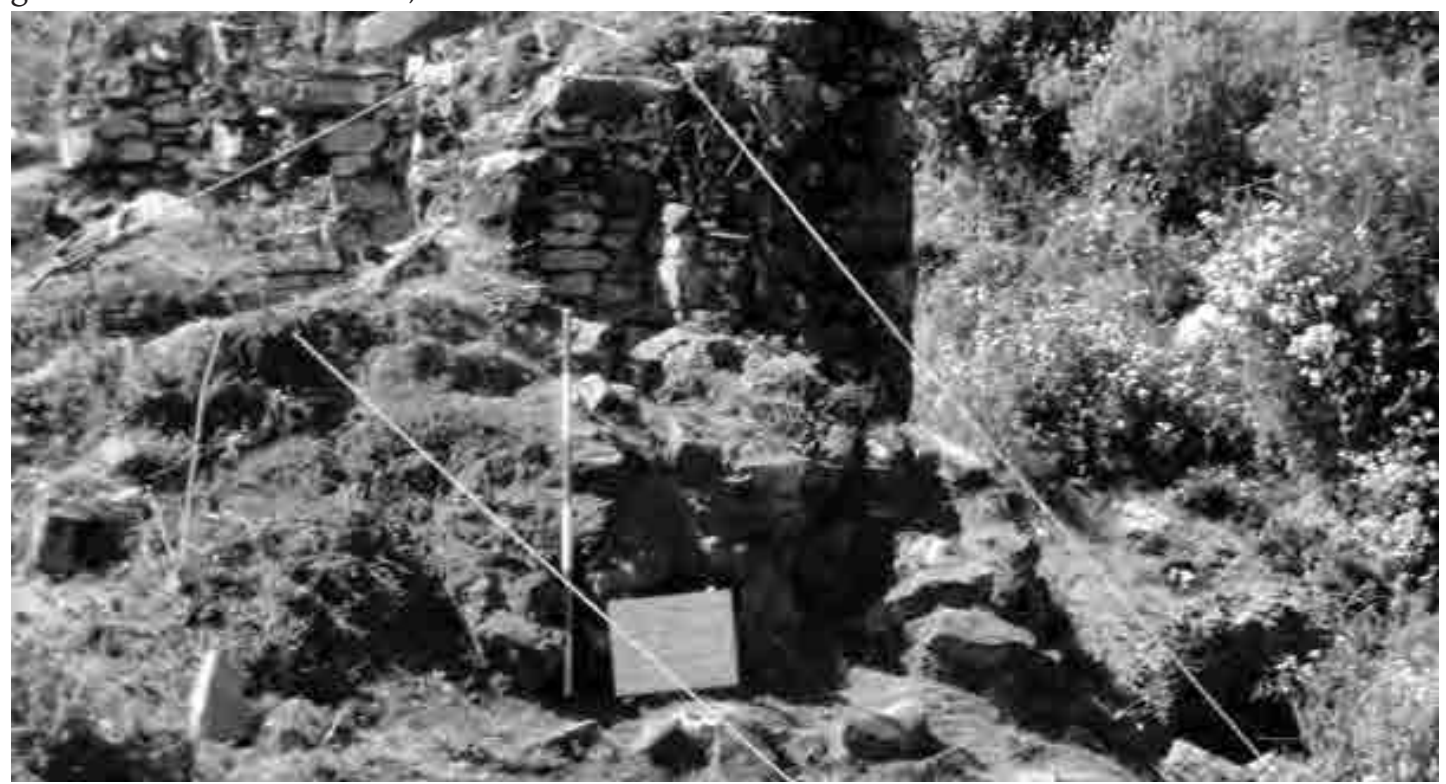

Figura 28: Vista panorámica de la unidad 7 con el hallazgo del Contexto Funerario $N^{\circ} 01$.

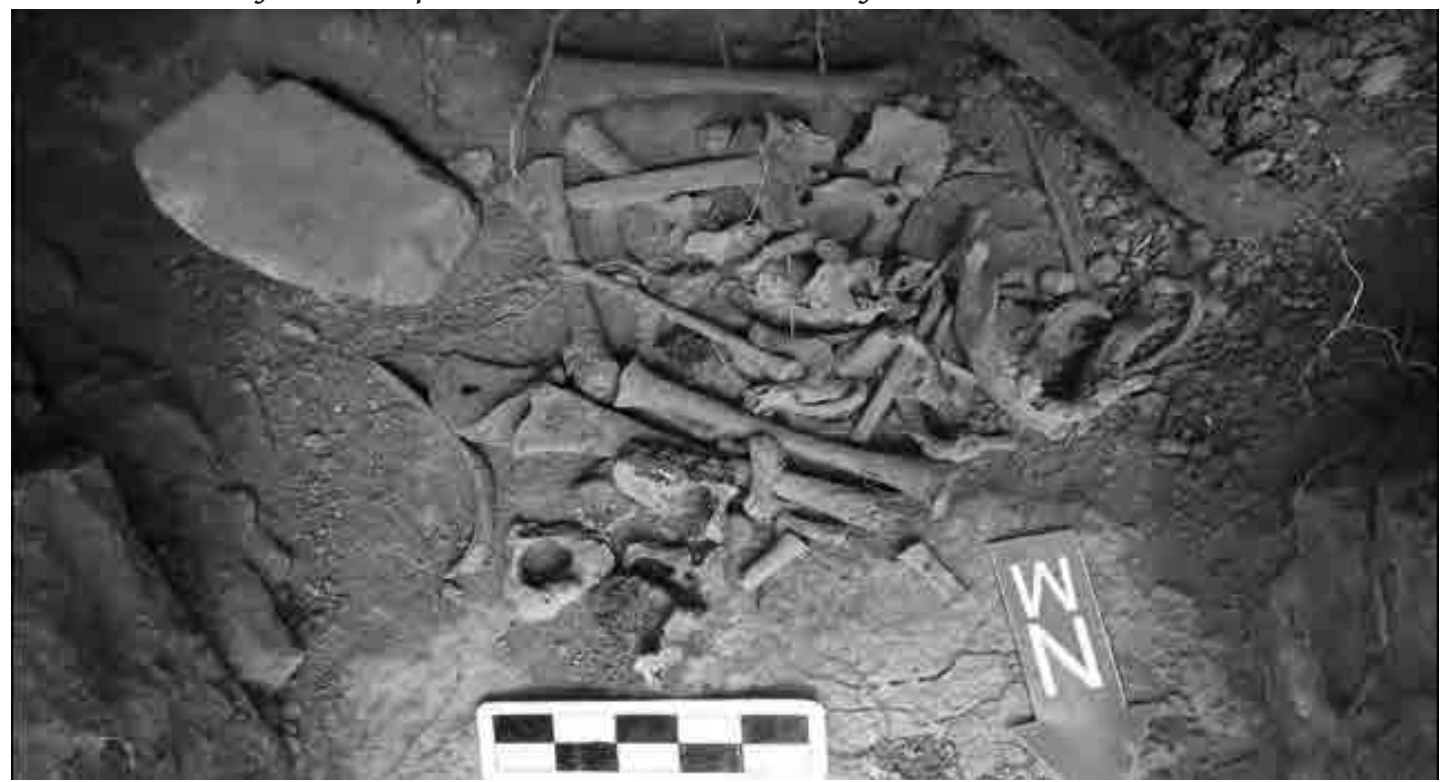

Figura 29: Vista en planta del Contexto Funerario 1, ubicado en la cámara funeraria del muro $N^{\circ} 01$ - subunidad I. 


\section{Capa B}

Esta capa es de color gris, consistencia compacta y textura gruesa. Presenta inclusiones de piedras trabajadas (derrumbe de muros), material cerámico y óseo. Esta capa fue registrada en la subunidad II y corresponde el primer nivel de derrumbe. Tiene un grosor de 0.38 metros.

\section{Capa C}

Esta capa es de color marrón oscuro, consistencia semicompacta y textura fina. Se conforma por tierra arcillosa, piedras trabajas, grava, material óseo y cerámico. Tiene un grosor de 0.22 metros.

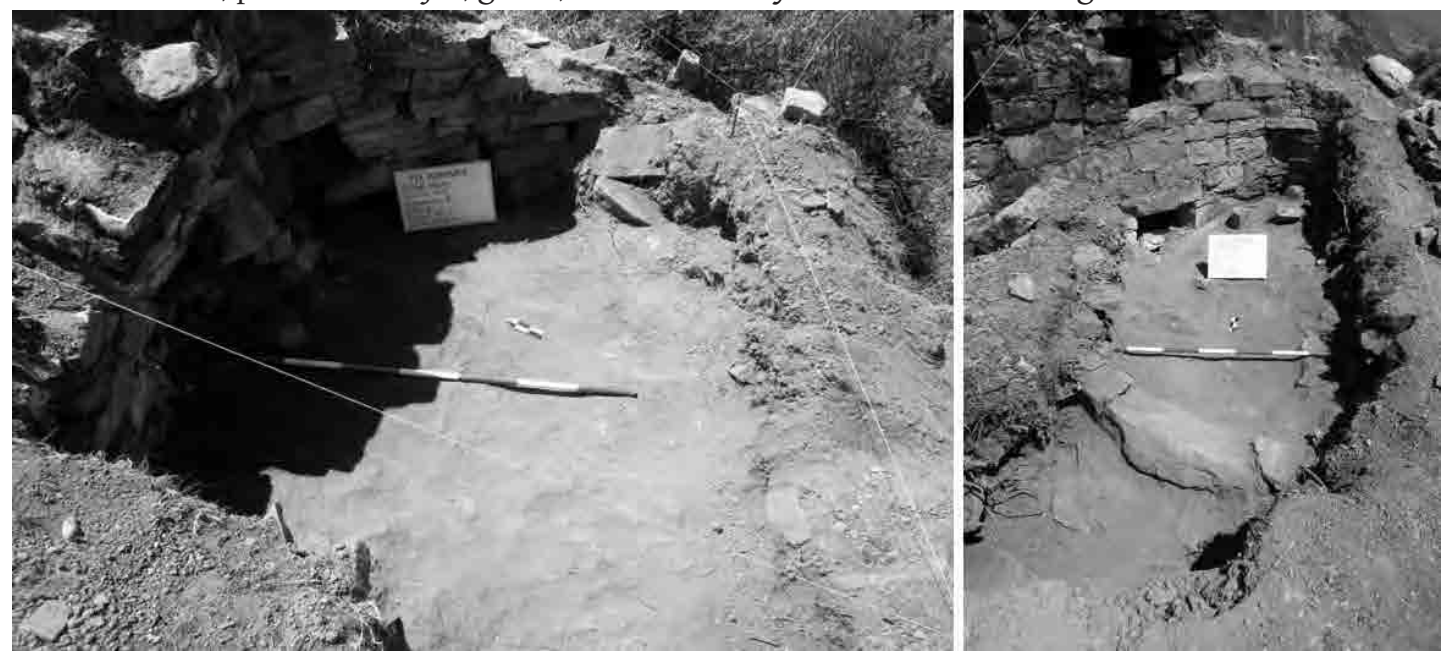

Figura 30 (izquierda): vista panorámica de la capa B, registrada en la subunidad II. Figura 31 (derecha): vista panorámica de la

\section{Apisonado $\mathrm{N}^{\circ} 01$} capa C, ubicada en la subunidad II.

Se ubica en la subunidad II. Este apisonado es de color marrón claro, presenta una consistencia semicompacta y una textura fina, de $1 \mathrm{~cm}$ de grosor, elaborado de arcilla fina y grava. No se registró ma-

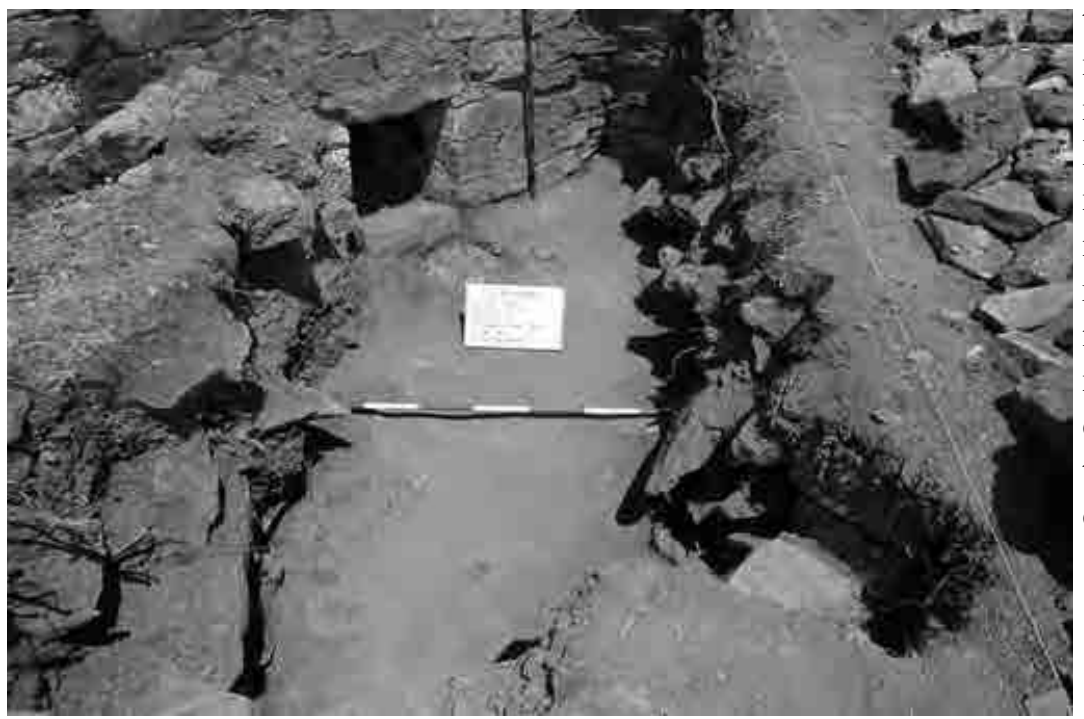
terial cultural. El apisonado fue utilizado para nivelar la superficie de la roca madre, esta capa no fue excavada, solo se realizó un cateo de 0.40 x $0.40 \mathrm{~m}$ de lado ubicado frente al vano de la cámara del muro 2. Sobre este apisonado se identificaron los siguientes contextos y hallazgos:

Figura 32: vista panorámica del apisonado $N^{\circ} 01$, situado en la subunidad II. 
Contexto $\mathrm{N}^{\circ}$ 01: Se ubica a $0.74 \mathrm{~m}$ de distancia hacia el sur del muro $\mathrm{N}^{\circ} 03$, a una profundidad de $1.15 \mathrm{~m}$ del nivel superficial, sobre el apisonado $\mathrm{N}^{\circ} 01$; se conforma por dos objetos líticos (cantos rodados).
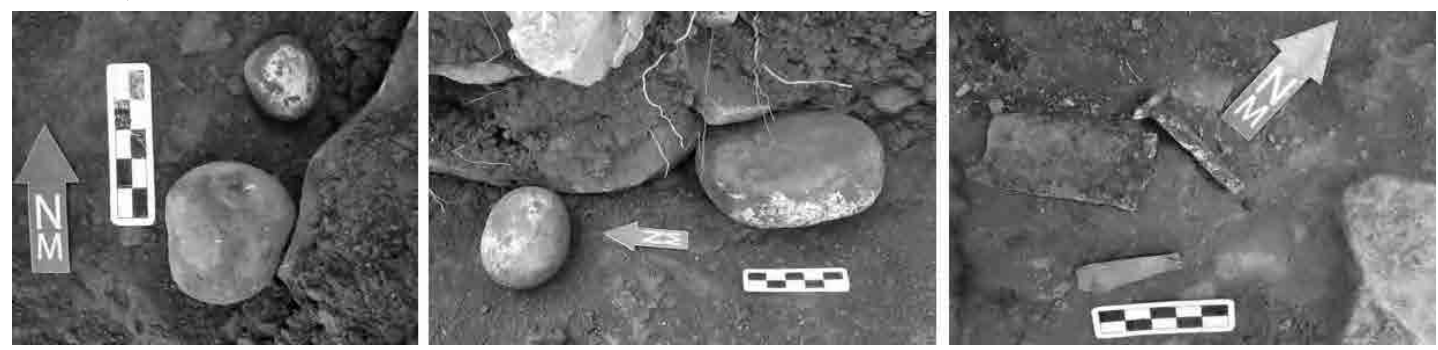

Figura 33 (izquierda): Vista de planta del contexto $N^{\circ} 01$. Figura 34 (centro): vista de perfil del contexto $N^{\circ} 02$, situado en la subunidad I. Figura 35 (derecha): vista de planta del contexto $N^{\circ} 03$, situado en la Subunidad I.

Contexto $\mathrm{N}^{\circ}$ 02: Se ubica a 1.70m de distancia hacia el sur del muro $\mathrm{N}^{\circ} 03$ (límite de la unidad, lado este) y a una profundidad de $1.10 \mathrm{~m}$ del nivel superficial, sobre el apisonado 1. Está constituido por tres elementos: cantos rodados (batanes y proyectiles).

Contexto $\mathrm{N}^{\circ}$ 03: Se ubica a $0.12 \mathrm{~m}$ de distancia del muro 2 (lado oeste) y a $0.53 \mathrm{~m}$ de profundidad del umbral del vano de dicho muro, sobre el Apisonado 1. Se conforma por tres elementos: un clavo, una lámina de metal y un fragmento óseo humano (costilla). Este contexto evidencia el uso de este espacio durante el periodo de Transición Tawantinsuyu - Colonial.

Hallazgo $\mathrm{N}^{\circ}$ 01: Se ubica $0.13 \mathrm{~m}$ de distancia al oeste del muro 1 y a $0.60 \mathrm{~m}$ de distancia al norte del muro 1, sobre el Apisonado 1. Se conforma por un artefacto lítico (un chancador).
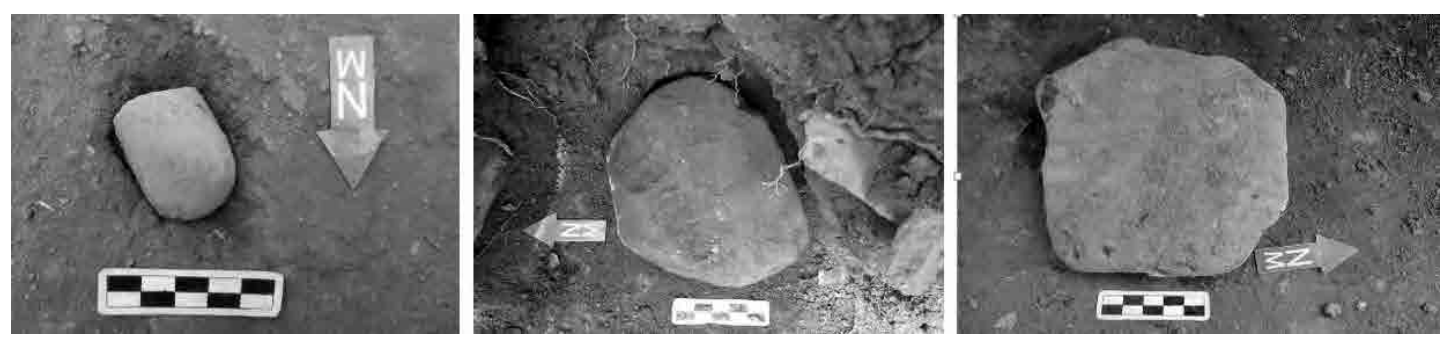

Figura 36 (izquierda): Vista planta del hallazgo $N^{\circ} 01$ correspondiente a un chancador. Figura 37 (centro): vista en detalle del Hallazgo $N^{\circ} 02$ - batán. Figura 38 (derecha): vista de detalle del batán, Hallazgo $N^{\circ} 03$.

Hallazgo 2: Se ubica a 1.85m al sur del muro 2, a una profundidad de 1.00m de la superficie. Está conformado por un artefacto lítico (batán).

Hallazgo 3: Se ubica a 1.00m al lado sur del muro 2, (límite de la unidad en el oeste) y a una profundidad 1.10m de la superficie. Es un artefacto lítico (batán).

\section{Apisonado $\mathrm{n}^{\circ} 02$}

El apisonado se caracteriza por ser de color gris, presenta consistencia semicompacta y textura fina. Fue registrado en la subunidad II, utilizado para nivelar la superficie irregular de la roca madre. 


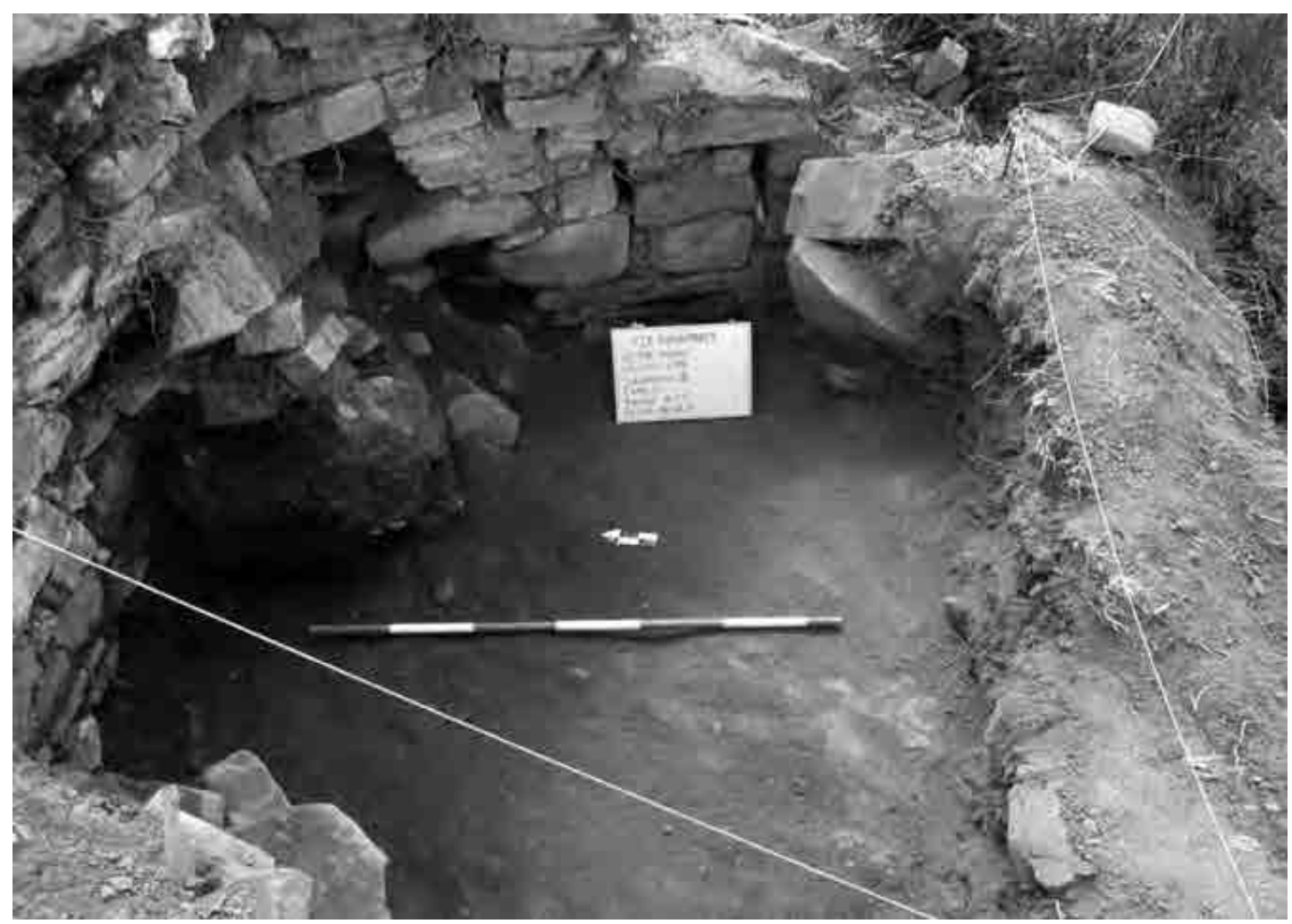

Figura 39: vista en planta del apisonado $n^{\circ} 02$ registrado en la subunidad II.

\section{4.- UNIDAD 9:}

La unidad $\mathrm{N}^{\circ} 09$, de $6 \times 6 \mathrm{~m}$, se encuentra en el sector medio del sitio, emplazada sobre un terreno irregular, hacia el lado sureste de la Unidad 7 y hacia el noreste de la Unidad 11. Se emplazó en la parte interna y externa de un edificio Kullpi. La funcionalidad de esta unidad está relacionada a una actividad doméstica, teniendo en cuenta la gran cantidad de objetos líticos utilizados para la molienda (batanes, chancadores, etc.) de diversos alimentos. Se trata de un recinto de planta ovalada, con muros muy deteriorados. Fue divida en tres subunidades según la disposición de los elementos constructivos: I ubicada al norte y la II ubicada al sur. La secuencia estratigráfica identificada fue:

\section{Capa Superficial}

Está cubierta de vegetación herbácea y arbustiva, así como tierra y piedras, tiene $0.07 \mathrm{~m}$ de grosor.

\section{Capa A}

Es de tierra arcillosa color beige, consistencia semicompacta y textura gruesa. Presenta piedras trabajadas producto del colapso de muros, mezclados con la tierra y material cerámico, óseo humano y óseo animal (asta de cérvido). En la Subunidad I se registraron el Hallazgo 1 al 4; en la Subunidad II los Hallazgos 5 al 7. Esta capa corresponde al derrumbe de las estructuras que conforman los Recintos 1 y 2 . Tiene un grosor de 0.60 metros en promedio.

Hallazgo 1: Elemento fósil no identificado, posiblemente, un bivalvo. 
Hallazgo 2: Elemento fósil no identificado.

Hallazgo 3: Piruro de arcilla con agujero circular.

Hallazgo 4: Objeto laminado de forma circular, orejera o colgante.

Hallazgo 5: Asta de venado fragmentado, de color marrón claro de $7 \mathrm{~cm}$ de largo.

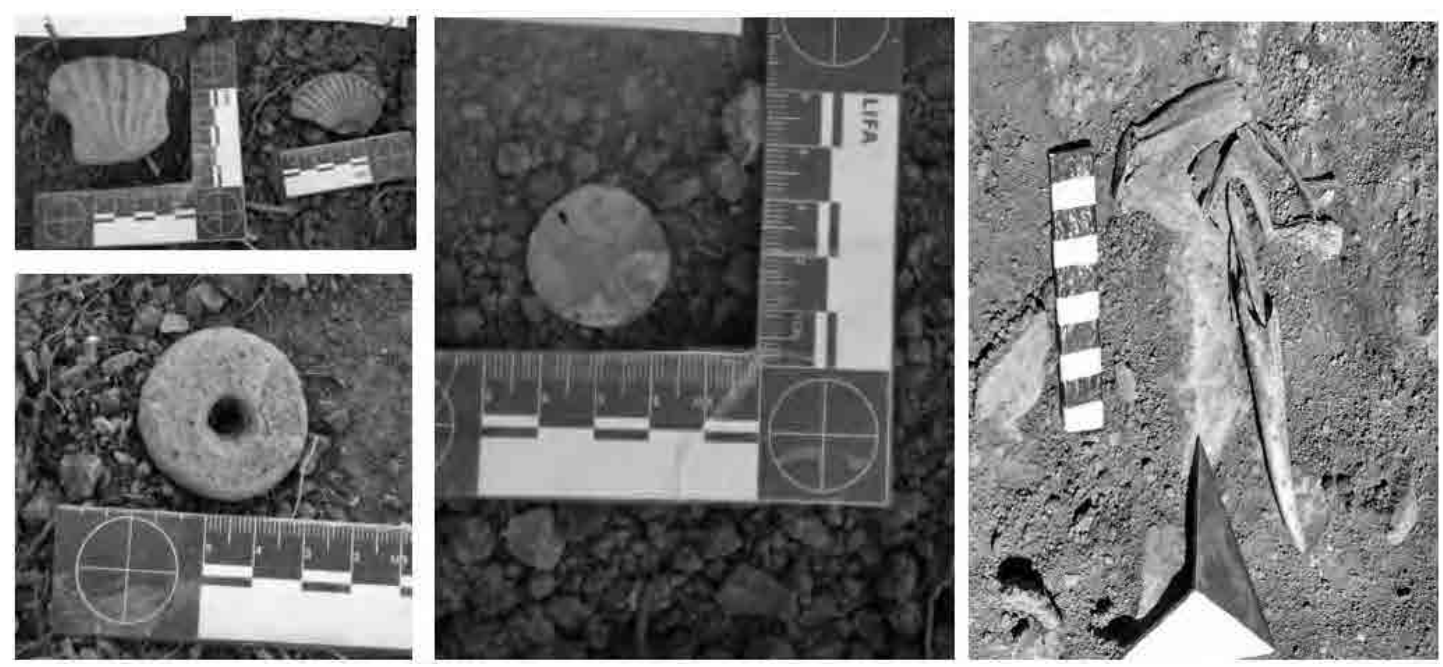

Figura 40 (superior izquierda): Vista de los hallazgos 1 y 2. Figura 41 (inferior izquierda): piruro de cerámica. Figura 42 (centro) hallazgo 4, Capa A, orejera o colgante de metal. Figura 43 (derecha): Vista de detalle del Hallazgo 5 - Subunidad II.

Hallazgo 6: artefacto lítico (chancador).

Hallazgo 7: instrumento musical de viento óseo alargado y es de color crema. En un extremo presenta una boquilla (ingresa el aire) y en el otro un pequeño agujero por donde sale el aire. Su acabado es alisado y mide $11.5 \mathrm{~cm}$ de largo, $2.2 \mathrm{~cm}$ de ancho y $1.5 \mathrm{~cm}$ de grosor. Su estado de conservación es bueno.

\section{Capa B}

Se halló al interior de la estructura del contexto funerario 1.

Contexto Funerario 1: Se ubica al noroeste del recinto 2 (Subunidad II), se encuentra disturbado al 50\% y está conformado por varios individuos de diversos sexos y edades. Sus componentes son:

- Estructura funeraria: La estructura es subterránea, presenta planta ovalada, la cual posee de suroeste a noreste: $1.50 \mathrm{~m}$ de largo, $0.80 \mathrm{~m}$ de ancho y $0.80 \mathrm{~m}$ de altura. Para su elaboración se cortó la roca madre y hacia el lado suroeste se observa un pequeño paramento elaborado con piedras canteadas de $0.08 \mathrm{~m}$ a $0.15 \mathrm{~m}$ de largo, los cuales fueron unidos con mortero de arcilla de color gris. Dentro de la cámara funeraria se registró la Capa B de color marrón, de consistencia suelta y de textura fina; conformada por el 55\% de tierra arcillosa, el 2'\% de grava fina y el 15\% de raíces. Debajo del nivel de la estructura y adecuando el relieve de la roca madre se siguió recuperando restos óseos, en un área a modo de osario.

- Individuo: El Contexto Funerario 1 se constituye por el entierro de varios individuos, observándose una mayor presencia de restos óseos aglutinados hacia el lado suroeste de la estructura, princi- 
palmente de cráneos y de huesos largos. Estos cráneos presentan evidencia de deformación craneana. A pesar de que el contexto estaba medianamente disturbado, se logró identificar un cuerpo ubicado en la parte media de la estructura, el cual presenta deposición original, posición flexionada orientada de norte a sur cuyo cráneo está de costado orientándose de este a oeste. Asimismo, se recuperó restos óseos de camélidos los cuales estaban mezclados con el material óseo humano.

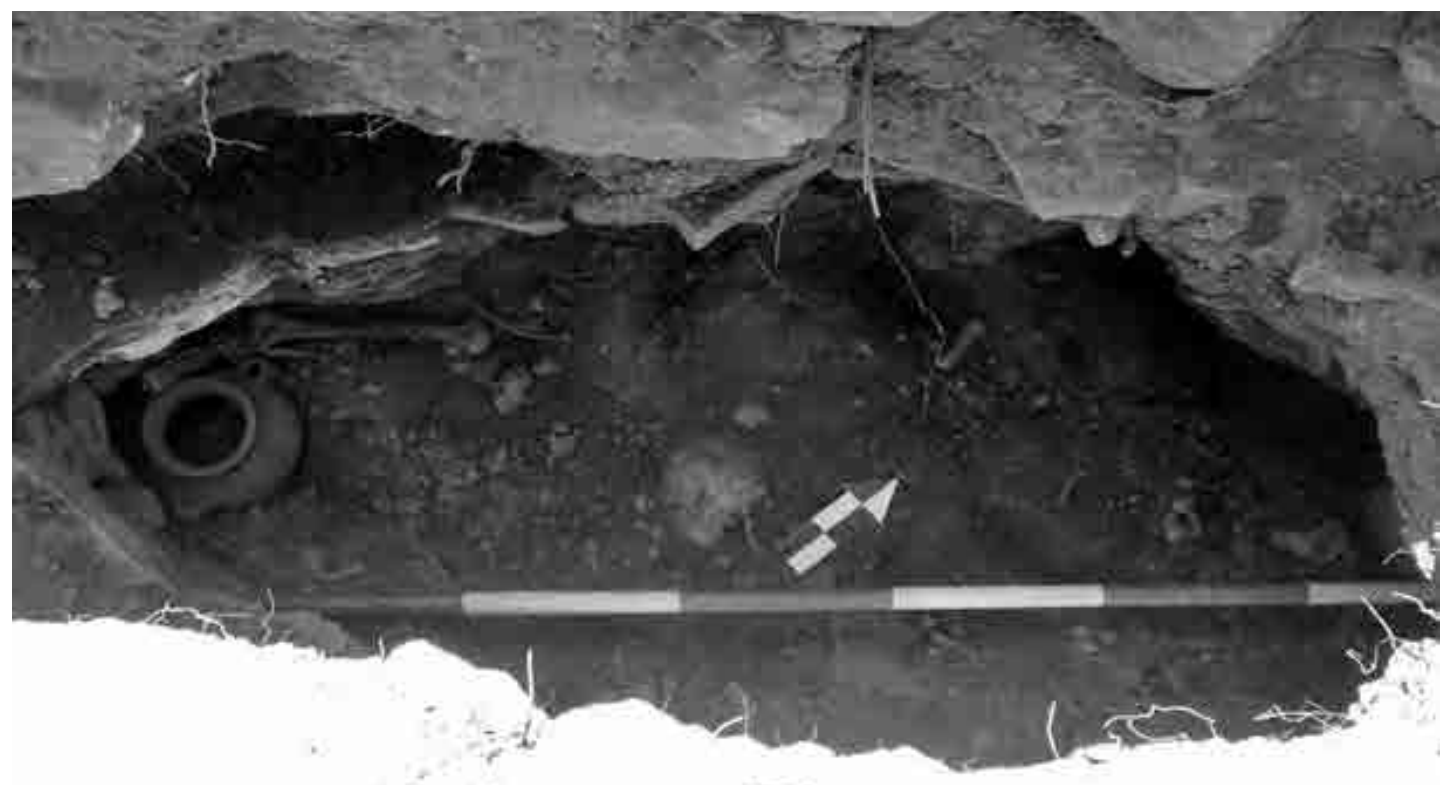

Figura 45: vista de detalle de un individuo en posición flexionada. C.F.1.

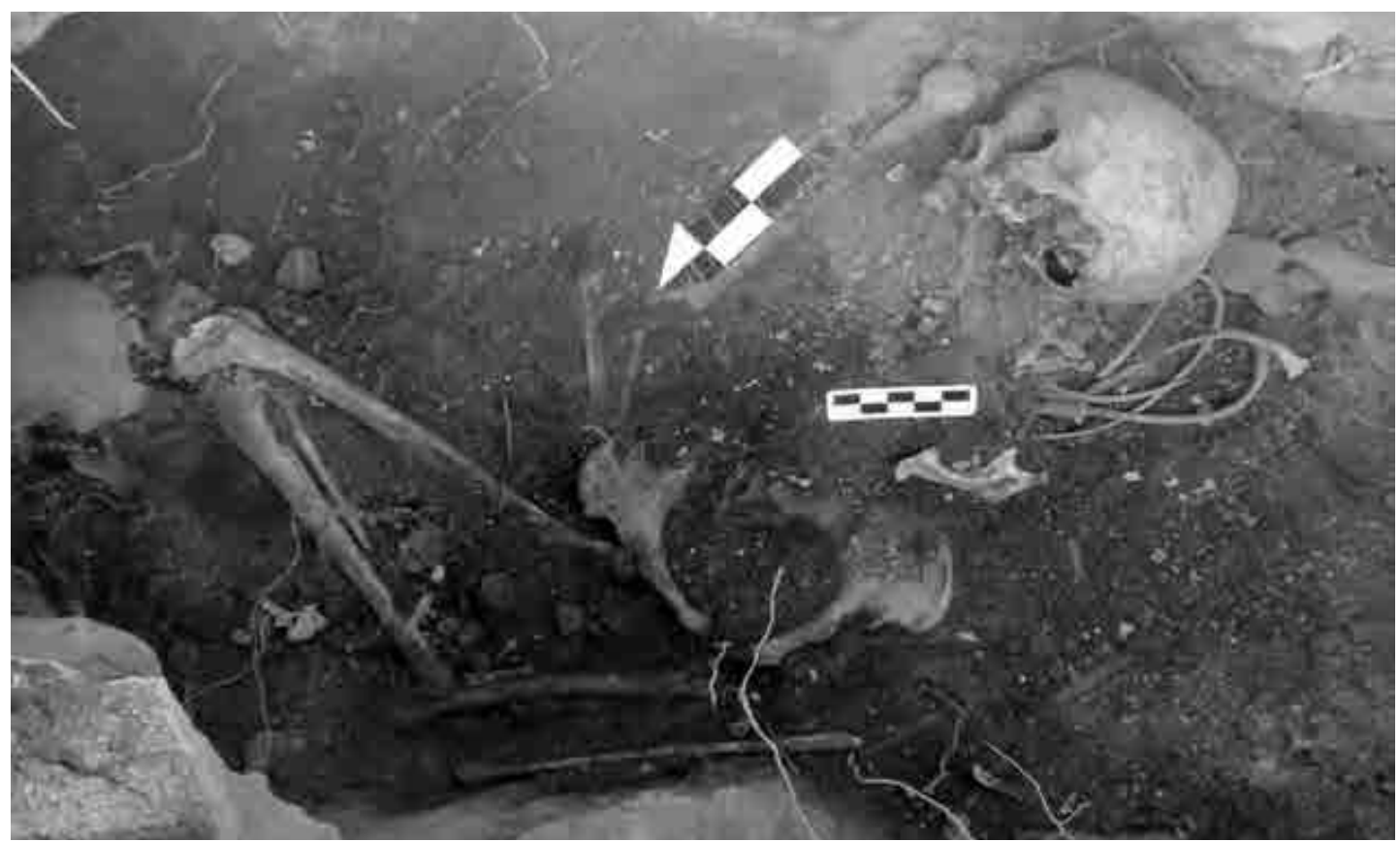

Figura 44: Vista panorámica de la cámara subterránea que contiene al contexto funerario $N^{\circ} 01$. 


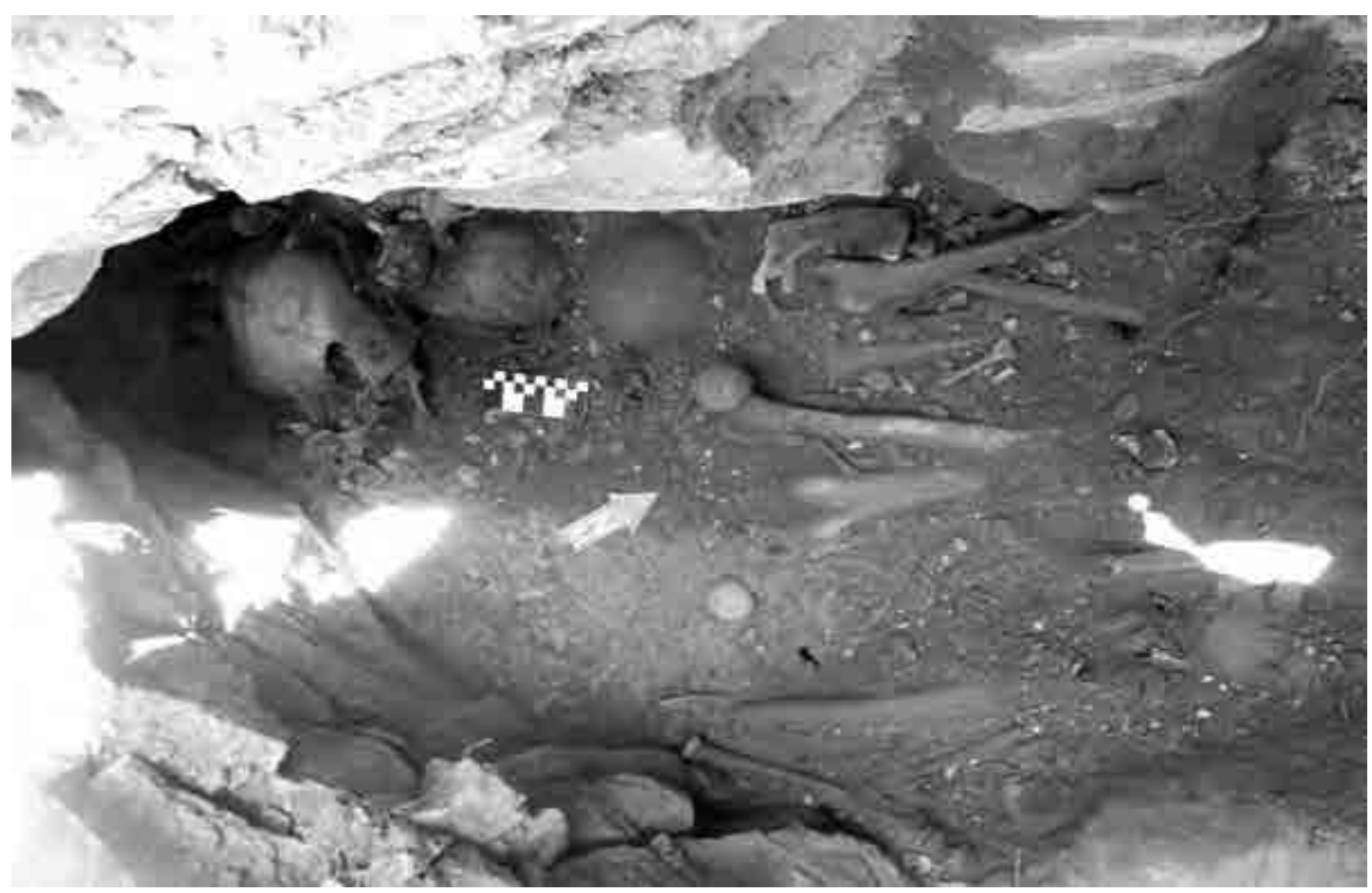

Figura 46: Vista panorámica del contexto funerario $N^{\circ} 01$.

- Asociaciones: Dentro de las asociaciones se recuperó hacia el noreste un objeto lítico de forma rectangular de color azul verdoso; hacia el extremo suroeste se registró una olla de forma globular, asas cintadas y base cóncava. Asimismo, en la parte media de la estructura se recuperó una aguja elaborada en óseo animal, la cual presenta en uno de sus extremos un agujero central, de acabado pulido.

\section{Capa C}

Capa de tierra arcillosa de color beige, de consistencia semicompacta y textura gruesa; presenta inclusiones de piedras caídas del muro 6 (derrumbe). No se recuperó material cultural dentro de esta capa. Fue identificada en la Subunidad III.

Figura 47: Vista de detalle de la Capa B, ubicada en la Subunidad III.

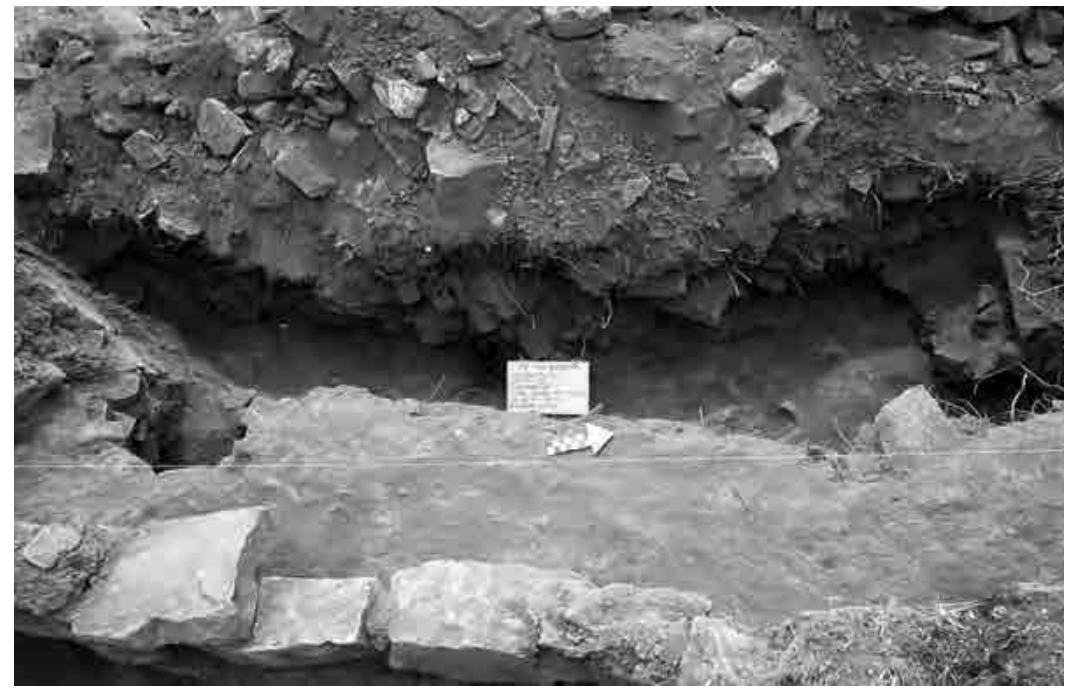




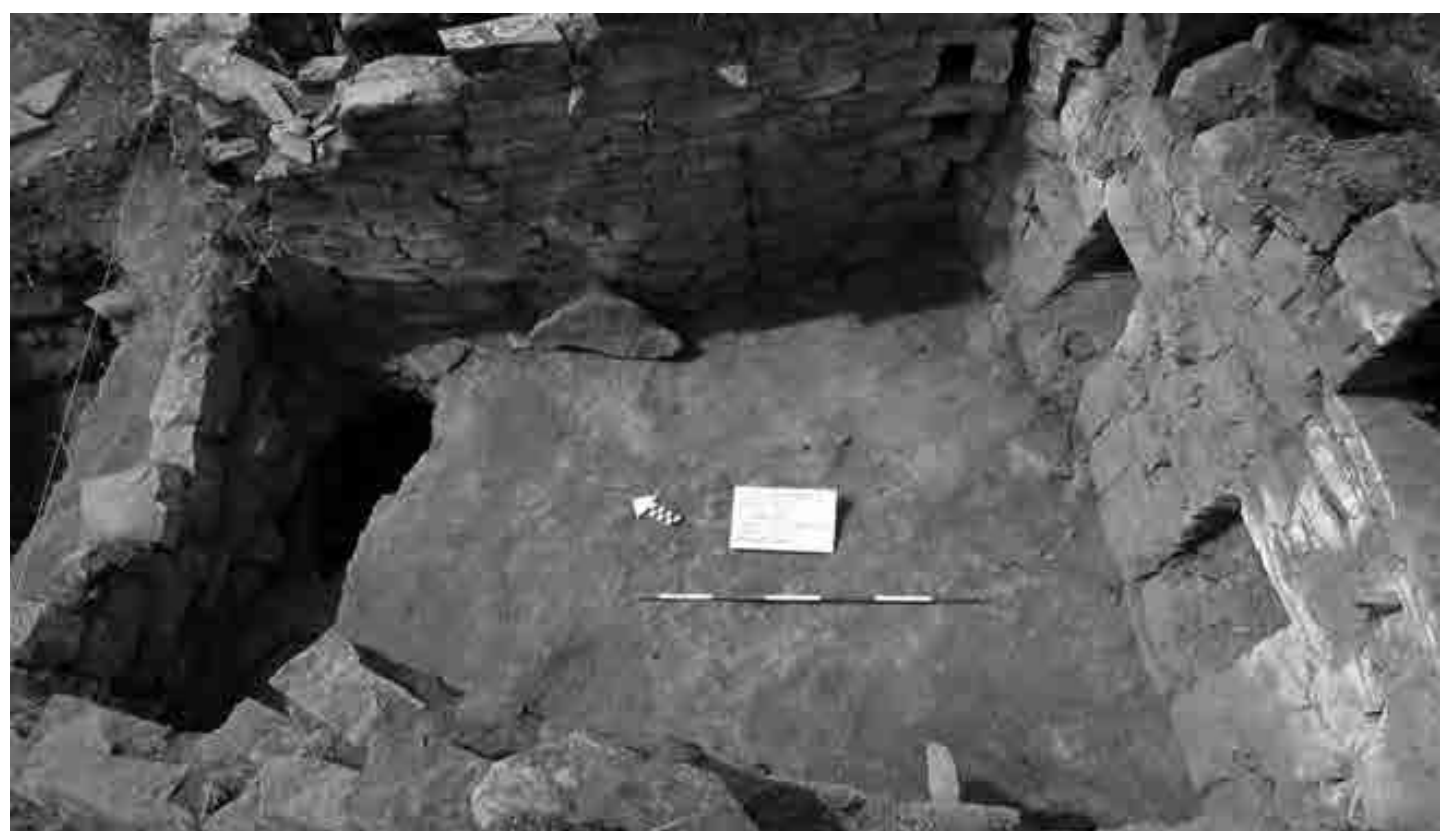

Figura 48: Vista panorámica del Apisonado $N^{\circ} 02$ (recinto 2) con la estructura funeraria al lado izquierdo.

\section{Apisonado 2}

Se identificó dentro del recinto 2 (subunidad II). Es de tierra arcillosa mezclada con grava, de color beige, de consistencia semicompacta y de textura fina, de $0.01 \mathrm{~m}$ de grosor. Fue elaborado para nivelar la superficie irregular de la roca madre.

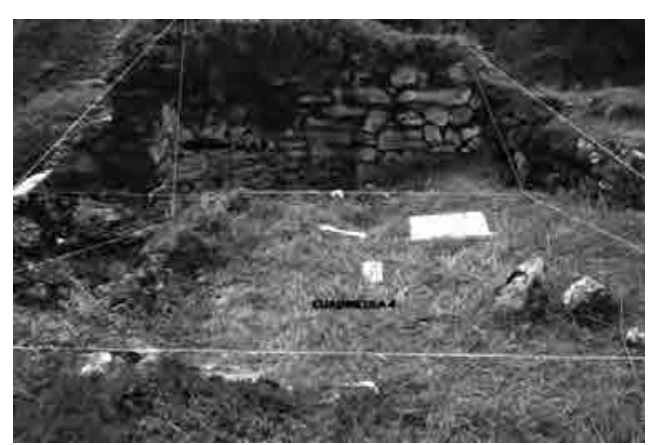

\section{Apisonado 3}

Ubicado en la Subunidad III, de tierra arcillosa mezclada con grava, color beige, de consistencia semicompacta y textura fina, elaborado para nivelar la superficie irregular de la roca madre.

\section{5.- UNIDAD 11:}

Se encuentra en el sector medio del sitio, tiene un área de $4 \mathrm{x} 4$ metros, situada en el interior y exterior de un edificio arquitectónico tipo Kullpi. Fue dividida en 3 subunidades:

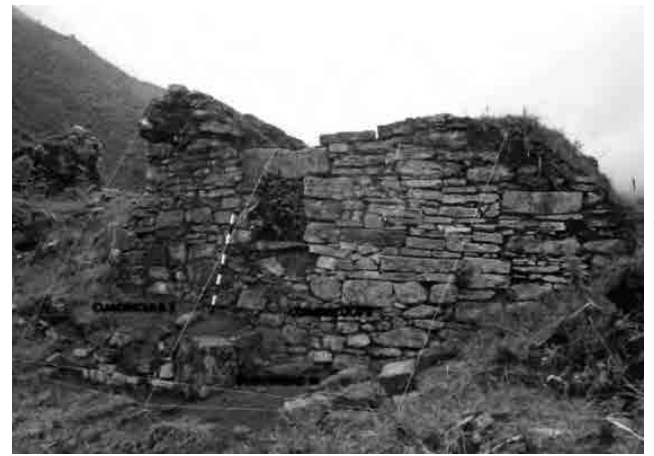

Subunidad I: Comprende el área interior del Kullpi.

Subunidad II: Comprende el área exterior del Kullpi, cerca al muro 1 (muro noroeste) del recinto.

Subunidad III: Comprende la estructura arquitectónica tipo Cista.

Figura 49 (superior): Vista de las cuadriculas que conforman la subunidad I. Figura 50 (inferior): Vista de las cuadriculas que conforman la subunidad II. Se observa también, la subunidad III. Unidad 9. 
El Kullpi presenta planta en forma de "D", la técnica constructiva es mampostería con doble hilera arbitraria con incrustaciones de pachilla y el estado de conservación es regular; el techo está completamente derrumbado, aún se conservan los lados de los muros, el vano es rectangular de $0.80 \mathrm{~m}$. de alto por $0.60 \mathrm{~m}$. de ancho. El espacio interno es de $3.60 \mathrm{~m}$ de largo, $2.90 \mathrm{~m}$ de ancho y una altura interna de $1.90 \mathrm{~m}$. Presenta un muro curvo -el noroeste- y dos muros rectos, el cuarto muro exterior también fue recto, el muro sureste está justo encima del precipicio, mientras que el muro noroeste (opuesto al anterior), tiene un espacio alargado que habría servido para la circulación y tiene una banqueta de refuerzo con un vano o ventana que está encima de la banqueta. Todo el recinto fue levantado sobre la roca madre, incluido la banqueta y la cista. La secuencia estratigráfica identificada es la siguiente:

\section{Capa superficial}

La superficie estaba compuesta por pasto y tierra húmeda y compacta de color marrón, presentando una textura fina. El grosor de esta capa es entre 0.05 a 0.30 metros. Presenta inclusiones de piedras trabajadas procedentes del derrumbe de muros, en la subunidad II se halló fragmentos cerámicos.

\section{Subunidad I}

\section{Capa A}

Al interior del Kullpi, está compuesta por tierra arcillosa semicompacta de color marrón oscuro, textura gruesa (granos de tierra), de un grosor entre 0.05 a 0.10m. Presenta inclusión de piedras medianas procedentes de los muros y lajas del techo, un fragmento óseo y una punta lítica hoja de laurel.

\section{Capa B}

Está compuesta por tierra compacta de color marrón oscuro mezclada con piedras, textura gruesa, de entre 0.10 y $0.27 \mathrm{~m}$ de grosor. Presenta mayor presencia de piedras del techo derrumbado, con escasos fragmentos cerámicos y óseos.

\section{Capa C}

Está compuesta por tierra semicompacta de color marrón oscuro, textura gruesa, de entre 0.20 y $0.60 \mathrm{~m}$ de grosor. Se halló al interior de esta capa piedras medianas colapsadas de los muros y techo, así como fragmentos cerámicos.

\section{Capa D (Apisonado)}

Está compuesta por tierra compacta de color marrón oscuro (casi negro), textura gruesa, elaborada sobre la roca madre. Tiene $0.02 \mathrm{~m}$ de grosor. En este nivel se puede definir los vanos y cámaras ubicadas al interior del recinto.

\section{Subunidad II}

\section{Capa K}

Está compuesta por tierra arcillosa semicompacta en la cuadricula 1 y compacta en la cuadricula 3 , de color negro, textura gruesa y un grosor entre 0.10 y $0.15 \mathrm{~m}$. Se identificó inclusiones de piedras colapsadas del muro 1 y escasos fragmentos cerámicos y óseos.

\section{Capa L}

Está compuesta por tierra arcillosa semicompacta de color marrón oscuro y textura gruesa. El grosor de la capa es entre 0.10 y $0.15 \mathrm{~m}$. En el interior presenta piedras caídas de los muros del Kullpi y algunos fragmentos cerámicos y óseos. En la cuadrícula 1 se llegó a la roca madre, mientras que en la cuadrícula 3 se continuó con la capa M. 


\section{Capa M}

Está compuesta por tierra semicompacta de color negro y textura fina. El grosor de esta capa es entre 0.05 y 0.10m. Se halló fragmentos cerámicos y óseos.

\section{Subunidad III}

Contexto funerario en cista: Limpiada la capa L se identificó una cista en la parte externa del Kullpi, conteniendo en su interior abundante material cerámico, óseo y lítico. Para registrarlo internamente se usó dos niveles arbitrarios debido al hacinamiento y superposición de materiales en el interior. Esta cista se edificó antes del kullpi, a manera de ofrenda pre-constructiva.

- Estructura funeraria: Esta cista tiene forma ovalada, elaborada con piedras canteadas trabajadas y mampuestas con argamasa (arcilla con grava) en hileras arbitrarias. Tiene un área de $1.35 \mathrm{~m}$ de largo por $0.85 \mathrm{~m}$ de ancho, con una altura de $0.60 \mathrm{~m}$. Las esquinas son curvas y no presenta elementos murarios. El basamento está asentado sobre la roca madre. La cista se orienta de suroeste a noreste. Fue edificado antes del recinto y su estado de conservación es bueno.

- Individuo: se halló restos óseos de una alpaca.

- Asociaciones: El primer nivel presentó vasijas fragmentadas en pequeños grupos (bordes, asas, bases, borde con asa). Se encontró 4 artefactos líticos de bordes y esquinas angulosas, un batán y una mano de moler.

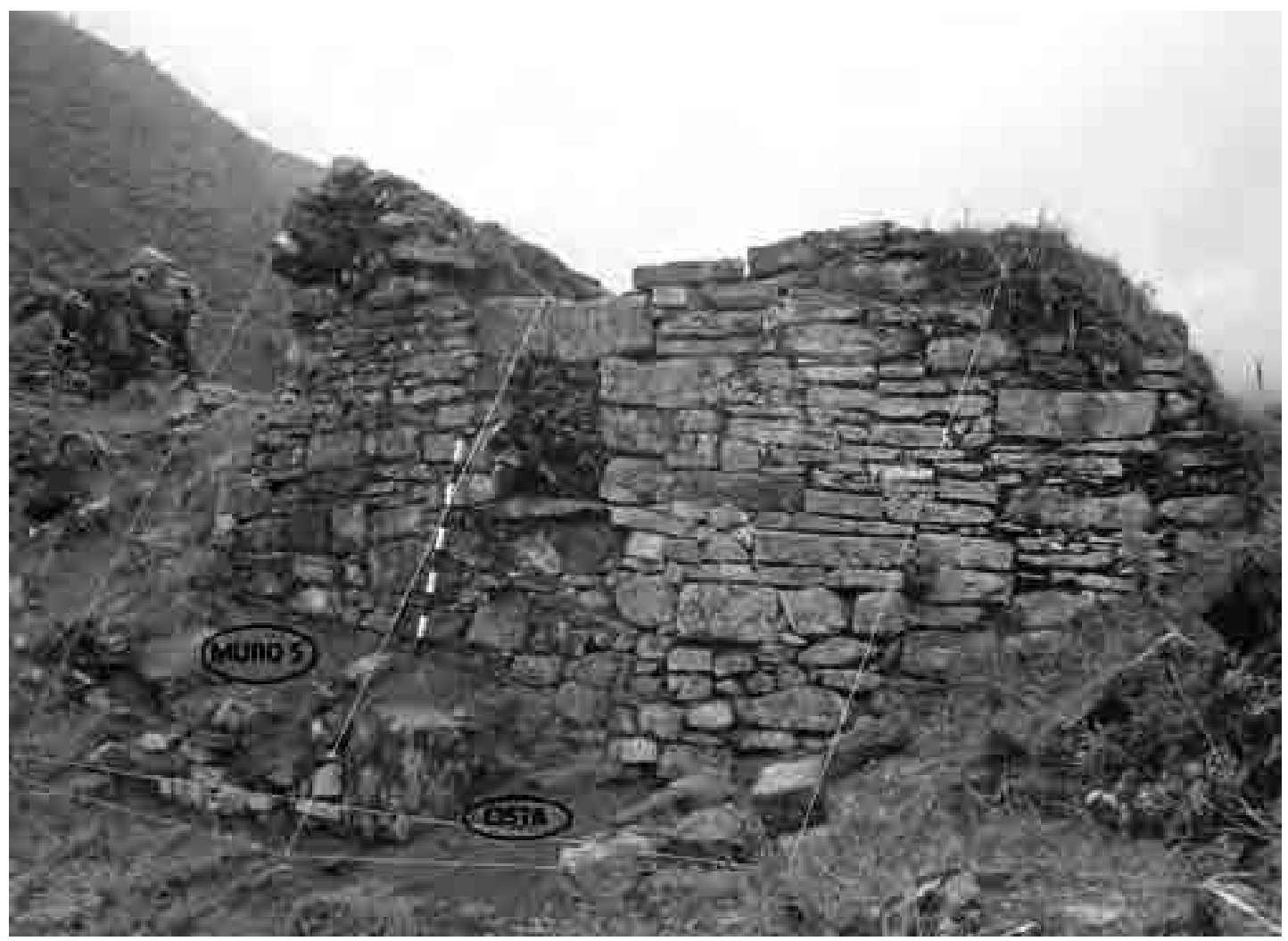

Figura 51: Vista del muro $N^{\circ} 5$ y la cista. 


\section{6.- UNIDAD 14:}

La unidad $\mathrm{N}^{\circ} 14$, de $4 \times 4$ metros, se encuentra situada en el sector bajo del sitio, emplazada sobre un terreno irregular, hacia el sureste de la unidad 13 y al este de la unidad 15. La secuencia estratigráfica identificada es la siguiente.

\section{Capa Superficial}

Esta capa presenta color amarillo (por la vegetación seca). Posee consistencia semicompacta y textura gruesa. Tiene un grosor de $0.05 \mathrm{~m}$. En esta capa se recuperó algunos fragmentos de material cerámico y material óseo. A este nivel de excavación se pudo identificar un muro hacia el lado norte de la unidad.

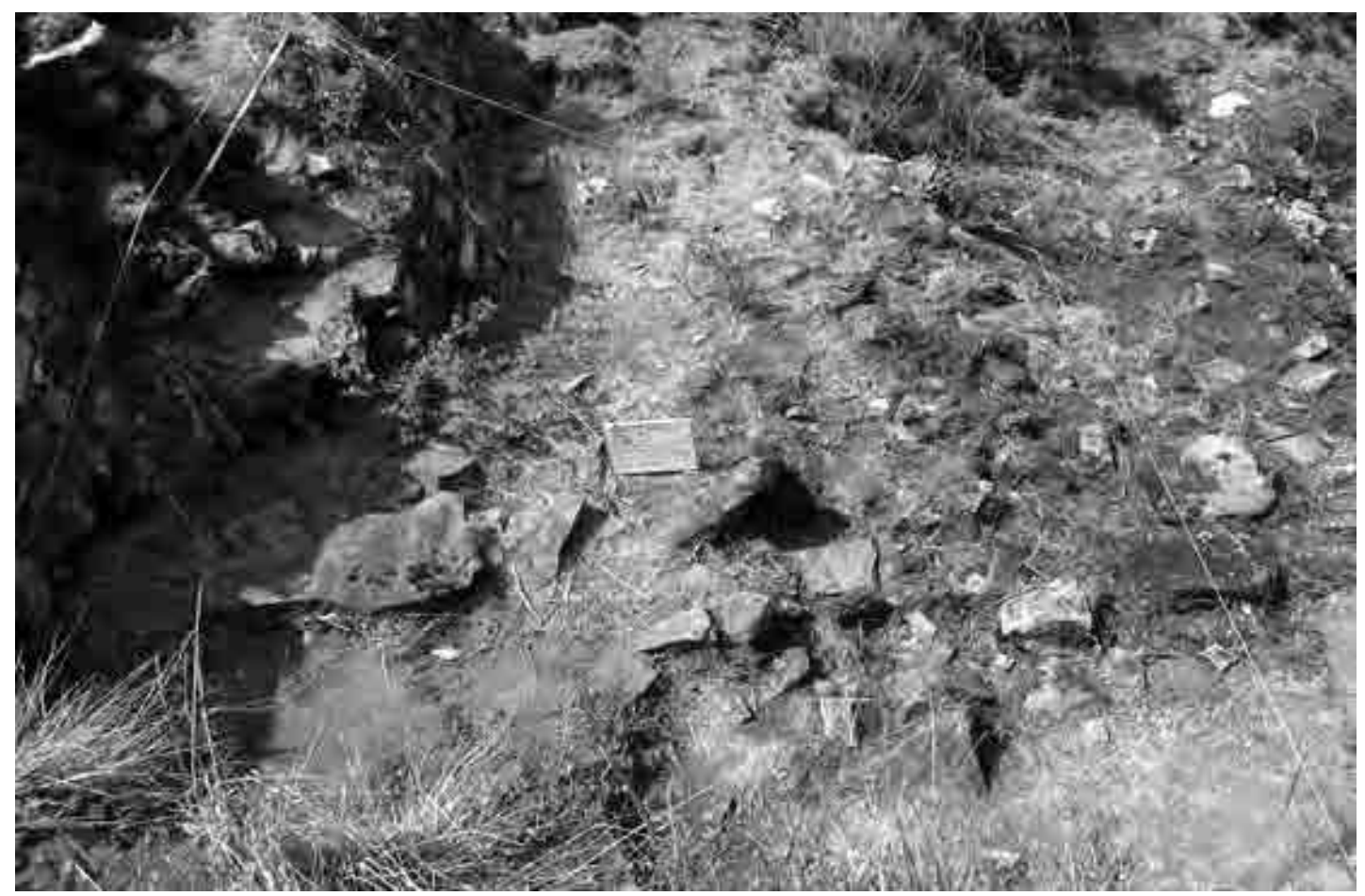

Figura 52: Vista panorámica de la capa superficial de la Unidad $N^{\circ} 14$, obsérvese hacia el lado norte la presencia de un muro.

\section{Capa A}

Esta capa de tierra presenta color beige, de consistencia semicompacta y de textura gruesa. Está conformada por inclusiones de piedras trabajadas (caídas de los muros). Asimismo, se observa inclusiones de fragmentos cerámicos y material óseo. La capa A corresponde a un relleno producto del derrumbe de los muros. Al nivel de esta capa se registraron las cámaras de los contextos funerarios 1 , 2 y 3 ; así como los Hallazgos 1 y 2.

- Contexto Funerario $N^{\circ}$ 01: Fue identificado dentro de una cámara funeraria ubicada hacia el lado noroeste de la unidad.

- Estructura funeraria: se trata de una cámara, para su elaboración se aprovechó parte del paramento del muro $\mathrm{N}^{\circ} 01$ conformando el lado suroeste de la cámara y se cortó la roca madre conformando los lados noroeste y noreste de la estructura. Esta estructura está construida en su totalidad 
con piedras planas de $0.15 \mathrm{~m}$ a $0.20 \mathrm{~m}$ de largo, hacia el lado sureste se observó un alineamiento de piedras unidas con argamasa de arcilla de color gris. La cámara funeraria presenta una orientación de noroeste a sureste, su forma es irregular y sus medidas son: $0.60 \mathrm{~m}$ de ancho, $0.70 \mathrm{~m}$ de altura y $0.50 \mathrm{~m}$ de profundidad. Su estado de conservación es malo ya que no se observa los paramentos del lado noroeste y noreste.

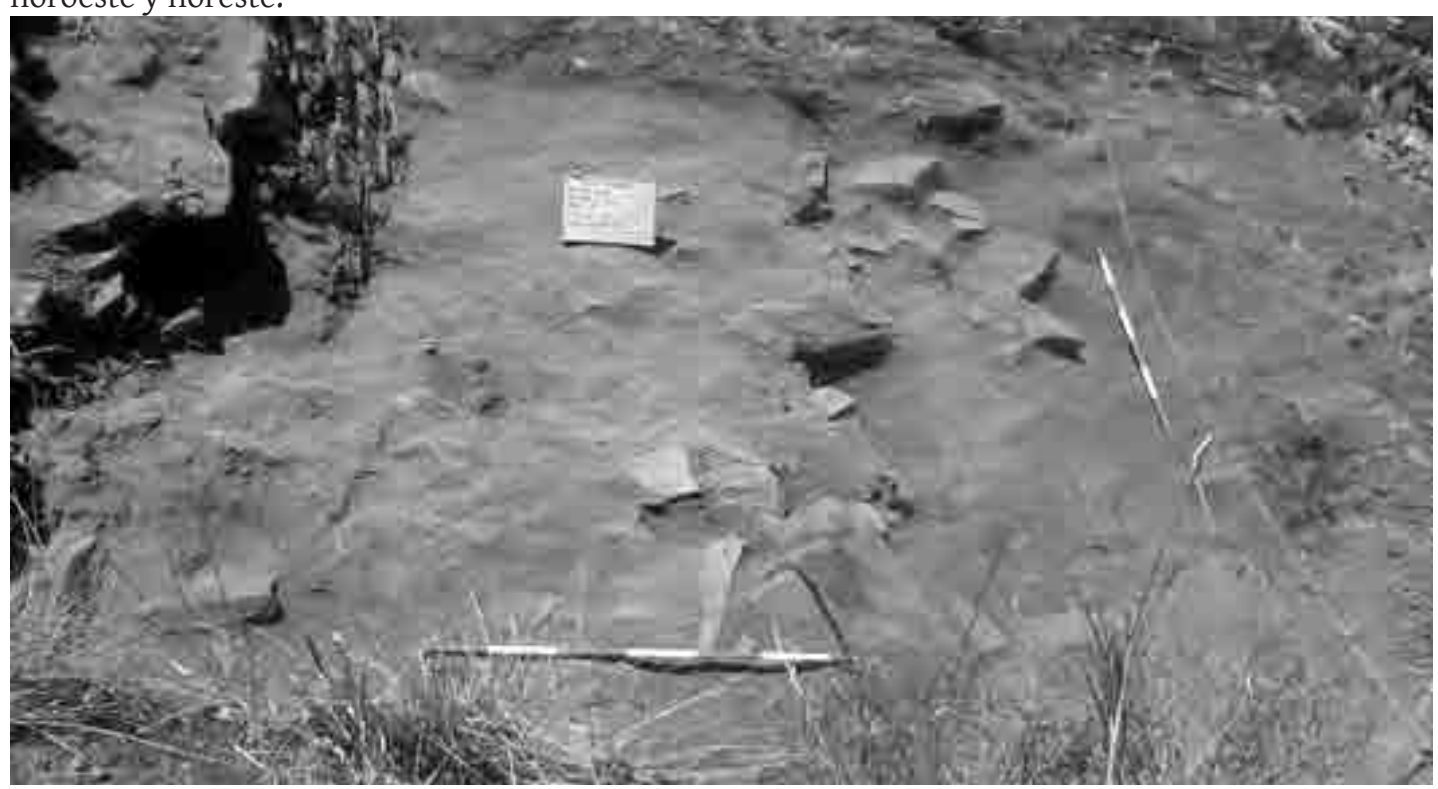

Figura 53: Vista panorámica de la capa A de la Unidad $n^{\circ} 14$.

- Individuo: El contexto funerario 1 está conformado por el entierro de diversos individuos de diferentes sexos y edades (infantes y adultos), los cuales han sido alterados (huaqueo) por ello no se ha logrado identificar ninguna orientación ni posición. Los huesos largos, cortos y planos se encuentran mezclados entre sí dentro de la capa A.
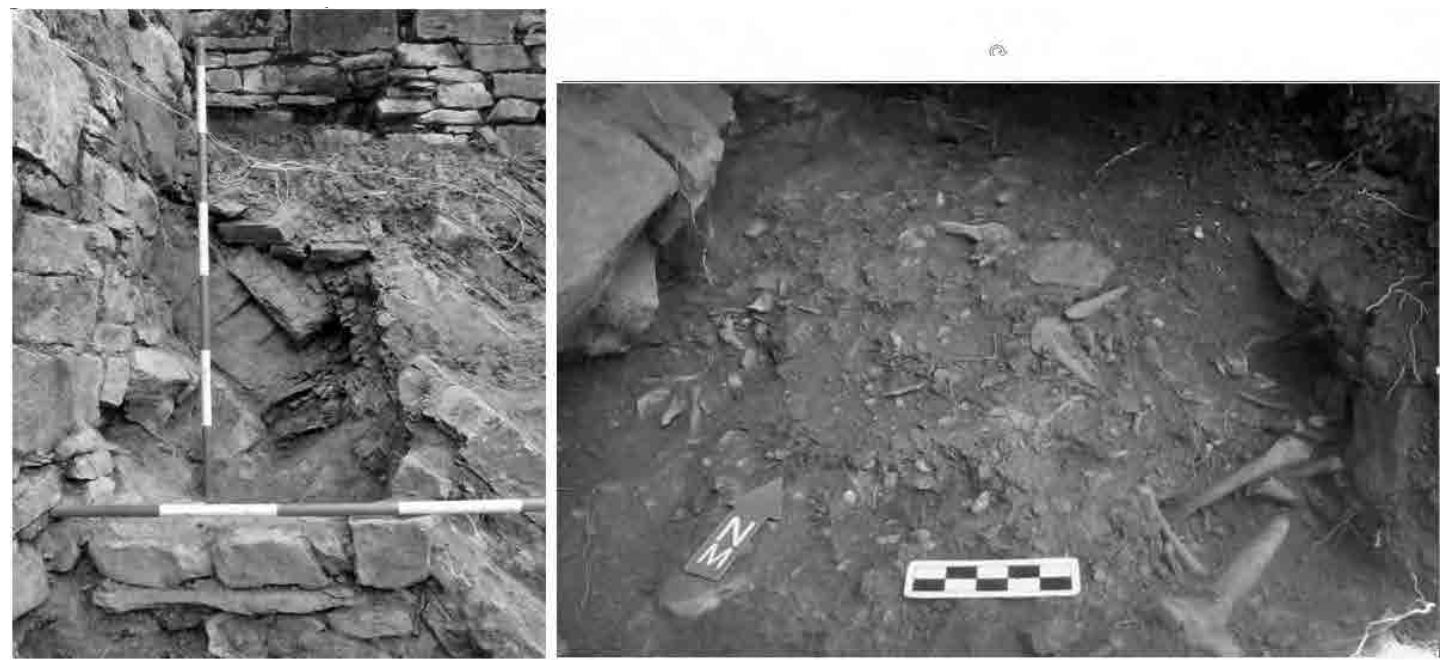

Figura 54 (izquierda): Vista de detalle de la Cámara Funeraria $N^{\circ} 01$. Figura 55 (derecha): Vista de detalle del Contexto Funerario $\mathrm{N}^{\circ} 01$. 
Contexto Funerario 2: Fue recuperado dentro de la cámara funeraria 2, la cual se encuentra ubicada en la esquina suroeste del muro 2.

- Estructura funeraria: Está conformada por una cámara funeraria (2). Esta estructura posee una orientación de suroeste a noreste y su forma es rectangular; fue elaborada en el interior del muro 2 , para ello se utilizó piedras trabajadas de $0.08 \mathrm{~m}$ a $0.15 \mathrm{~m}$ de largo y su cubierta fue elaborada con lajas de $0.50 \mathrm{~m}$ a $0.60 \mathrm{~m}$ de largo. Debido a su regular estado de conservación no se logró determinar la forma de su vano; sin embargo, esta presenta una orientación noroeste a sureste. La cámara mide $0.50 \mathrm{~m}$ de largo, $0.60 \mathrm{~m}$ de ancho y $0.70 \mathrm{~m}$ de profundidad.

- Individuo: El contexto funerario 1 se constituye por un conglomerado de restos óseos, los cuales presentan una orientación de norte a sur y abarca un área de $0.30 \mathrm{~m}$ de largo, $0.23 \mathrm{~m}$ de ancho y $0.10 \mathrm{~m}$ de profundidad. El contexto se encuentra disturbado: hacia el lado norte se puede observar huesos planos y vertebras, y hacia el lado sur se encuentran las costillas y huesos largos.

- Asociaciones: Este contexto no presenta ningún elemento asociado.
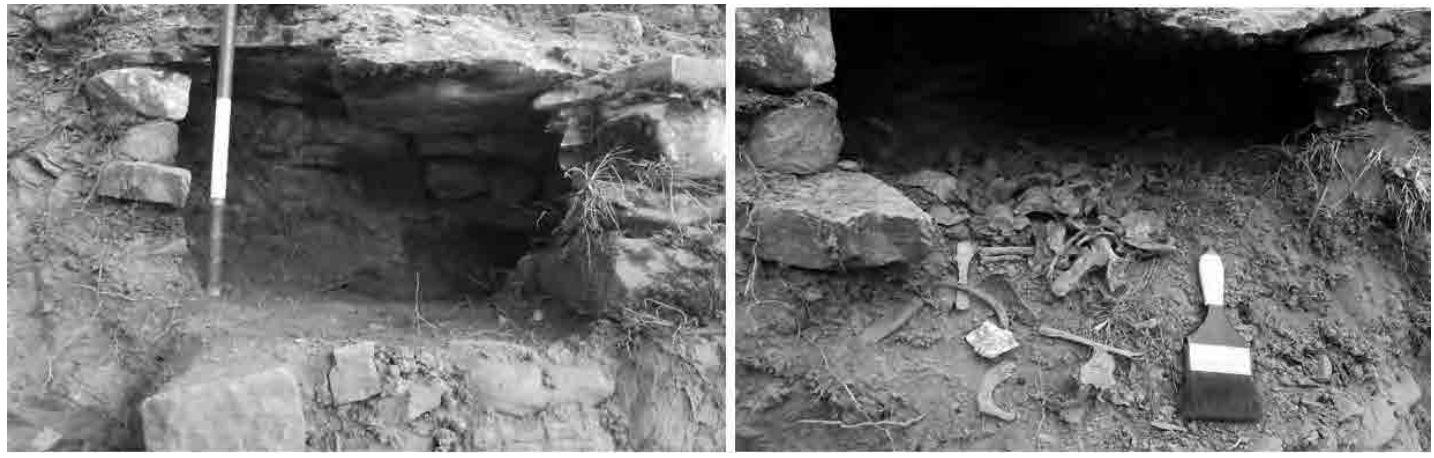

Figura 56 (izquierda): Vista de perfil de la Cámara Funeraria $N^{\circ} 02$, ubicada en la esquina suroeste del Muro $n^{\circ} 02$. Figura 57 (derecha): Vista de detalle del Contexto Funerario $N^{\circ} 03$.

Contexto Funerario 3: El contexto funerario $\mathrm{N}^{\circ} 3$ fue recuperado dentro de la cámara funeraria $\mathrm{N}^{\circ} 03$, se sitúa hacia el lado suroeste debajo del nivel del piso 1.

- Estructura funeraria: Está conformado por la cámara 3. Presenta una orientación suroeste a noreste, posee forma irregular ( $1.20 \mathrm{~m}$ de largo, $0.70 \mathrm{~m}$ de ancho y $0.45 \mathrm{~m}$ de profundidad). Esta estructura fue elaborada sobre la roca madre.

- Individuo: El contexto funerario 3 está conformado por un conjunto de restos óseos dispuestos sin orden aparente, los cuales en su mayoría se ubican hacia el lado noroeste de la cámara. Del material óseo humano recuperado se pudo distinguir huesos largos (fémur, tibia, peroné, etc); huesos cortos y vértebras, entre otros. Este contexto se encuentra disturbado. El estado de conservación del material óseo recuperado es regular, la mayor afectación es la humedad.

- Asociaciones: Dentro de este contexto se recuperaron diversas asociaciones: hacia el lado noreste se registró dos objetos óseos de forma ovalada con agujero central. Uno se encuentra entero y el otro está fragmentado. En el extremo sureste se recuperó un objeto lítico de forma rectangular de $5 \mathrm{~cm}$ de largo, $4 \mathrm{~cm}$ de ancho y $3 \mathrm{~cm}$ de grosor, presenta sus lados planos. En la parte central se recuperó un artefacto óseo de forma alargada, el cual presenta en un extremo un área cuadrangular plana y al otro extremo es semejante a una aguja; su acabado es pulido y corresponde a un tupu de hueso. En el extremo sureste se registró un objeto lítico de forma alargada de color azul verdoso. Asimismo, en el extremo norte se encontró también un objeto lítico alargado de color azul verdoso. Este último a nivel de la base de la cámara. 


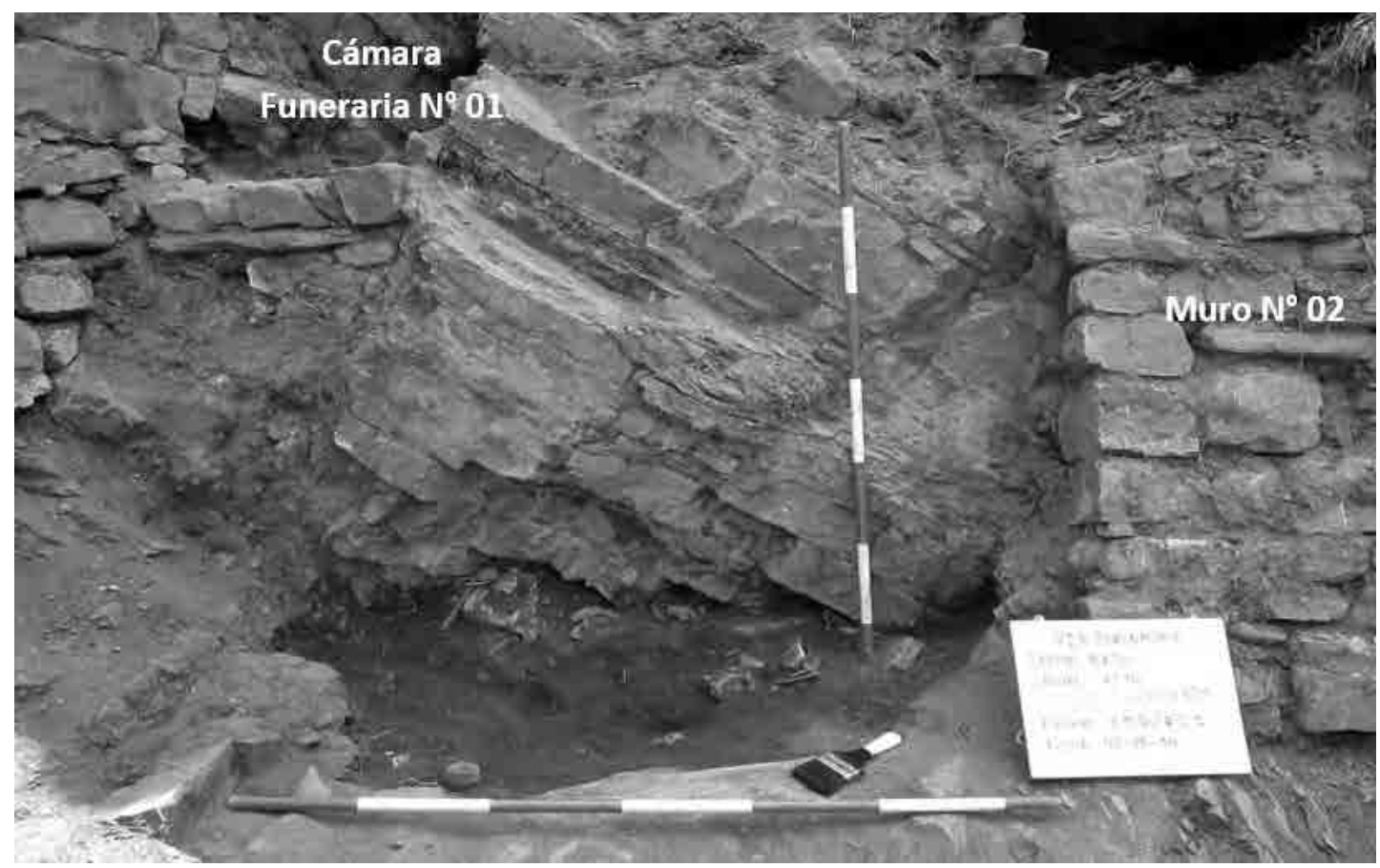

Figura 58: Vista de detalle de la Cámara Funeraria $N^{\circ} 03$.

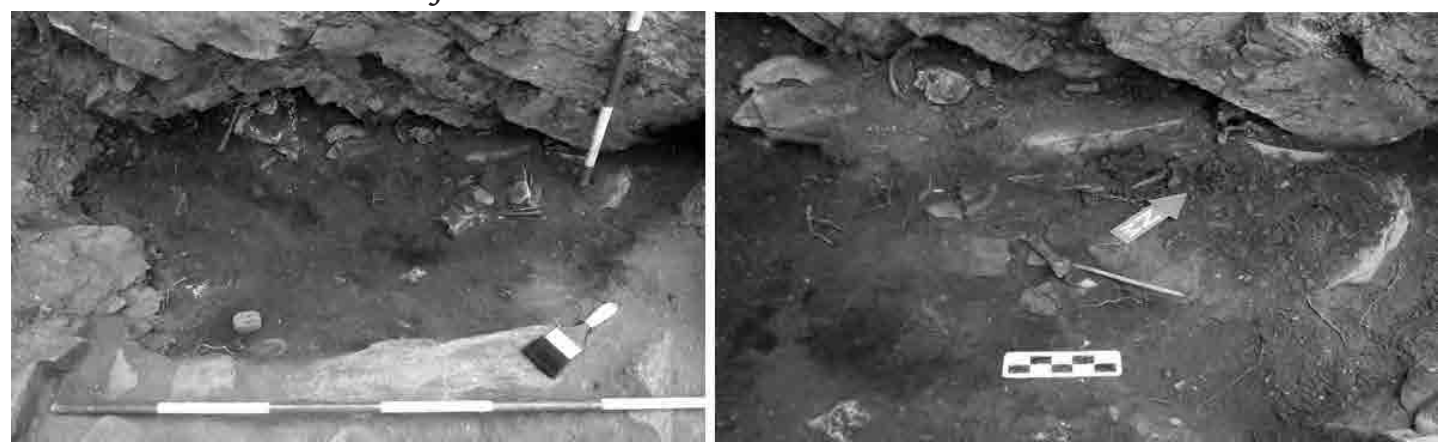

Figura 59 (izquierda): vista panorámica del Contexto Funerario $N^{\circ}$ 03. Figura 60 (derecha): Vista de detalle del objeto óseo

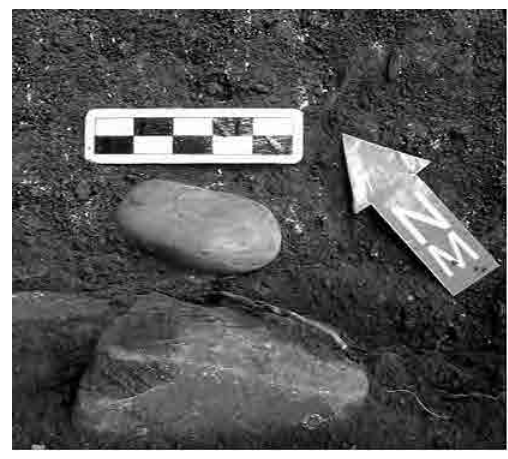
(tupu) recuperado en el C.F $N^{\circ} 03$.
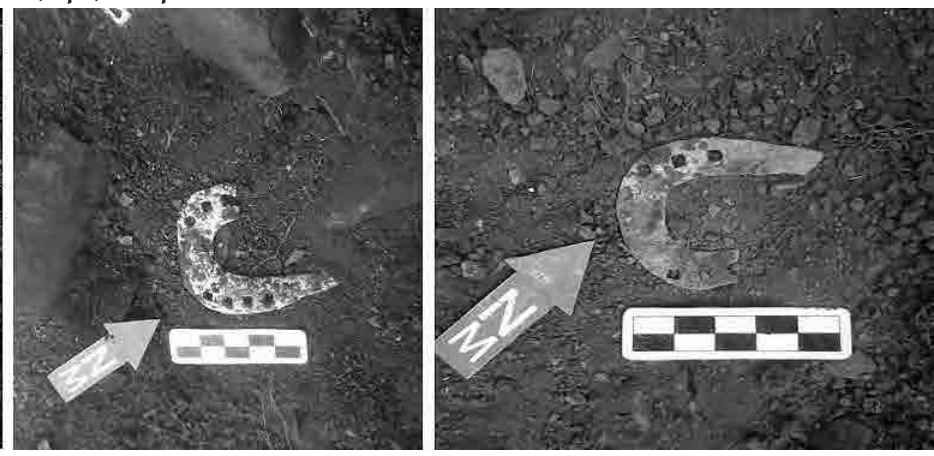

Figura 61 (izquierda): Vista de detalle del objeto lítico, recuperado dentro del C.F $N^{\circ} 03$. Figura 62 (centro). Vista panorámica de detalle del Hallazgo $\mathrm{N}^{\circ}$ 01, herradura. Figura 63 (derecha): Vista de detalle del Hallazgo $\mathrm{N}^{\circ} 02$ - herradura. 
Hallazgo $\mathrm{N}^{\circ}$ 01: El hallazgo $\mathrm{N}^{\circ} 01$ fue recuperado hacia el lado sureste de la unidad, dentro de la capa A. Está conformado por una herradura metálica de caballo del periodo de Transición Tawantinsuyu Colonial.

Hallazgo $\mathrm{N}^{\circ}$ 02: Se ubicó al noroeste de la unidad, a $1.00 \mathrm{~m}$ del límite noreste de la unidad y a $0.25 \mathrm{~m}$ de distancia del límite noroeste. Este hallazgo, dentro de la capa A, está conformado por otra herradura metálica de caballo.

\section{Piso 1}

El piso 1 (empedrado) se ubica hacia el lado suroeste, sureste y parte del lado noreste de la unidad, está conformado por piedras planas de diferentes dimensiones. El piso presenta un desnivel de $40^{\circ}$ aproximadamente hacia el sureste y fue elaborado para ser utilizado como un nivel de uso asociado a un espacio abierto.

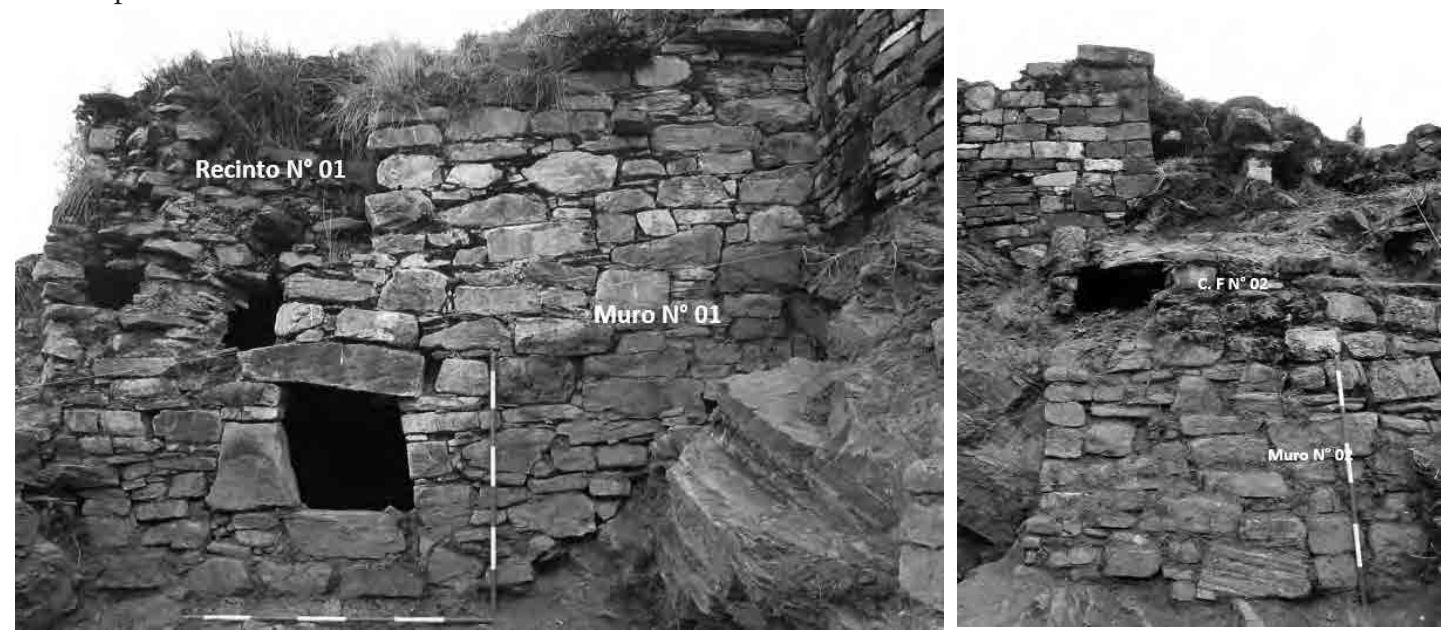

Figura 64: Vista panorámica del Muro $N^{\circ} 01$, ubicado hacia el suroeste de la Unidad. Figura 65: Vista de perfil del Muro $N^{\circ} 02$, ubicado hacia el noroeste de la Unidad.

\section{7.- UNIDAD 15}

Se encuentra situada en el sector bajo del sitio arqueológico emplazada sobre un terreno irregular, al suroeste de la unidad 13 y al oeste de la Unidad 14. Tiene 4x4 metros de dimensiones. La funcionalidad de esta unidad estaría relacionada a una actividad doméstica, teniendo en cuenta la gran cantidad de objetos líticos utilizados para la molienda (chancadores, etc.) de diversos alimentos. Según la distribución de las edificaciones, fue divida en dos subunidades: I ubicada al noroeste y la II ubicada al sureste.

Subunidad I: Fue cubierto por la capa superficial de origen natural y cubre a la capa A interpretada como el derrumbe de los muros 1, 2 y 3 que conforman el recinto 1. La capa A cubre al apisonado 2 y este cubre a la roca madre.

Subunidad II: La capa superficial cubría completamente a la subunidad y se caracterizaba por la vegetación natural de la zona, cubriendo a la capa A, conformada por el segundo momento de derrumbe del muro 6. La capa A cubre a la capa B, el primer momento de derrumbe del muro 6. La capa B cubre al apisonado 1, elaborado para nivelar la superficie irregular de la roca madre.

La secuencia estratigráfica identificada en la unidad es la siguiente: 


\section{Capa Superficial}

Esta capa presenta un color amarillo por la vegetación de la zona que se encuentra seca, de consistencia semicompacta y textura gruesa. Tiene un grosor de $0.05 \mathrm{~m}$. En esta capa se evidencia algunos fragmentos de material cerámico y material óseo. A este nivel de excavación se pudo identificar algunos elementos arquitectónicos en el lado oeste y esta abarca el 30\% de la unidad.

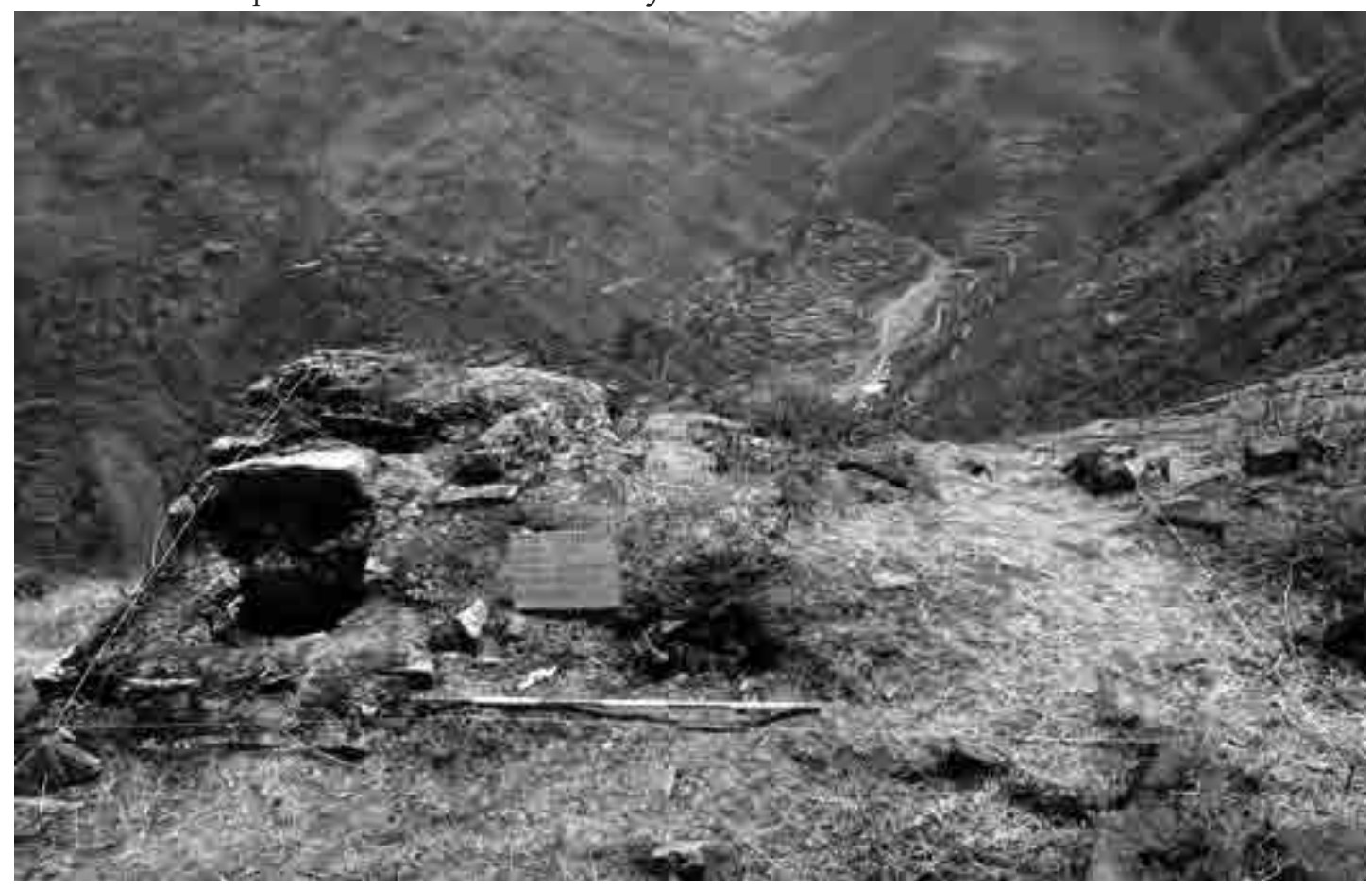

Figura 66: Vista panorámica de la capa superficial de la Unidad $N^{\circ} 15$, obsérvese la presencia de arquitectura hacia el lado oeste.

\section{Capa A}

Esta capa presenta color marrón, de consistencia semicompacta y textura gruesa. Está conformada en un $60 \%$ de tierra arcillosa y $40 \%$ de piedras trabajadas de $0.15 \mathrm{~m}$. a $0.40 \mathrm{~m}$. de largo. Los componentes culturales identificados en esta capa corresponden a inclusiones ocasionales de fragmentos cerámicos y material óseo. El retiro de la capa permitió observar claramente la arquitectura del lado oeste, la cual abarca el 50\% de la unidad. La capa A corresponde al derrumbe de los muros. Al nivel de esta capa se registraron el Contexto Funerario 1, los Hallazgos 1, 3 y 4.

Contexto Funerario 1: Fue identificado dentro de una cámara funeraria, en el lado oeste de la unidad.

- Estructura funeraria: Está conformada por la cámara de planta irregular, cuya orientación es de oeste a este. La estructura mide $0.80 \mathrm{~m}$ de largo, $0.50 \mathrm{~m}$ de ancho y $0.45 \mathrm{~m}$ de altura conservada; fue elaborada con piedras trabajadas de $0.15 \mathrm{~m}$ de a $0.20 \mathrm{~m}$ de largo unidas con argamasa. Su estado de conservación es malo, solo se mantiene el muro del lado oeste que conforma la cámara. 
- Individuo: El entierro corresponde a infantes de sexo indeterminado, dispuestos en el cual presenta una posición horizontal que abarca un área de $0.40 \mathrm{~m}$ de largo y $0.20 \mathrm{~m}$ de ancho, y cuya orientación es de suroeste a noreste. Es importante mencionar que el contexto se encuentra disturbado ya que los huesos no conservan su posición anatómica natural. Hacia el lado suroeste se puede observar parte del cráneo (lado frontal), hacia el lado sur se encuentran las costillas, hacia el lado noreste los huesos largos y finalmente, hacia el norte fragmentos del cráneo y también huesos largos.

- Asociaciones: Este contexto no presentó ningún tipo de asociaciones.

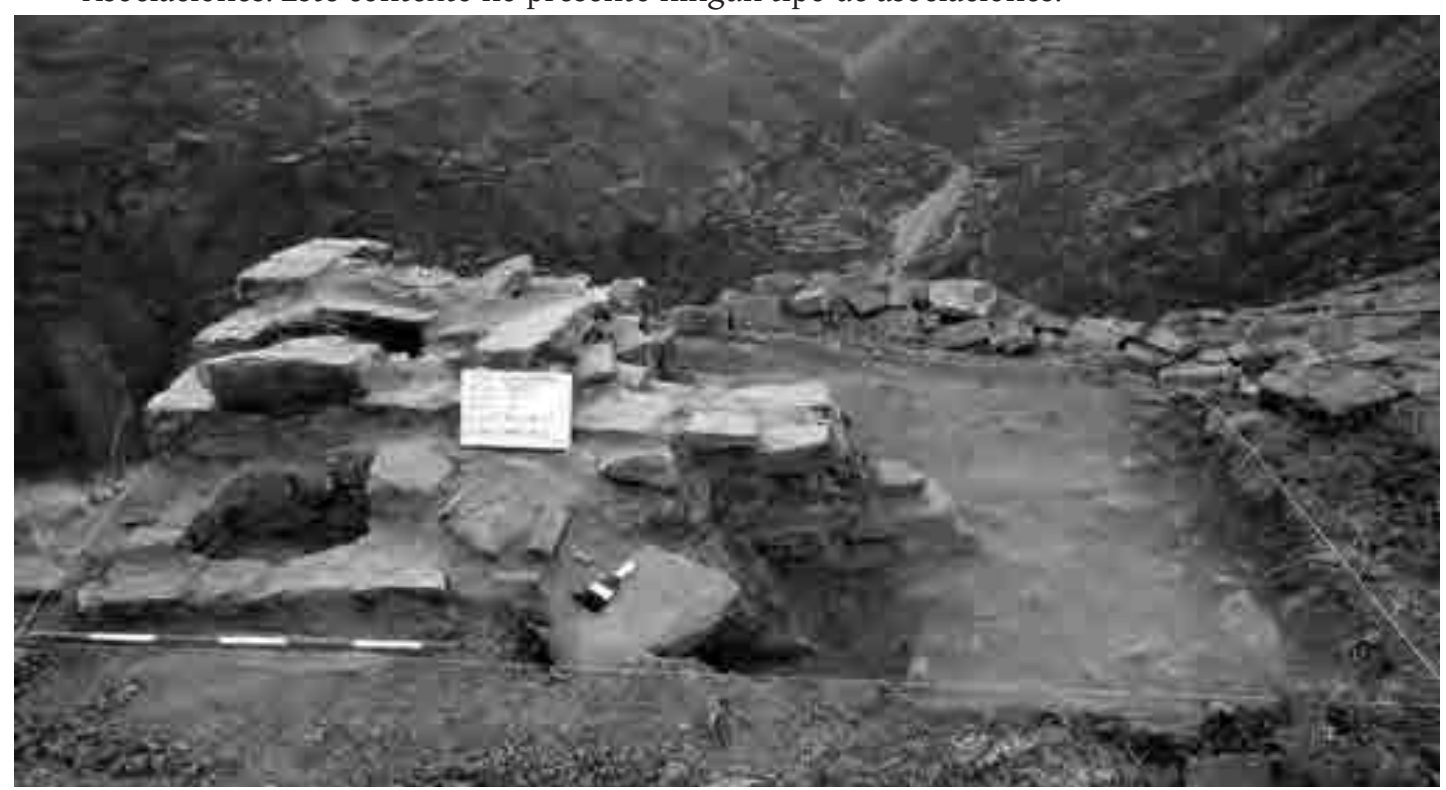

Figura 67: Vista panorámica de la capa A de la Unidad $N^{\circ} 15$.

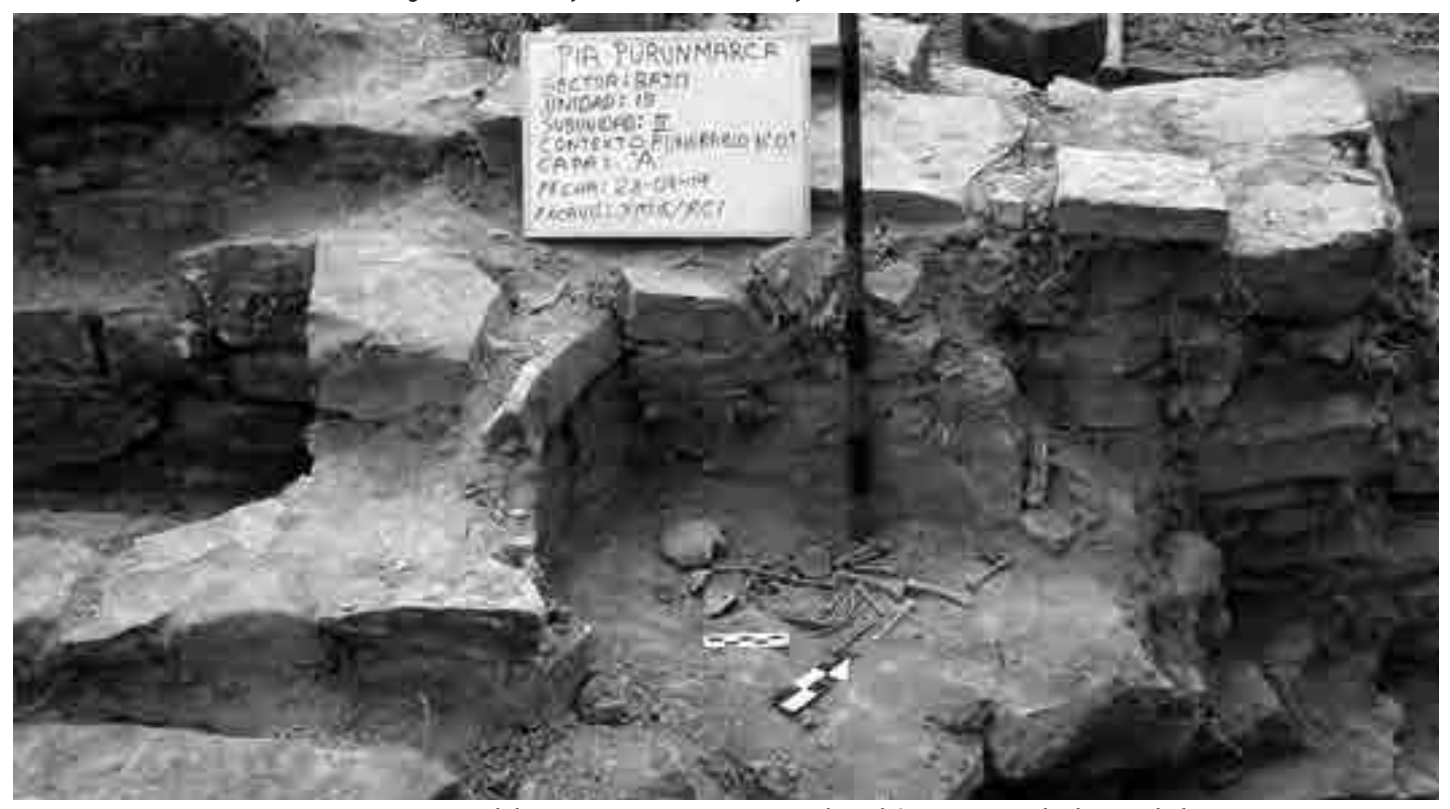

Figura 68: Vista panorámica del Contexto Funerario $N^{\circ} 01$ el cual fue recuperado dentro de la Capa A. 
Hallazgo 1: Se encuentra ubicado al lado sureste de la Subunidad II a 0.86m del límite de excavación del lado sur y a $0.88 \mathrm{~m}$ del límite del lado este. Fue recuperado dentro de la capa A. Está conformado por un artefacto lítico (chancador).
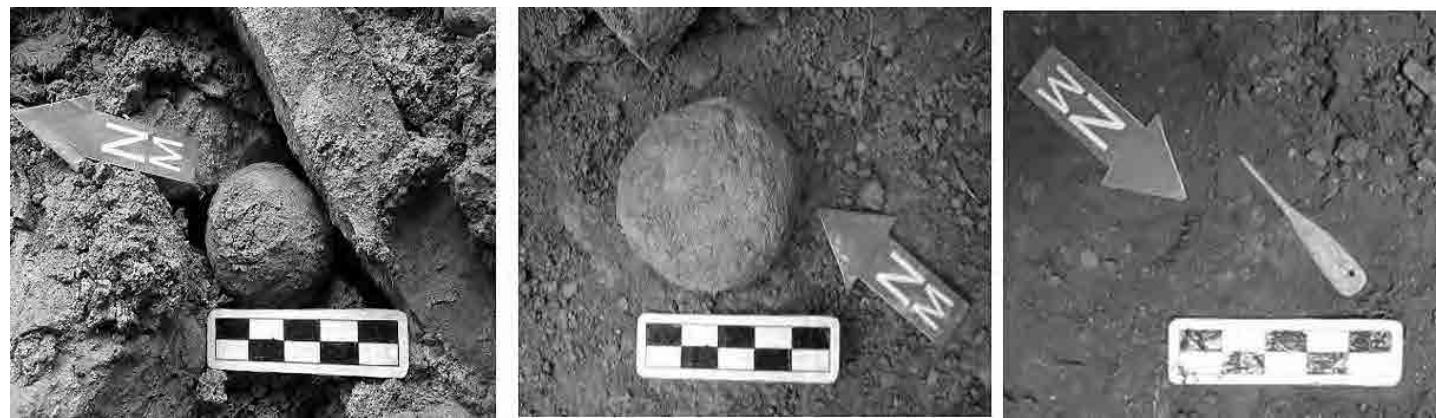

Figura 70 (izquierda): Vista de perfil del Hallazgo $N^{\circ}$ 01, correspondiente a un chancador. Figura 71 (centro): Vista de detalle del Hallazgo $n^{\circ}$ 03. Figura 72 (derecha): Vista de detalle del hallazgo $n^{\circ} 04$ - prendedor.

Hallazgo 3: Se ubica al lado este de la subunidad I a 1.41m al sur del muro 1. El hallazgo se encuentra situado sobre el Apisonado 2 y está cubierto por la capa A. Corresponde a un objeto lítico (canto rodado: chancador).

Hallazgo 4: Se encuentra ubicado al lado oeste de la cámara $\mathrm{N}^{\circ} 01$, a $0.11 \mathrm{~m}$ del muro 4 . El hallazgo fue recuperado dentro de la capa A. Está conformado por un artefacto óseo (prendedor).

\section{Capa B}

Esta capa fue registrada en la Subunidad II, presenta color beige por la tierra arcillosa que posee, consistencia semicompacta y textura gruesa. Los componentes culturales recuperados en esta capa están conformados por fragmentería cerámica y material óseo. Tiene un grosor de 0.42 metros. En esta capa se registró el Hallazgo 02.

Hallazgo 2: Se ubicó al lado sureste de la Subunidad II a 0.56m del muro 6 y a $0.20 \mathrm{~m}$ del límite de excavación del lado este. Se encuentra dentro de la capa B. Está conformado por un artefacto lítico (chancador).
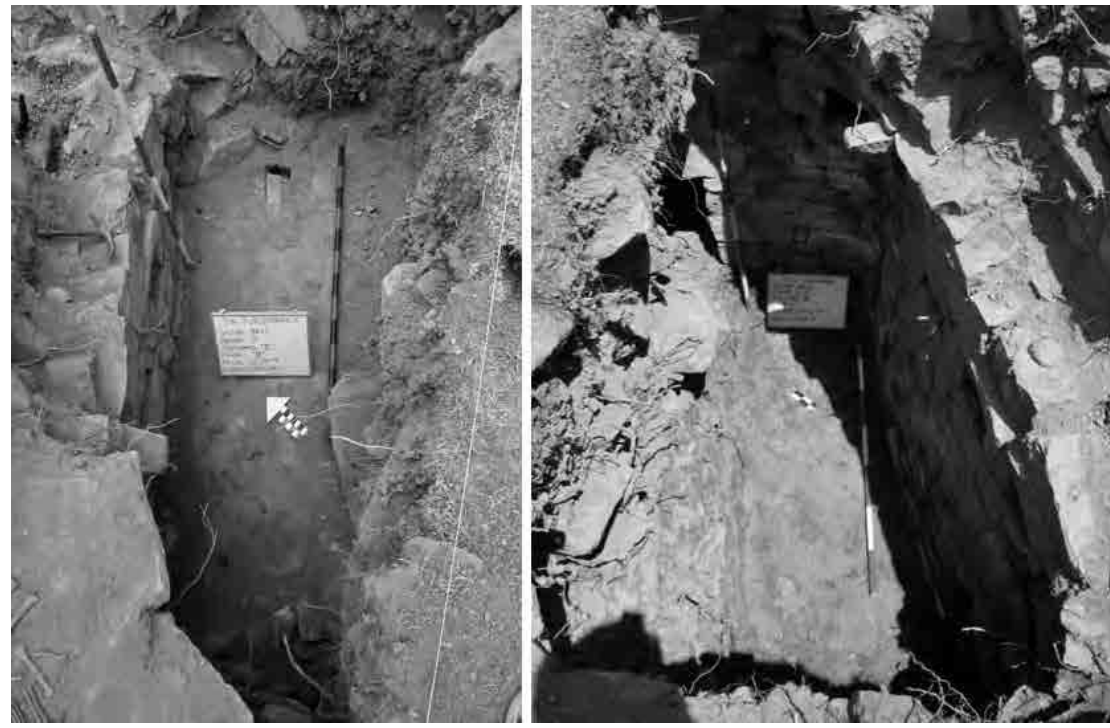

Figura 73 (izquierda): vista panorámica de la capa $B$, registrada en la subunidad II. Figura 74 (derecha): Vista panorámica del Apisonado $N^{\circ} 01$, registrado en la Subunidad II. 


\section{Apisonado 1}

Fue registrado en la Subunidad II, de color beige por la tierra arcillosa, consistencia semicompacta, $1.5 \mathrm{~cm}$ de grosor y textura fina. Está conformada por tierra arcillosa y grava fina. Esta capa no fue excavada. Hacia el extremo suroeste de la Subunidad II se realizó un cateo de 0.30m de lado en el cual se descubrió la roca madre debajo del apisonado 1, el cual fue realizado para nivelar la superficie irregular de la roca madre.

\section{Apisonado 2}

Se registró en la Subunidad I, de color beige, consistencia semicompacta y textura fina. Está conformada por tierra arcillosa y grava fina. Se observa inclusiones frecuentes de raíces. No fue excavada, fue elaborado para nivelar la superficie irregular de la roca madre.

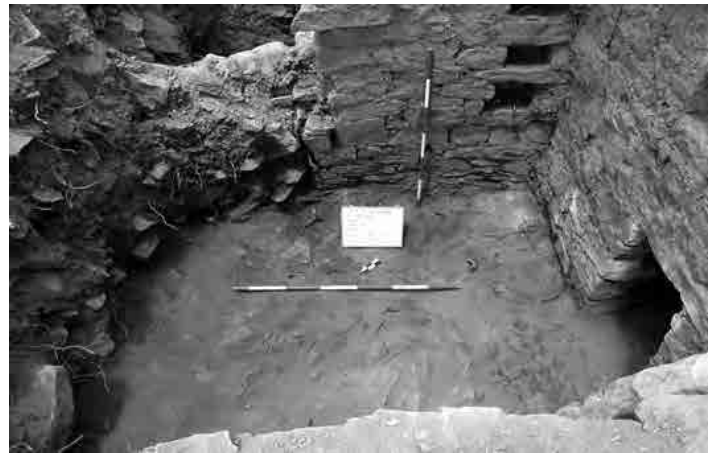

Figura 75: Vista panorámica del Apisonado $N^{\circ} 02$, registrado en la Subunidad I.

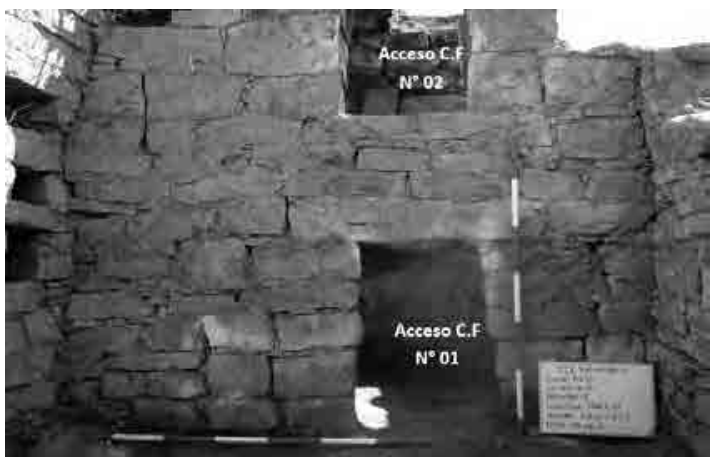

Figura 76: Vista de panorámica del Muro $N^{\circ} 02$, ubicado hacia el suroeste de la Subunidad I.

\section{ANÁLISIS DE LOS MATERIALES RECUPERADOS DE LOS CONTEXTOS FUNERARIOS}

Se realizó el análisis de los materiales recuperados de los contextos funerarios de Purunmarca, aplicando los métodos estándares de análisis de restos óseos (Buikstra y Beck 2006, Burns 2008, Ubelaker 2007). Los resultados de los análisis fueron los siguientes:

\section{1.- UNIDAD 2}

Contexto 1: Entre los restos óseos humanos se recuperó:

- Cuatro fragmentos de cráneo de bebé (menor de 12 meses de edad), 2 esternón de un individuo joven o adolescente; dos vértebras cervicales, 6 torácicas o dorsales, 3 lumbares; 4 costillas de un individuo joven y 1 coxis.

- De las extremidades superiores tenemos: 3 radios (2 derechos y un izquierdo) y 1 cúbito, el radio izquierdo mide $17.2 \mathrm{~cm}$, el cúbito izquierdo tiene $19.1 \mathrm{~cm}$. 5 carpos, 9 metacarpos de individuo adolescente.

- Extremidades inferiores: 3 fémures, 1 tibia derecha (completa de adulto mide $27.1 \mathrm{~cm}$ ) y 2 peronés: uno pertenece a un bebé y el otro derecho de adulto con diáfisis completa y sin epífisis que mide $24.1 \mathrm{~cm} ; 6$ tarsos adultos completos, 2 metatarsos de adolescente; y 15 falanges completos de mano y pies.

Como se aprecia los restos óseos corresponden a varios individuos, entre estos por lo menos un bebe de menos de un año de edad, un adolecente y dos adultos. No se ha podido identificar el sexo de los individuos.

Además, en el mismo contexto funerario se ha identificado en laboratorio los restos de una alpaca y un cuy, los cuales estaban en asociación a los individuos a modo de ofrendas: 
- Camélido: Alpaca (Lama pacos): 1 calcáneo derecho completo con infección en el borde lateral derecho que causó una osteomielitis, y una epífisis distal de húmero, chancado.

- Cuy (Cavia porcellus): 1 mandíbula derecha y 1 húmero no fusionado derecho.

Contexto funerario 1: Entre los restos óseos humanos se recuperó:

- Huesos de niños, por lo menos dos bebés menores de un año de edad. Se tiene 7 fragmentos de cráneo, 1 mandíbula de neonato, 6 costillas de bebé menor de 3 meses de edad, dos fémures, 1 tibia, 1 clavícula, 1 radio y 1 pelvis no fusionada (fragmento de íleon).

- Una mandíbula completa de género femenino robusto de 18-24 años de edad, 9 dientes "in situ" (ver figura); además 7 dientes sueltos del mismo individuo.

- 22 vértebras: 6 cervicales, 9 torácicas y 7 lumbares.

- 4 pelvis que pertenecen a dos individuos, uno a la misma mujer adulto-joven anterior y otro a un varón de 17-20 años de edad.

- 29 costillas que 23 son del adulto-joven y 6 de bebé menores de un año de edad.

- El sacro posee espina bífida oculta.

- Dos escápulas femeninas completas.

- 3 clavículas (2 derechos y 1 izquierdo femeninos).

- 1 esternón perforado en el cuerpo esternal con mango no fusionado de la mujer adulto-joven (ver figura).

- Extremidades superiores: 3 húmeros no fusionados en la epífisis proximal (19-24 años de edad), 2 cúbitos derechos de $19.1 \mathrm{~cm}$, un radio derecho de $17.4 \mathrm{~cm}$, y otro radio izquierdo fragmentado post-mortem. Entre los huesos de la mano hay 9 metacarpos y 3 carpos.

- Extremidades inferiores: dos fémures, el derecho mide $33.2 \mathrm{~cm}$ y el izquierdo con $33.3 \mathrm{~cm}, 1$ tibia izquierda completa mide $38 \mathrm{~cm}$ y 1 peroné de $25.9 \mathrm{~cm}$. Además, hay 2 rotulas. Entre los huesos del pie tenemos 8 tarsos y dos metatarsos. Incluyen 2 falanges. Un primer metatarso del pie izquierdo presenta una severa infección articular que causó porosidades en la cara que se inserta con el primer cuneiforme debido a un posible trauma (ver figura).

A partir del análisis de los óseos humanos se puede deducir que estos corresponden a por lo menos 4 individuos: dos bebes menores de un año de edad (uno de ellos menor de tres meses), dos individuos femeninos adulto-joven y un individuo masculino de entre 17-20 años de edad.
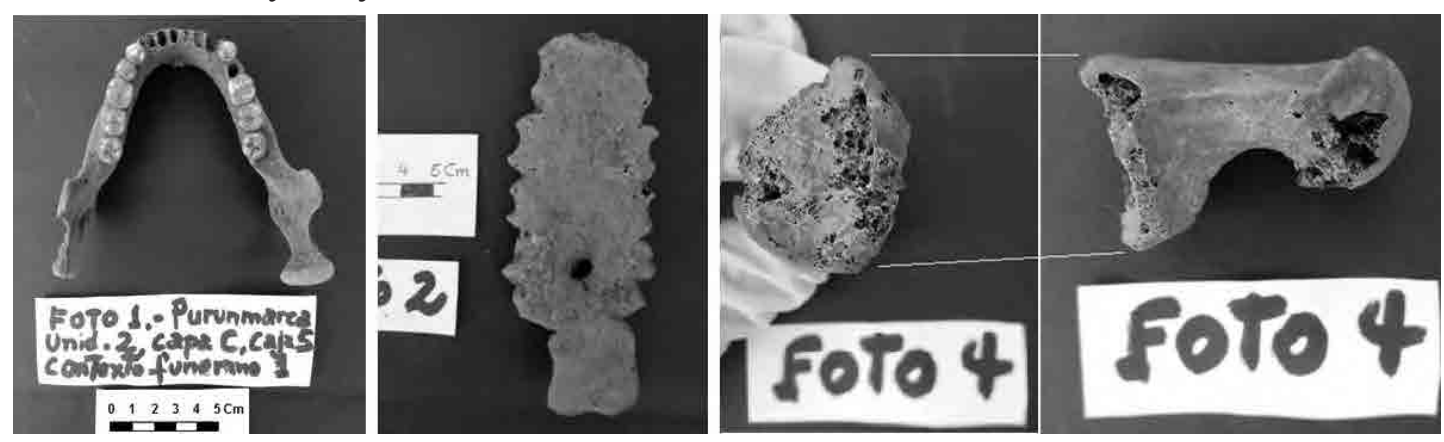

Figura 77 (izquierda): Mandíbula de individuo femenino adulto-joven (18-24 años de edad) de Purunmarca, dientes completos y alveolos abiertos caídos post-mortem. Figura 78 (centro-izquierda): Fosa esternal de individuo masculino adulto de Purunmarca. Figuras 79 y 80 (centro-derecha y derecha): Purunmarca, primer metacarpiano de mano izquierda de hombre adulto con infección osteoarticular en la cara con el escafoides (navicular). 

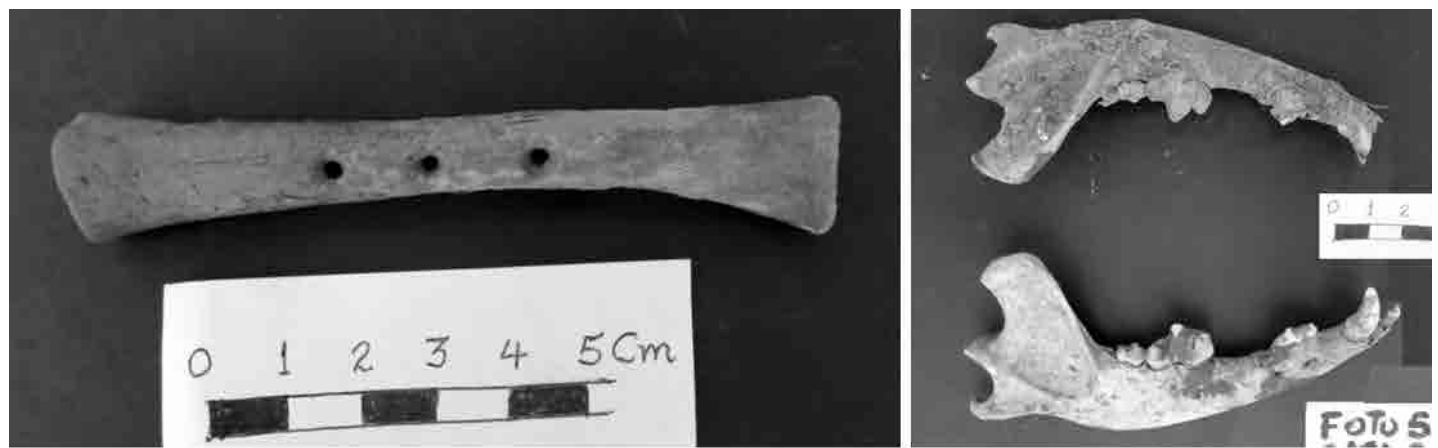

Figura 81 (izquierda): Flauta de camélido joven con 3 perforaciones hecho en el hueso de la tibia. Figura 82 (derecha): Purunmarca, Vichaycocha, mandíbulas de un perro viringo o kala-kala asociado a entierros humanos, ofrendas funerarias de psicopompo, C.F.2.

Entre los restos óseos recuperados se identificó en gabinete una flauta elaborada de tibia de camélido joven que mide $10 \mathrm{~cm}$ de largo y posee 3 hoyos pequeños y el borde desgastado en forma de bisel (ver figura). Además, se recuperó restos óseos de animales que estuvieron asociados a los óseos humanos a modo de ofrendas:

- Cuy (Cavia porcellus): 1 pelvis, 1 fémur y 1 tibia de un animal joven.

- Ayno (Fulica ardesiaca): 1 metatarso completo de ave de puna.

Contexto funerario 2: Entre los materiales identificados de este contexto figuran un atlas o C1 de alpaca joven (Lama pacos) con fractura longitudinal; y restos de un cánido o perro (Canis familiaris), perro chino, viringo o kala-kala:

- Un cráneo con fractura perimortem en el premaxilar izquierdo, golpe severo que afectó al molar superior izquierdo, hay dos mandíbulas completas de lado izquierdo y derecho, ausencia de los premolares con diastema que corresponde a un típico perro viringo (ver figura).

- Dos escápulas, izquierda y derecha completas; 23 vertebras: 7 cervicales, 12 torácicas y 4 lumbares; 19 costillas.

- 2 húmeros izquierdo y derecho quemados y fracturados en la epífisis proximal, 2 cúbitos izquierdo y derecho, 1 radio completo derecho de $15.20 \mathrm{~cm}$ de longitud y 6 metapodios.

Las evidencias muestran que este perro fue sacrificado de un golpe en la cabeza, para luego ser colocado en una pequeña cista asociada a algún contexto de evento constructivo o contexto funerario humano a modo de ofrenda.

\section{2.- UNIDAD 3}

Contexto funerario 1: Entre los materiales óseos hallados en los dos niveles del contexto funerario figuran:

Nivel 1: Se halló dos cráneos de niñas: una de 6 años de edad (ver figura) y otro de 11-12 años de edad con modelación cefálica del tipo "semi-alargado", con achatamiento de los parietales, huesos wormianos al lado derecho de la sutura lambdática y abultamiento de cresta nucal. Colocaron un disco de madera de 5-6cm de diámetro en el punto lambda para la modelación. El cráneo de 11-12 años de edad posee fractura lateral derecha peri-mortem. El cráneo de la niña de 6 años de edad tiene su mandíbula completa (ver figura). Además se recuperó en asociación a estos cráneos los siguientes 
huesos humanos: 17 fragmentos de cráneos de 2 bebés ( 5 del frontal, 9 parietales, 1 bula timpánica y 2 occipitales), 15 costillas de bebés, 31 vértebras no fusionadas, 2 escápulas (1 derecha y 1 izquierda), 1 clavícula izquierda, 2 pelvis (íleon), 4 diáfisis de húmeros de por lo menos 3 bebés, 2 radios y 1 cúbito; 2 metacarpos, 2 metatarsos; 2 fémures, 2 tibias, 4 peronés y 7 tarsos. En asociación se halló una Wichuña, instrumento textil elaborado de huesos largo de camélido joven, probablemente de alpaca, de metapodio con dimensión de $10.2 \mathrm{~cm}$ de longitud (ver figura). También se recuperó un piruro: disco óseo pulido de $4.2 \mathrm{~cm}$ de diámetro, elaborado de húmero de camélido joven, utilizado como instrumento textil (ver figura). Se recuperó también en asociación restos óseos de camélidos: 2 premaxilares fragmentados de cráneo de individuo joven, 3 vértebras cervicales, 3 diáfisis de húmeros, 1 diáfisis de tibia y 1 calcáneo chancado. También se recuperó los restos de un ukush o roedor pequeño (Phyllotis pictus): 1 mandíbula izquierda, 4 dientes incisivos, 2 vértebras torácicas, 2 escápulas, 1 húmero y 1 cúbito. Además, se identificó restos de jíquima (Pachirryzus sp.): raíz seca ligeramente cocida.
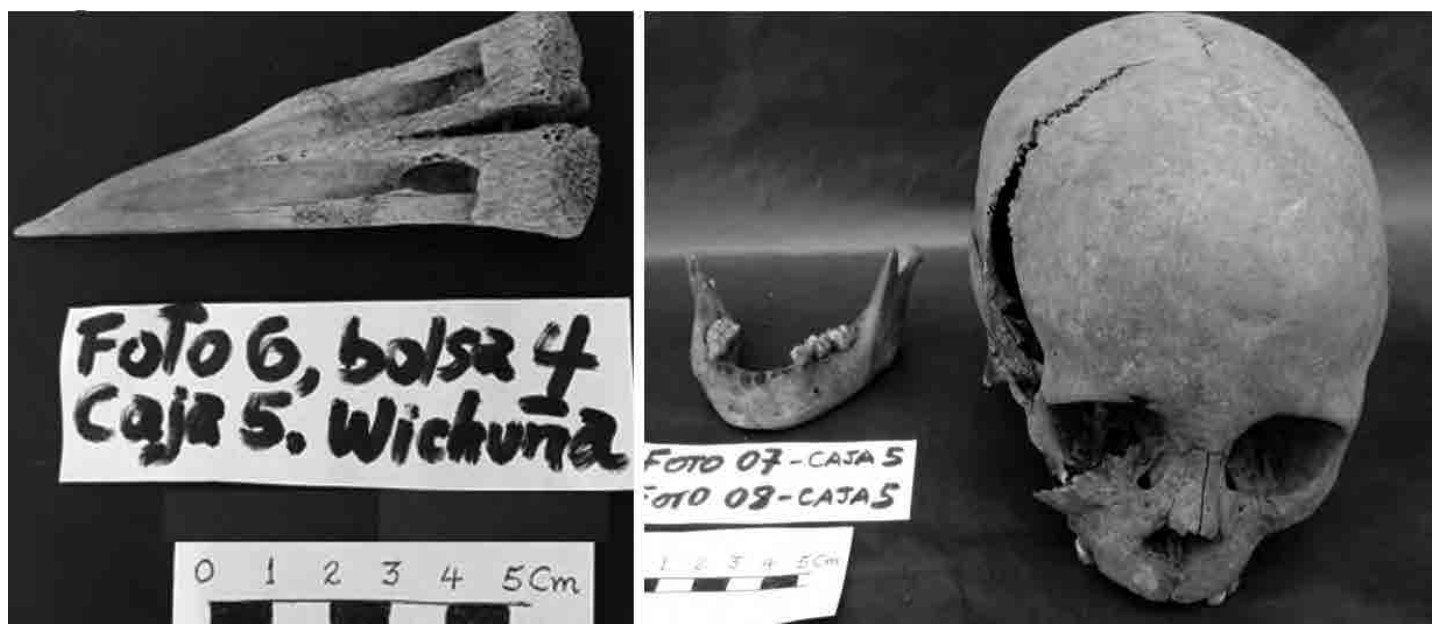

Figura 83 (izquierda): Wichuña de camélido joven. Instrumento textil. Figura 84 (derecha): Cráneo de niña de 6 años de edad con trauma severa en el hueso frontal y arco zigomático derecho. Modelado del tipo semi-alargado del tipo Atavillos.

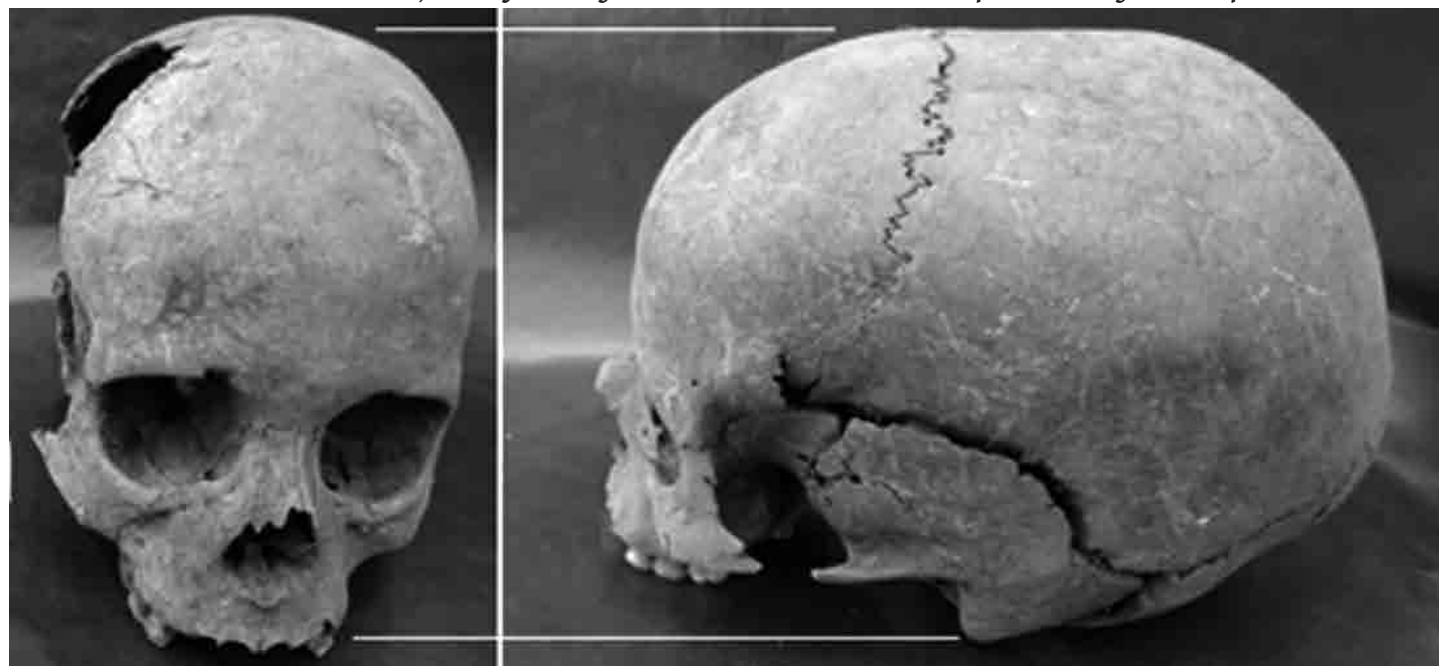

Figuras 85 y 86: Purunmarca, Vichaycocha, cráneo de niña de 11-12 años de edad con fractura nasal con modelación cefálica del tipo "semi-alargado". Exhibe hueso nasal achatada por trauma. 


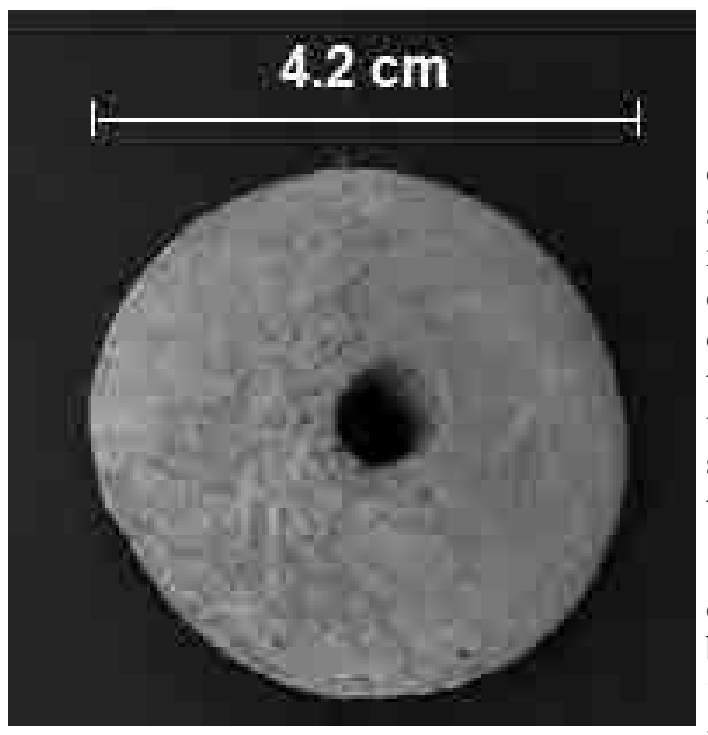

Figura 87: Instrumento textil de los pastores Atavillos, hallado en contexto funerario.

Nivel 2: Se recuperaron 3 cráneos: Dos cráneos completos de niñas de 7 años de edad, ambas presentan modelación cefálica semi-alargada con pronunciamiento de la cresta nucal. Tuvo una tablilla circular de $5 \mathrm{~cm}$ de diámetro a la altura del bregma, con huesos supernumerarios o wormianos en la sutura lambdática. El otro cráneo fragmentado es de un bebé de 3-5 meses de edad con mollera estaba siendo modelado del tipo "semi-alargado" semejante a las dos niñas anteriores.

Se recuperó también otros huesos procedentes de este segundo nivel: 4 fragmentos de cráneo de bebé; 3 mandíbulas de bebé y niño (2 femeninos y 1 masculino), con edades de 2 - 3 meses y 1 de 5-6 años de edad; pelvis (4 íleon, 1 pubis y 2 isquion) de bebés; 21 costillas de bebés; 42 vertebras, incluyen cuerpos vertebrales y arcos no fusionados; 4 clavículas ( 3 izquierdas y 1 derecho); 3 escápulas (2 derecho y 1 izquierdo) de niños; 3 esternones de bebés; 40 falanges de la mano y del pie; 9 metacarpos, 9 metatarsos; 1 sacro y 5 vértebras lumbares de niños de 7 años; 3 húmeros de niños; 2 radios (1 de bebé y otro de 5 años), 3 fémur, 1 calcáneo y 1 astrágalo de niño de 5 años de edad.

Separado de los huesos (hacia el sur) anteriormente descritos, se identificó los siguientes restos óseos humanos: 1 frontal de bebé (12 meses de edad), 60 costillas de niño (NMI = 3), además hay 32 vértebras de 3 niños de edad diferentes: 1 de 5 años, 2 de 12 meses; 3 clavículas completas de niños, 1 íleon derecho de neonato, 4 escapulas (2 derecho y 2 izquierdo) de niños; 3 húmeros de bebés de 1-2 años; 4 radios, 3 cúbitos, 1 fémur izquierdo de neonato; 4 tibias (1 niño y 1 neonato); 1 diáfisis de peroné; 2 falanges de mano de neonato; 3 epífisis distal de fémur no fusionado de 3 neonatos: uno menor de 3 meses de edad; otro de 8-9 meses y el tercero de 2-3 años de edad.

En asociación a estos restos óseos humanos se halló una aguja de hueso de camélido pulido de $5 \mathrm{~cm}$ de largo con su ojal. Además, estaban dos vértebras cervicales (C4 y C5), de llama adulta, 2 vértebras cervicales de alpaca joven, 2 esternones chancados y 1 epífisis distal de metacarpiano de alpaca joven no fusionado. También se recuperó los restos de dos Ukush o roedor pequeño: 1 cráneo, 1 mandíbula derecha; 2 tibias izquierda y derecha; 2 vértebras; 1 pelvis 1 sacro y 1 fémur izquierdo, correspondiente a un individuo; y 1 sacro y 1 fémur derecho completo, correspondiente al segundo individuo.

\section{3.- UNIDAD 7}

Contexto funerario 1: Corresponde al entierro múltiples de niñas pequeñas (un mínimo de cinco niñas). Se identificó los siguientes restos:

- 30 vértebras de 3 niñas; 5 clavículas (NMI= 3 niñas); 63 costillas de 2 individuos ( 3 niñas); 5 escápulas ( 3 derechas y 2 izquierdas); 7 sacros fragmentados y otras 14 de pelvis de 3 niñas; 5 húmeros (3 izquierdos y 2 derechos); 5 radios, 8 cúbitos ( 4 izquierdos y 4 derechos, con el NMI 4 niñas); 8 fémures (5 derechos y 3 izquierdos, NMI: 5 niñas); 10 tibias, a los cuales se agregan 5 epífisis proximal de fémur; 9 peronés; 2 distales de tibia no fusionadas, y dos proximales de húmeros; 6 calcáneos y 4 astrágalos; y 14 falanges de niñas. 
Además, se halló restos de una alpaca joven (Lama pacos) que habría formado parte de las ofrendas: 2 fragmentos de vértebras torácicas de alpaca joven de 1.5-2 años de edad, 1 rótula izquierda completa y 1 maleolo lateral izquierdo completo.

\section{4.- UNIDAD 9}

Contexto funerario 1: Como parte de este contexto se hallaron los restos de los siguientes individuos:

- Individuo 1: (C; final bajo el piso), Individuo masculino robusto de 35-41 años de edad, en posición decúbito lateral izquierdo con modelación cefálica del tipo semi-horizontal alargado con lóbulo en la cresta nucal y huesos supernumerarios (ver figura).

El cráneo está completo, con su mandíbula de fractura reciente, dientes desgastados por chacchado de coca, dientes incisivos ausentes en la mandíbula y en maxilar por trauma severo, dientes con hipoplasia del esmalte y altamente estresado.

Costillas completas; 2 clavículas; 3 fragmentos de esternón, 2 escápulas completas, 5 vértebras cervicales, 12 vertebras torácicas y 2 vértebras lumbares; 1 sacro de persona que ejecutaba mucho esfuerzo físico.

Extremidades superiores: 2 húmeros: el derecho tiene entesopatía del nivel 3 en la corredera bicipital. Talla: húmero derecho $28.8 \mathrm{~cm}$ con patina negra de grasa e izquierdo: $28.8 \mathrm{~cm}$, quemado con restos combustibles de plantas y animales. 2 cúbitos: uno izquierdo fragmentado y otro derecho completo que mide $24.0 \mathrm{~cm}$; 2 radios: el izquierdo tiene $22.0 \mathrm{~cm}$ y el derecho $22.2 \mathrm{~cm}$. Hay otra diáfisis de húmero de una mujer adulta; 9 carpos, 6 metacarpos.

Extremidades inferiores: Un fémur completo: derecho mide $39.6 \mathrm{~cm}$, izquierdo tiene $39.8 \mathrm{~cm}$ con hipervascularización en las rodillas, 2 peronés completos: el izquierdo mide $32.2 \mathrm{~cm}, 2$ tibias completas: el del lado derecho tiene: $33.3 \mathrm{~cm}$, y el izquierdo con $33.2 \mathrm{~cm}$; y otra diáfisis de tibia; 2 calcáneos, 2 astrágalos completos, 18 falanges, hueso del pie: 3 tarsos, 7 metatarsos y 3 falanges.

- Individuo 2: Corresponde a un individuo incompleto de sexo femenino joven, aunque con muestras en la pelvis de haber tenido 4 hijos (multípara). Los huesos que presenta son:

- Frontal en 4 fragmentos y parietal con modelación cefálica de individuo femenino joven, asociado a hoja de coca (Erythroxilum coca).

- 22 costillas completas; 14 fragmentos de vértebras (lumbar 4 con espondilolisis, con espina bífida oculta); 2 clavículas (con severa entesopatía en el borde inferior por cargar peso en el brazo izquierdo); 1 sacro con severa espondilolisis

- 2 Pelvis con evidencia de haber tenido 4 hijos

- Extremidades superiores: 2 húmeros, el izquierdo mide $28 \mathrm{~cm}$ el derecho y $27.8 \mathrm{~cm}$ el izquierdo; 9 fragmentos de cúbitos, uno completo mide $22.8 \mathrm{~cm}, 2$ radios. 1 metacarpo, 2 carpianos completos.

- Extremidades inferiores: 2 femur, uno mide $36.6 \mathrm{~cm}$; 2 tibias diáfisis erosionadas, 2 peronés; 2 calcáneos; 2 astrágalos adultos; 1 cuneiforme, 6 metatarsos completos con el pie derecho con callo óseo, fractura por trauma severo, 2 falanges del pie.

En asociación a estos dos primeros individuos, se hallaron algunos huesos de otra mujer (Individuo 3): 27 fragmentos de cráneo de adulto femenino con evidencia de chacchado de hoja de coca, dos húmeros, dos fémures, dos tibias, dos peronés, dos calcáneos, una pelvis y clavícula izquierda. También se halló los restos de dos bebes (podrían ser hijos del individuo 2: Individuos 4 y 5), uno de ellos femenino de 6 meses de edad: fragmentos de cráneo de bebés con modelación cefálica semi-alargado, 1 húmero diáfisis, 2 cúbito, 2 fémures y 3 tibias diáfisis; así como la mandíbula de un bebé de 3-6 meses 
de edad. Además, se encontró los restos de un individuo masculino adulto (Individuo 6): 1 húmero derecho $(29.3 \mathrm{~cm}), 1$ radio $(23.8 \mathrm{~cm}), 2$ fémures $(38.3 \mathrm{~cm}), 1$ tibia fragmentada, 2 peronés fragmentados.

En otro lado de la estructura funeraria, en la parte superior se halló la concentración de restos óseos humanos de varios individuos, los cuales por su cercanía se desarticularon y juntaron (tres individuos femeninos, dos masculinos y un neonato):
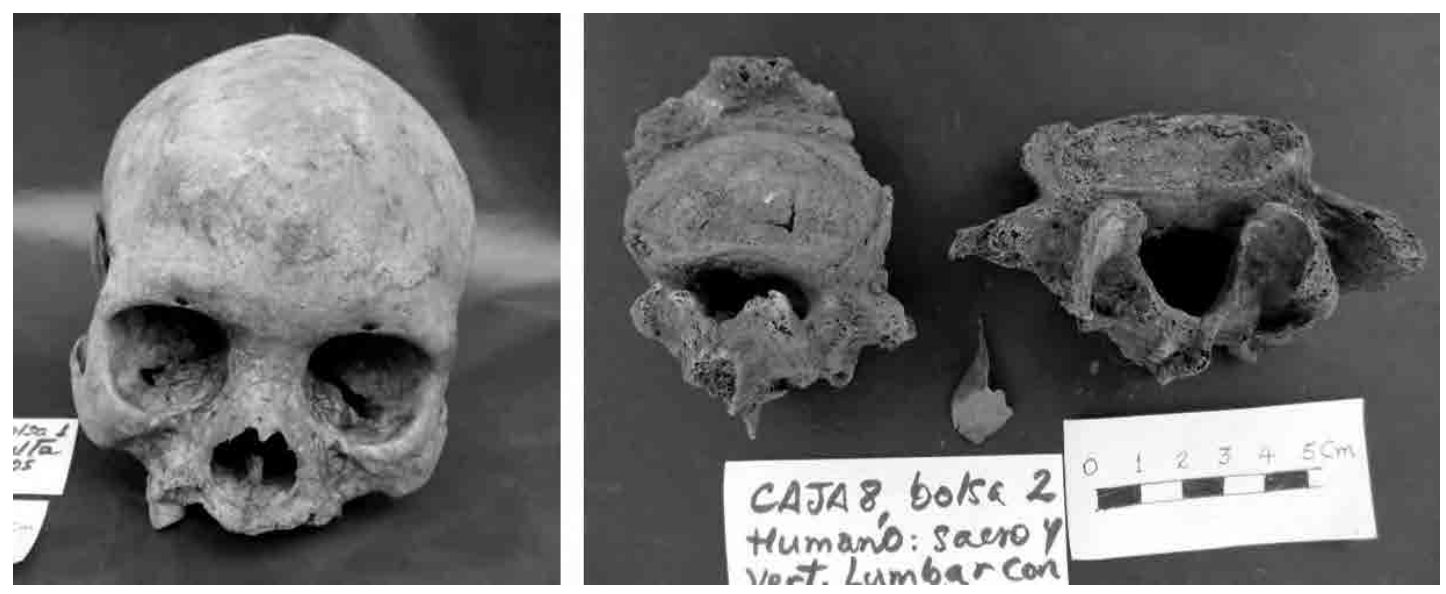

Figura 88 (izquierda): Cráneo masculino robusto de 35-41 años de edad con modelación cefálica del tipo semi-horizontal alargado con lóbulo en la cresta nucal (individuo 1). Figura 89 (derecha): Vértebra lumbar L5 y sacro con espondilólisis de femenino robusto. Exceso de fuerza cargando peso o luchas personales (individuo 2).

- Cráneo con metopismo (sutura en el hueso frontal), 6 mandíbulas (mujer de 18-24 años de edad, otra mujer de 20-30 años, 2 varones de 30-40 años con fuerte desgaste dentario, uno femenino de 50 años y un neonato femenino).

- 8 fragmentos de pelvis (6 fragmentos de mujeres jóvenes y 2 fragmentos de hombres adultos), 2 sacros masculinos adultos, 4 vértebras torácicas adultos, costillas (21 fragmentados), 3 esternones ( 2 femeninos y 1 masculino), 2 clavículas completas derechas (1 masculino y 1 femenino), 4 escápulas ( 2 derechos y 2 izquierdos) de adultos.

- Extremidades superiores: 1 húmero derecho de bebé, 1 cúbito izquierdo adulto, 7 radios (3 masculinos y 4 femeninos), uno de ellos tiene fractura tipo Parry por luchas interpersonales (ver figura 90).

- Extremidades inferiores: Dos fémures jóvenes erosionados, 5 peronés adulto ( 3 masculinos y 2 femeninos), un cuneiforme adulto.
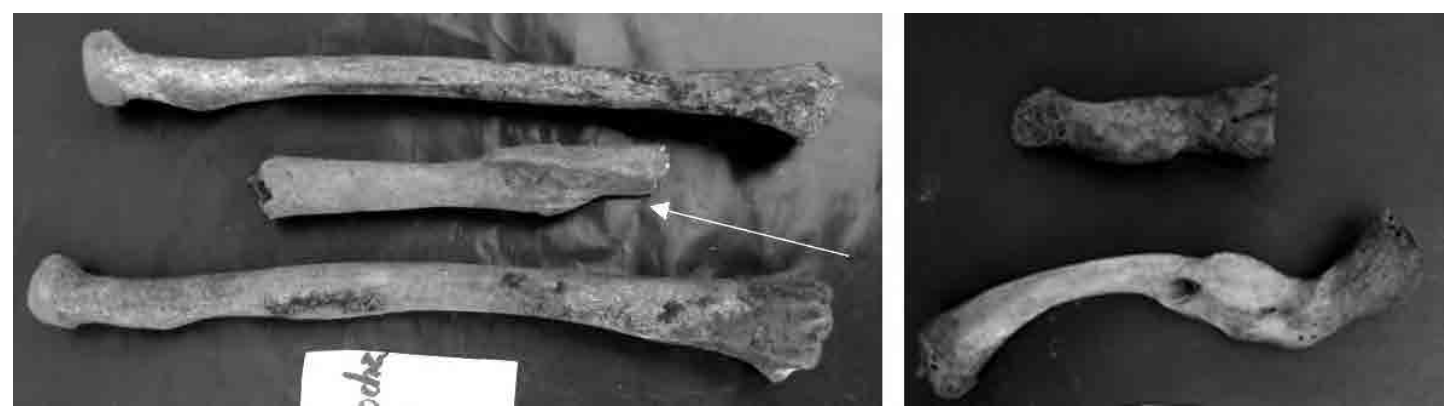

Figura 90 (izquierda): Fractura de Parry en el hueso radio izquierdo de individuo femenino adulto del centro. Figura 91 (derecha): Metacarpo de mano derecha con callo óseo (arriba) y clavícula derecha de masculino adulto-joven (abajo) afectada por golpe. 
En la parte inferior de la estructura funeraria se identificaron abundantes restos óseos a manera de osario. Al parecer los huesos eran sacados cada cierto tiempo y pintados a modo de ofrendas con cinabrio, para luego ser regresados a la estructura funeraria. Se recuperó múltiples huesos humanos de diversos individuos (bebés, jóvenes y adultos) con periostio pintados con cinabrio. Hay los restos de trece individuos adultos y siete niños y bebes (una mujer adulta robusta con cinabrio) en este contexto:

- Cráneo: 11 fragmentos de frontal y parietal joven, otros 15 fragmentos de cráneo, 4 mandíbulas ( 2 bebés y 2 adultos femeninos), 2 fragmentos de mandíbulas (de niño 10-12 años de edad). 7 fragmentos de cráneo de un adulto femenino de 30 años de edad, sin dientes incisivos anteriores; 10 dientes de adultos, 1 de ellos posee hipoplasia severa; 1 hioides de adulto fusionado.

- Columna vertebral: 25 cervicales, 40 torácicas y 27 lumbares (7 con espondilólisis), 11 fragmentos de pelvis, 14 pelvis (5 adultos y 2 bebes; 7 femeninos), 3 sacros de individuos jóvenes, 118 costillas de individuos adultos-jóvenes, 4 clavículas de adultos-jóvenes (una de estas presenta fractura osificada), 3 escápulas (2 derechos y 1 izquierdo); 7 esternones de individuos jóvenes o adulto-joven robusto (dos de femenino), una clavícula derecha fracturada y osificada; dos clavículas (una izquierda de femenino adulto); 6 omóplatos (3 derecho y 3 izquierdos adultos)

- Extremidades superiores: un metacarpo de mano derecho con otro callo óseo de masculino adulto-joven (ver figura), 6 húmeros chancados en la diáfisis, otros 16 húmeros (8 izquierdos y 8 derechos que pertenecen a 5 hombres y 3 mujeres adultos), un radio distal de mujer adulta con cinabrio, seis radio de joven; 4 diáfisis de cúbito de mujeres jóvenes, 7 cúbito (4 derechos y 3 izquierdos); 25 metacarpos de adulto, 10 falanges de la mano, y 22 carpos completos.

- Extremidades inferiores: 9 rótulas completas de individuos adultos, 14 fémur completos (3 individuos masculinos y 4 femeninos: 5 izquierdos y 4 derechos; uno de mujer adulta derecho con hipervascularzación proximal y distal), 7 fragmentos de fémur de 3 individuos jóvenes y 1 neonato; 7 tibias diáfisis, 13 tibias (7 izquierdos y 6 derechos), 3 epífisis proximal de tibia femenino; 12 peronés diáfisis de jóvenes, 8 astrágalos completos de adulto (mujeres), 10 calcáneos adultos y jóvenes (5 izquierdo y 3 derecho), 17 cuneiformes de individuos adultos, 6 tarsiano de adulto joven, 41 metatarsos completos, 12 falanges del pie.

- Bebes: 1 maxilar, 1 mandíbula (3 meses de edad), 21 costillas, 5 pelvis (íleon), 2 escápulas (1 izquierdo y 1 derecho), 9 húmeros (5 derechos y 2 izquierdos), 1 clavícula derecha, 7 radios, 5 cúbitos, 11 fémures de bebés ( 4 derecho y 4 izquierdo), 6 tibias y 1 peroné.

En asociación a estos últimos restos se halló óseos de animales:

- Camélidos: una vértebra torácica de alpaca joven, una mandíbula de llama adulta (de 8-10 años de edad) posiblemente depositado como psicopompo (ofrenda), 3 vértebra cervical adulto y 1 pelvis izquierda de llama adulto femenino. Además, se identificó: tres vértebras ( 1 cervical, 1 torácica, 1 lumbar de animal joven), 3 costillas diáfisis jóvenes, 3 fragmentos de pelvis, 1 sacro, 1 diente molar inferior adulto (5-6 años de edad), 2 epífisis proximal de húmeros, 1 metapodio joven, 3 falanges (2 de llama y 1 de alpaca); 1 hioides, 2 húmeros distales de animal tierno (menor de 1 año de edad), 1 calcáneo derecho completo de posible alpaca de 1 año de edad; 1 primera falange de camélido adulto, posible llama. 2 metapodíos de alpaca joven y 1 primera falange fracturada.

- Cérvidos: una vértebra torácicas joven y 2 esternón de animal joven.

- Cuy: Una pelvis izquierda y una tibia izquierda joven.

De igual manera se identificó otro osario asociado al contexto funerario 1 donde se hallaron los restos de 7 individuos: 
- 6 fragmentos de cráneo con sinus frontalis pequeños y pares, con modelación cefálica semi-alargada con lóbulo nucal, masculino joven de 14-16 años de edad; 1 mandíbula derecha fragmentada de masculino de 20-25 años de edad. 30 fragmentos de cráneo, 3 fragmentos de mandíbulas de mujer robusta, con edad mayor de 24 años de edad.

- 2 pelvis izquierdas de un masculino de 18-24 años y otro es mayor de 30 años de edad; 3 pelvis masculino (de un individuo de 25-30 años y otro de 35-40 años de edad), 7 fragmentos de costillas, de individuo adulto joven; 74 vértebras: 20 cervicales, 37 torácicas y 20 lumbares (de adulto joven), 7 escápulas derechas masculino ( 2 completo y 5 fragmentados), 1 sacro masculino (de 18-24 años de edad, ha ejecutado mucho esfuerzo físico). 7 clavículas adultas; 12 fragmentos de pelvis de adultos. 107 costillas, todas fragmentadas. 1 esternón: un mango o manubrio de un masculino joven.

- Extremidades superiores: 6 húmeros adultos (2 derechos y 1 izquierdo), el largo del húmero derecho masculino mide $31.0 \mathrm{~cm}$. de longitud, y el otro de $30.0 \mathrm{~cm}$., adulto-joven; 4 cúbitos fragmentados post-mortem y 5 radios de adultos de 35-40 años de edad. 17 metacarpos, 10 falanges de adulto.

- Extremidades inferiores: 13 fémures (4 izquierdos y 6 derechos: seis individuos masculinos), hay un fémur masculino de $44.4 \mathrm{~cm}$. de largo y otro fémur izquierdo de $42.2 \mathrm{~cm}$. también masculino; 9 tibias (4 izquierdos y 5 derechos, de 4 masculinos adultos de 25-30 años de edad, una con fractura proximal post-mortem), 5 tibias (derecha masculina mide $36.8 \mathrm{~cm}$, y otra tibia izquierda masculino mide $35.2 \mathrm{~cm}$.), 9 peronés ( 2 derechos y 1 izquierdo de adultos); 3 rótulas completas ( 2 jóvenes y 1 adulto); 13 astrágalo, 19 cuneiformes y 6 calcáneo (izquierdo masculino adulto); 1 metacarpo y 21 metatarsos completos de individuo adulto, 1 falange adultos.

- Bebés: 5 íleon de 3 bebés: uno de 1-2 meses de edad, otro de 2-3 meses de edad y el tercero de 5-6 meses de edad; 10 costillas, 1 clavícula izquierda completa, 5 húmeros (4 derecho y 1 izquierdo), 1 cúbito, 3 peronés, 1 fémur, 7 tibias (4 derechos y 3 izquierdos).

En asociación a estos últimos se identificó los siguientes restos óseos animales que formaban parte de las ofrendas:

- Camélido: 1 maxilar izquierdo, 1 mandíbula izquierda y 2 molares de una llama joven y otro de alpaca adulta; 5 vértebras: 2 cervicales, 2 torácicas y 1 lumbar de 2 individuos (uno joven y otro adulto); 3 pelvis de individuo tierno ( 1 año de edad o "tuí"), 1 costilla izquierda y 1 calcáneo izquierdo de joven tierno, 1 escápula derecha adulta de llama, 1 hioides de llama robusta, 3 húmeros de jóvenes, epífisis proximal, 3 radio-cúbitos (de 2 jóvenes), 3 diáfisis de fémures de tiernos; 5 tibias ( 2 jóvenes y 3 tiernos), 2 metapodios jóvenes-tiernos, 1 astrágalo derecho joven de 1.5-2 años de edad, 4 primeras falanges de tuí o "yearling".

- Cérvido: 1 esternón: cuerpo esternal.

- Cuy: 1 pelvis derecha joven.

En la parte superior de la estructura funeraria se recuperó los restos de varios individuos, recuperándose 5 cráneos modelados de adultos robustos y 2 mandíbulas:

- El Cráneo 1 pertenece a un individuo masculino de 25-30 años de edad, robusto, con fractura nasal y desvío del vómerante-mortem, fractura del arco zigomático izquierdo peri-mortem; hay un severo golpe que rajó en forma vertical e inclinado el parietal izquierdo. Posee dientes completos, bien dispuestos, chacchaba hojas de coca y han caído los incisivos y caninos delanteros post- mortem. Exhibe modelación cefálica del tipo semi-alargado con glabela robusta, hay una elevación bregmática que recorre toda la sutura sagita en forma horizontal y paralela a la horizontal de Frankfurt y tiene cresta nucal ligeramente pronunciada (ver figura). 


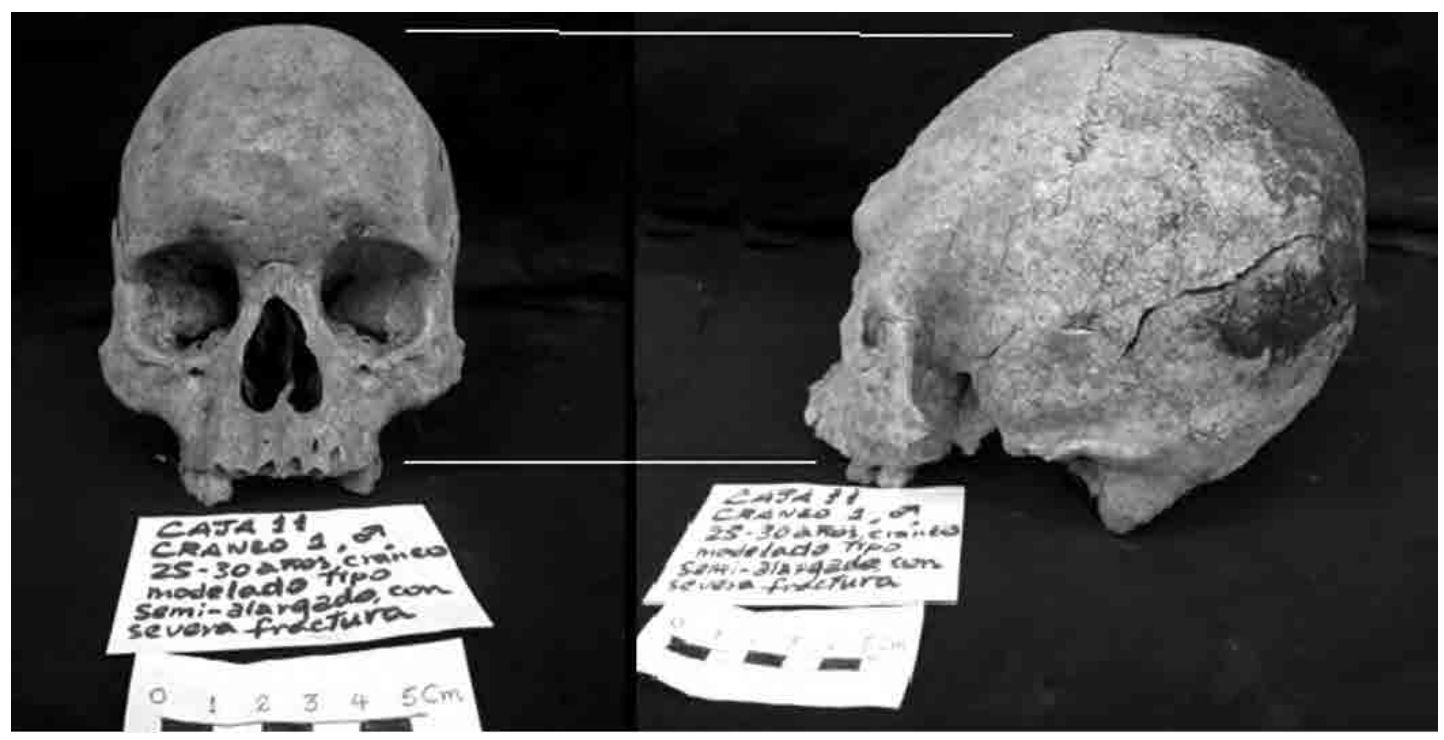

Figura 92: Cráneo 1, masculino adulto 25-30 años de edad de Purunmarca, Vichaycocha. Con modelación cefálica Semi-alargada o tipo Atavillos con severa fractura del hueso nasal y vómer desviado a la derecha por diversos traumatismos faciales.

- El Cráneo 2 es de un individuo de sexo masculino de 25-30 años de edad, robusto, fractura nasal y desviación del vómer hacia la izquierda ante-mortem, con modelación cefálica vertical y elevación bregmática. Es un individuo serrano debido a los surcos meníngeos medios profundos, con fractura perimortem severa del hueso occipital (porra o maza) de $4 \mathrm{~cm}$ de diámetro de forma oval con el fin de la extracción y consumo de la masa encefálica, con dientes completos y sanos, los cuatro incisivos superiores han caídos post-mortem (ver figura).

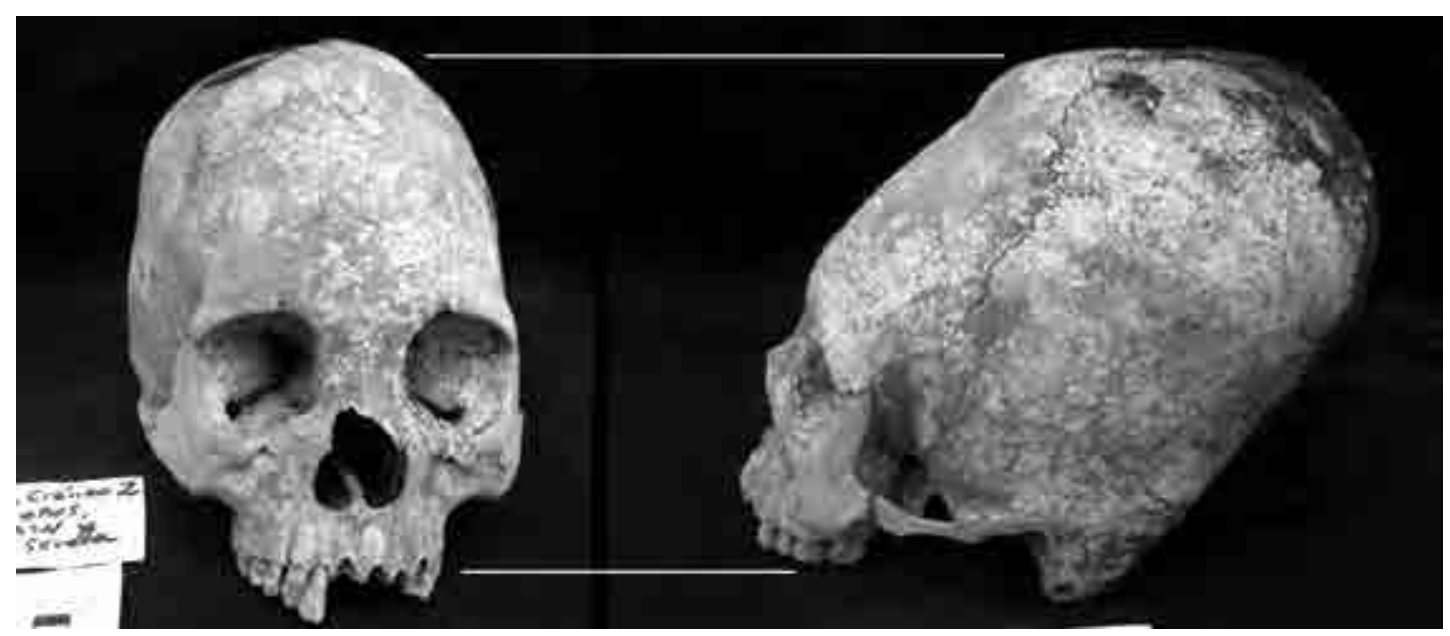

Figura 93: Cráneo 2, masculino adulto robusto de 25-30 años de edad de Purunmarca, Vichaycocha. Con modelación cefálica vértico-bregmático o tipo Wari con severa fractura del hueso nasal y vómer desviado a la izquierda por diversos traumatismos faciales.

- El Cráneo 3 de individuo masculino de 25-30 años de edad, el esplacnocráneo está totalmente destruido peri-mortem, con modelación cefálica vértico-bregmática pronunciada. Posee una fractura peri-mortem de $11 \mathrm{~mm}$ de forma triangular e inclinada de $10.5 \mathrm{~mm}$ de longitud (ver figura). 


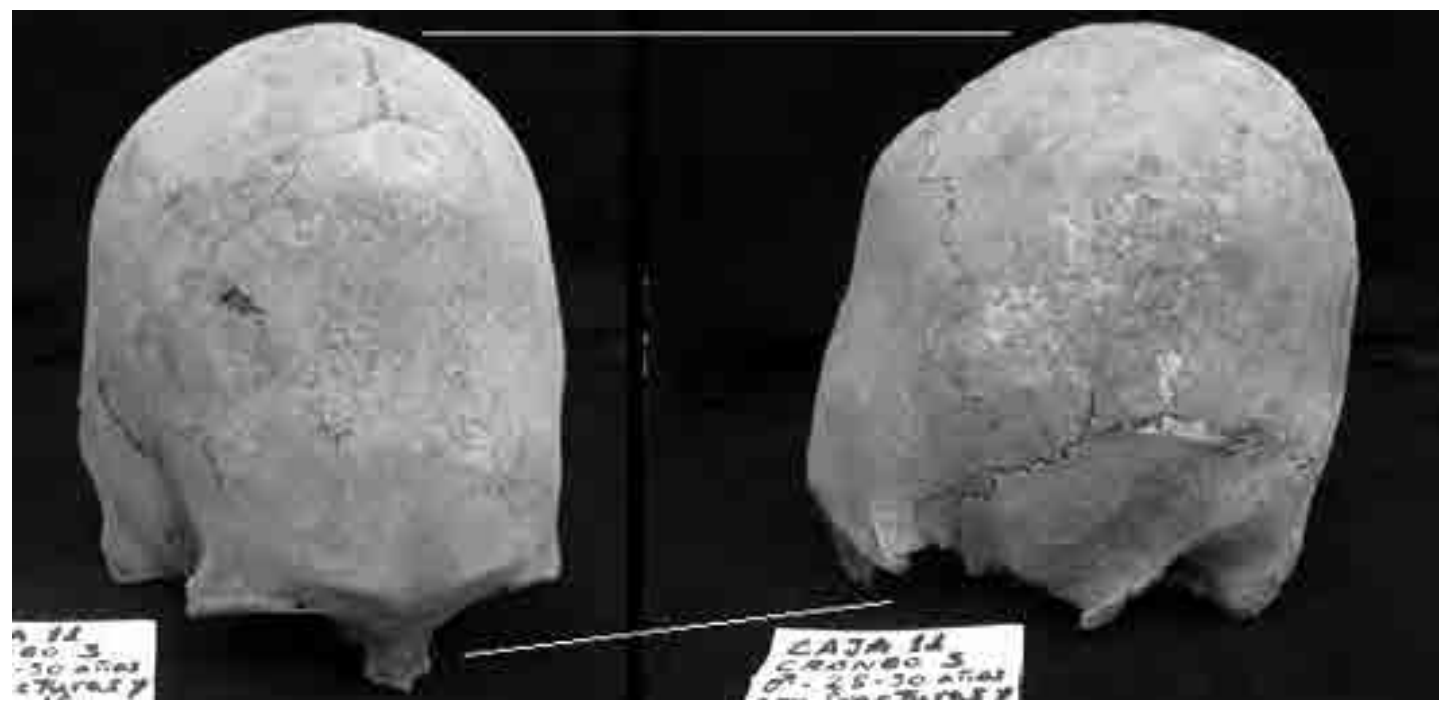

Figura 94: Cráneo 3, masculino adulto robusto de 25-30 años de edad de Purunmarca, Vichaycocha. Con modelación cefálica vértico-bregmático o tipo Wari con severa fractura del hueso nasal y destrucción del esplacnocráneo. Nótese la hendidura en el frontal derecho por punta ósea en lucha interpersonal.

- El Cráneo 4 es de un individuo femenino de 35-40 años de edad, robusto con destrucción post-mortem el esplacnocráneo, posee modelación cefálica del tipo vértico-bregmático y con la presencia de la fosita aimara, otra fosa en la parte inferior del occipital y pequeña depresión de 15 por $5 \mathrm{~mm}$ en el parietal izquierdo (ver figura).
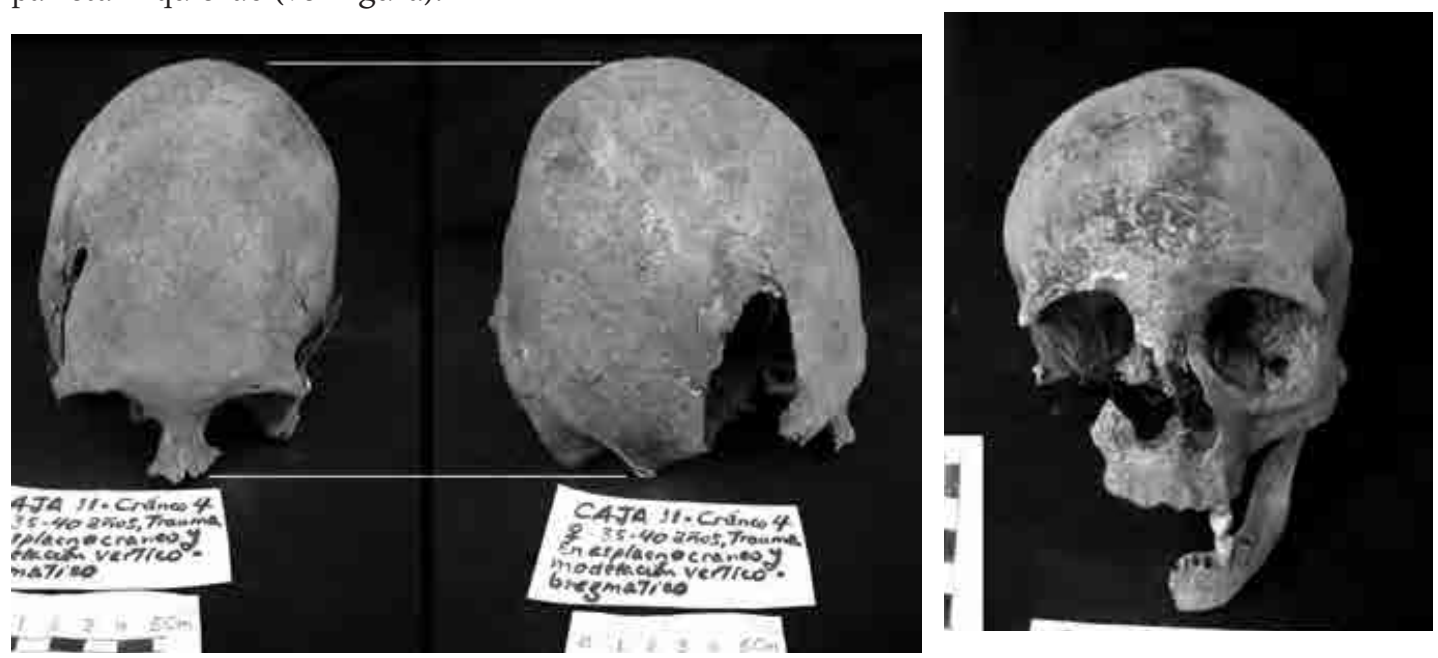

Figura 95 (izquierda): Cráneo 4, femenino adulto robusto de 35-40 años de edad de Purunmarca, Vichaycocha. Con modelación cefálica vértico-bregmático o tipo Wari con severa fractura del frontal y parietal derecho y esplagnocráneo. Figura 96 (derecha): Cráneo 5, femenino adulto robusto de 30-35 años de edad de Purunmarca, Vichaycocha. Con modelación cefálica semi-longitudinal o semi-horizontal (propio de los Atavillos) con cal en el esplagnocráneo

- El Cráneo 5 es de un individuo femenino de 30-35 años de edad, grácil, con fractura en el esplagnocráneo post-mortem y modelación cefálica semi-longitudinal o semi-horizontal (propio de los Atavillos) con cal en el esplagnocráneo, asimismo el diente canino con cal (llipta) está desgastado por consuno de hojas de coca (ver figura). 
Para tener una mejor comparación entre los cráneos modelados de Purunmarca se han realizado algunas mediciones y el índice cefálico (Tabla $N^{\circ} 1$ ).

\begin{tabular}{|c|c|c|c|c|c|}
\hline $\begin{array}{l}\text { Medidas craneométricas } \\
\text { adultos }\end{array}$ & $\begin{array}{c}\text { CRANEO } 1 \\
M\end{array}$ & $\begin{array}{c}\text { CRANEO } 2 \\
M\end{array}$ & $\begin{array}{c}\text { CRANEO } 3 \\
M\end{array}$ & $\begin{array}{c}\text { CRANEO } 4 \\
\mathrm{~F}\end{array}$ & $\begin{array}{c}\text { CRANEO } 5 \\
\mathrm{~F}\end{array}$ \\
\hline $\begin{array}{l}\text { Long. Máx del crảneo (gl- } \\
\text { op) }\end{array}$ & $163 \mathrm{~mm}$ & $163.0 \mathrm{~mm}$ & $160.7 \mathrm{~mm}$ & $169.2 \mathrm{~mm}$ & $167.2 \mathrm{~mm}$ \\
\hline $\begin{array}{l}\text { Ancho Max. del cráneo (eu- } \\
\text { eu) }\end{array}$ & $128.1 \mathrm{~mm}$ & $126.2 \mathrm{~mm}$ & $130.2 \mathrm{~mm}$ & $127.5 \mathrm{~mm}$ & $122.5 \mathrm{~mm}$ \\
\hline Indice celálico & 78.58 & 77.42 & 81.02 & 75.35 & 73.26 \\
\hline
\end{tabular}

Tabla $N^{\circ}$ 1.- Medidas craneométricas de los 5 cráneos analizados de Purunmarca, Vichaycocha, alto Chancay.

- El Cráneo 6 posee pátina de cinabrio en el rostro. Se trata de un individuo masculino, con apófisis mastoidea y arcos zigomáticos finos (posiblemente de la élite), de 35-40 años de edad, con fractura peri-mortem en el arco zigomático derecho y gran destrucción del esplagnocráneo, además posee modelación cefálica del tipo Atavillos o semi-alargada con lóbulo en la cresta nucal (ver figura).

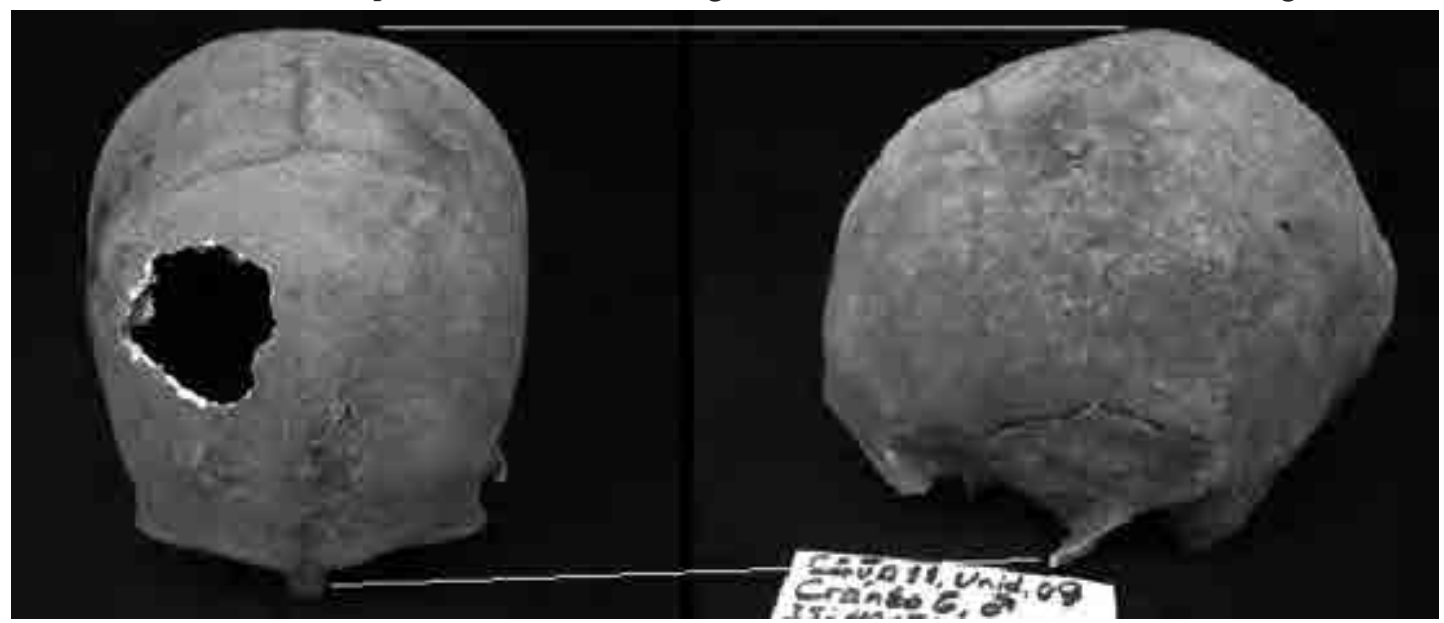

Figura 97: Cráneo 6, masculino adulto 35-40 años de edad de Purunmarca, Vichaycocha. Con modelación cefálica semi-alargada o tipo Atavillos con destrucción post-mortem del esplagnocráneo y frontal derecho.

- El Cráneo 7 exhibe fracturas en el parietal izquierdo post-mortem. El foramen magno muy reducido. Se trata de un individuo femenino robusto de origen serrano, con glabela pronunciada adulto, 30-35 años de edad, con hendidura de $1.83 \mathrm{~cm}$ con cal, que causó la fractura de todo el esplagnocráneo.

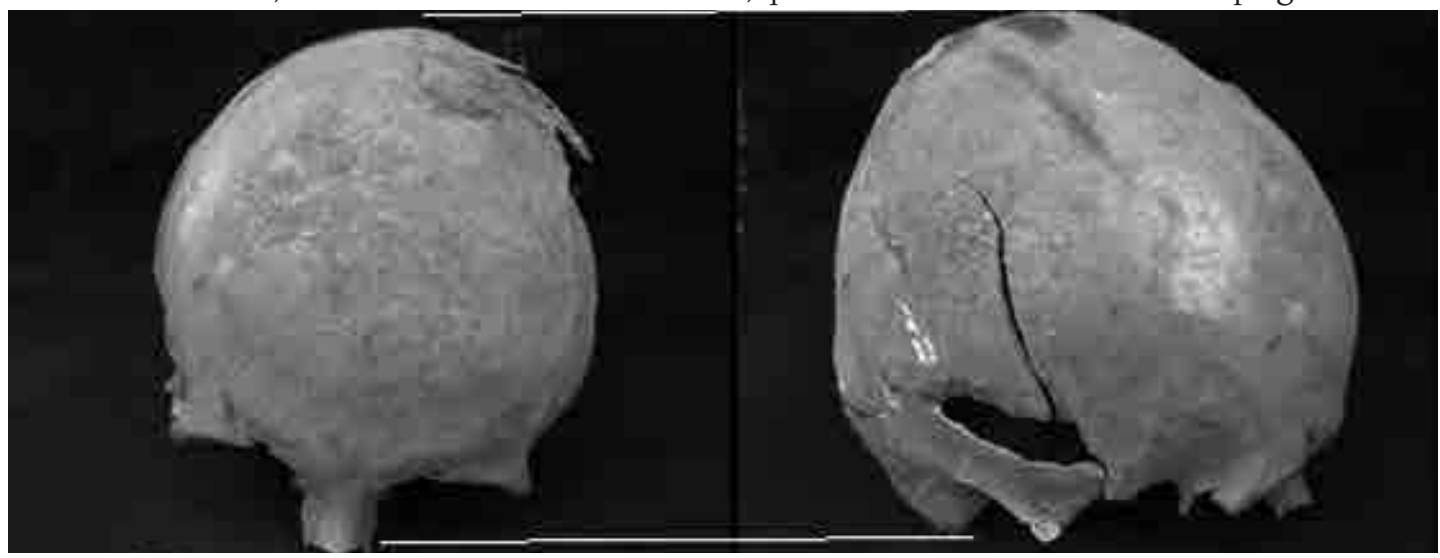

Figura 98: Cráneo 7, femenino adulto 30-35 años de edad de Purunmarca, Vichaycocha. Con modelación cefálica semi-alargado o tipo Atavillos con destrucción post-mortem del esplagnocráneo. 
Presenta modelación cefálica del tipo Atavillos o semi-horizontal (ver figura).

- El Cráneo 8 corresponde a individuo femenino robusto de 35-40 años de edad, con modelación cefálica del tipo vértico-bregmático, además presenta meningocele por inflamación constante de la nariz por traumatismo, ausencia de dientes pero con alveolos abiertos (ver figura).

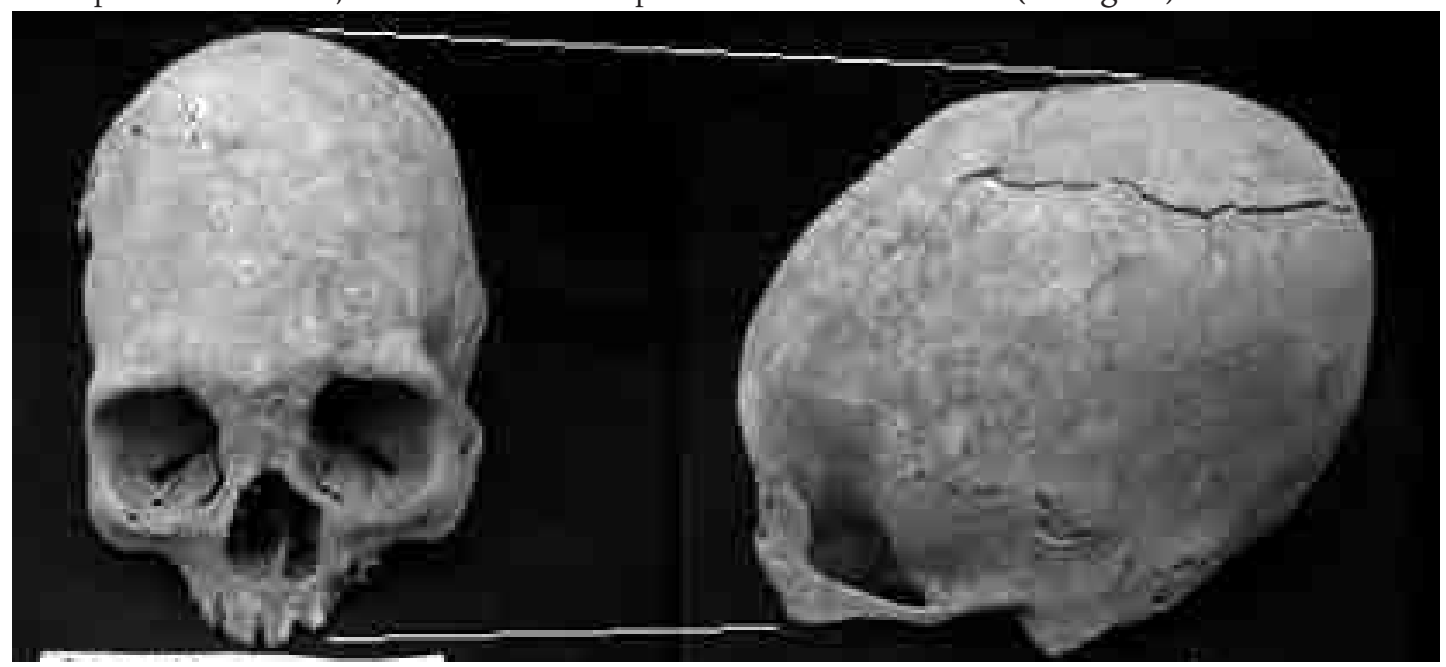

Figura 99 (izquierda): Cráneo 8, femenino adulto 35-40 años de edad de Purunmarca, Vichaycocha. Con modelación cefálica Vertico-bregmático y meningocele naso-frontal. Figura 100 (derecha): Cráneo 10, femenino adulto de 16-18 años de edad con severa infección ocular por leishmaniasis y criba orbitalia de Purunmarca, Vichaycocha, con modelación cefálica vértico-bregmático.

- El Cráneo 9, masculino de 30-35 años de edad modelación cefálica semi-horizontal, fractura post-mortem, y peri-mortem del arco zigomático izquierdo.

- El Cráneo 10 pertenece a una mujer de 16-18 años de edad, robusta con criba orbitalia, todo muy fragmentado, de origen serrano. Existe una severa infección en la parte izquierda ocular y arco zigomático izquierdo con modelación cefálica tipo semi-horizontal o Atavillos, posible leishmaniasis ocular (ver figura).

Además hay: 5 fragmentos de cráneos de neonatos (NMI=2) y 15 fragmentos de cráneo de adultos (NMI=3); 4 maxilares de adultos con dientes. 3 mandíbulas completas: 1 masculino adulto de 35-40 años de edad, coqueros, abundante consumo de proteína animales y quinua; otro adulto-joven femenino de 18-24 años de edad con caries en segundo molar inferior derecho - cara distal- y una niña de 2-3 años de edad. 1 pelvis femenino adulto-joven (íleon). 1 fémur izquierdo de bebé de 1-2 años de edad y 1 cuneiforme completo de masculino adulto. En la tabla 2 se observa las mediciones craneométricas del segundo grupo (Tabla $\mathrm{N}^{\circ} 2$ ).

\begin{tabular}{|l|c|c|c|c|}
\hline \multicolumn{1}{|c}{ Medidas craneométricas } & \multicolumn{1}{c}{$\begin{array}{c}\text { CRANEO 6 } \\
\text { M }\end{array}$} & $\begin{array}{c}\text { CRANEO 7 } \\
\text { F }\end{array}$ & $\begin{array}{c}\text { CRANEO 8 } \\
\text { F }\end{array}$ & $\begin{array}{c}\text { CRANEO 9 } \\
\text { M }\end{array}$ \\
\hline Long. Máx. del cráneo (gl-op) & $171.4 \mathrm{~mm}$ & $159.1 \mathrm{~mm}$ & $168 \mathrm{~mm}$ & $169.7 \mathrm{~mm}$ \\
\hline Ancho Máx. del cráneo (eu-eu) & $135.6 \mathrm{~mm}$ & $135.0 \mathrm{~mm}$ & $126.7 \mathrm{~mm}$ & $122.8 \mathrm{~mm}$ \\
\hline Índice cefálico & 79.11 & 84.85 & 75.41 & 72.36 \\
\hline
\end{tabular}

Tabla $N^{\circ}$ 2.- Medidas craneométricas de los 4 cráneos analizados de Purunmarca, Vichaycocha, alto Chancay. 


\section{5.- UNIDAD 11}

Contexto funerario en cista: Se recuperaron abundantes restos óseos de animales al interior de la cista. En la parte superior se halló las siguientes partes de una alpaca:

- Cabeza: 2 fragmentos de cráneos, 1 bulla timpánica y 1 arco cigomático,

- 2 vértebras cervicales joven, 1 torácica joven (disco vertebral) y 9 costillas de alpaca joven de 1.5 años de edad, al parecer resto de dieta funeraria.

- 4 fragmentos de húmeros (2 diáfisis, 1 proximal y 1 distal) de adulto- joven, 1 pelvis (porción del acetábulo), 2 rótulas completas de alpaca de 1-1.5 años de edad, 1 metapodio distal y 1 astrágalo derecho joven completo.

Por debajo y en otro nivel se halló los restos mezclados de una llama y una alpaca quemados, asados y mordidos, al parecer luego de haber sido preparados asados como "pachamanca", fueron ofrendados:

- 1 incisivo central del tipo llama (Lama glama) muy desgastado y fracturado de la cara oclusal por golpe violento. 1 segundo molar de llama joven de 1-1.5 años de edad. Además, hay 10 fragmentos de cráneo de alpaca joven de 1.5-2 años de edad.

- 6 costillas chancadas y mordidas, 8 vértebras (6 torácicas y 2 cervicales), quemadas y asadas, 2 pelvis.

- 4 fragmentos de epífisis distal de húmero: asado, chancado y cortado; 4 radio-cúbitos de individuos jóvenes, 7 tibias, 4 diáfisis y distal (3), 4 metapodios; 2 diáfisis y 2 epífisis distal, 1 calcáneo derecho de alpaca, astrágalo derecho con marcas de corte (ver figura), 4 falanges y 2 tarsianos.

Además, se halló en otro lado de la cista (casi al fondo) los siguientes restos óseos de camélidos: Una vértebra torácica; 1 costilla derecha chancada; 1 escápula derecha fragmentada; 2 fémures jóvenes distal, 1 distal de tibia fragmentado de individuo adulto. 1 diáfisis de fémur; 1 tibia fragmentada y 1 diáfisis de metapodio; 1 metatarsiano izquierdo completo joven de alpaca; 5 tarsianos completos de alpaca joven.

Se halló también los restos de por lo menos dos guanacos (adulto y joven): tres fragmentos de cráneo; 1 mandíbula derecha de guanaco adulto; 2 pelvis fragmentadas chancadas; 8 vértebras adultas; 1 rótula completa; 1 escápula derecha de guanaco; 5 epífisis proximal y distal de húmero, 3 diáfisis de húmeros jóvenes; 4 diáfisis de radio-cúbito; 3 proximal de fémures; 1 primera falange distal de guanaco y 3 tarsianos.

También hay restos de taruca (Hippocamelus antisensis): vértebra lumbar adulto, chancado, fragmentado y asado; cuatro costillas fragmentadas joven: un cráneo fragmentado en la base del occipital, adulto; un esternón chancado, 2 pelvis chancadas, una diáfisis de fémur chancado, una esquirla de tibia y una segunda falange joven.

En asociación se recuperó al interior de la cista restos de un cernícalo o killinchu (Falco sparverius): 1 metacarpo derecho completo de ave rapaz robusto. Se recuperaron solo seis huesos humanos y un diente, pertenecientes a un individuo de sexo femenino adolescente-adulto (16-18 años de edad): una vértebra lumbar (L5), un primer metacarpo del dedo gordo de mano izquierda, un diente premolar inferior completo joven con desgaste oclusal por consumo de hoja de coca, una vértebra torácica de que ha ejercido mucha fuerza con entesopatía en cuerpo vertebral, una costilla izquierda, una falange de mano ( $2^{\circ}$ falange completa) y una primera falange del dedo gordo del pie derecho con entesopatía.

Entre los restos se halló también una pelvis de camélido, trabajada y utilizada como una herramienta textil tipo cardador o alisador de cuero de alpaca (ver figura). 


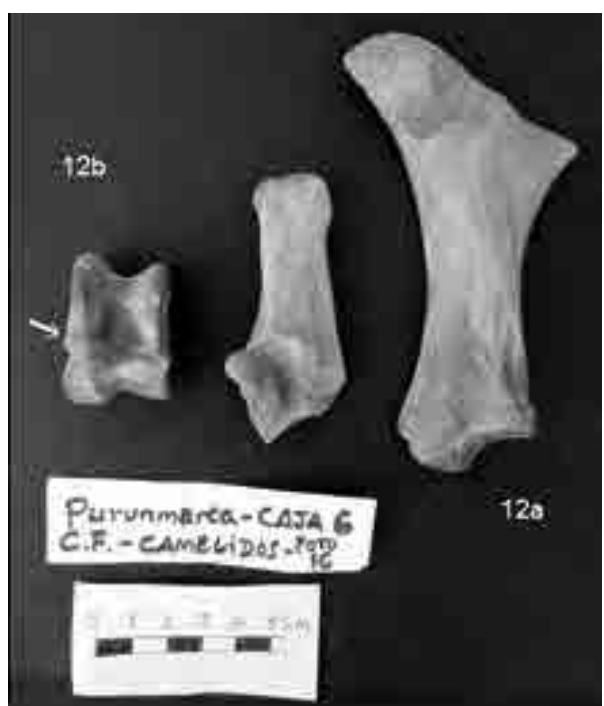

Figura 101: 12a y 12b.- Instrumento textil de los pastores Atavillos, hallado en contexto funerario y huesos de astrágalo y calcáneo con marcas de corte.

\section{6.- UNIDAD 14}

Contexto funerario 1: se recuperó los restos óseos correspondientes a por lo menos 15 individuos (8 niños bebes $\mathrm{y} 7$ adultos) de diferente sexo:

- 75 fragmentos de cráneo, 15 mandíbulas, 8 niños y bebés, 7 adultos (2 edentados); 9 dientes sueltos, de los cuales 2 tienen severo estrés producto de la hipoplasia (ver figura).

- 16 fragmentos de vértebras cervicales, 53 vértebras torácicas y 43 vértebras lumbares, hay 3 con espondilólisis, con criba orbitalia y modelación cefálica de masculino; 205 costillas entre adulto, jóvenes y niños

- Dedos falanges fusionados de mano derecha con artritis (ver figura).

- 16 fragmentos de pelvis, 13 clavículas (5 bebés y 7 adultos), 6 esternón e incluye uno con fosa esternal pequeña de un masculino adulto (ver figura).

- Extremidades superiores: 10 carpianos de adultos - jóvenes, 5 sacro adulto, 32 metacarpos, 32 falanges de mano

- Extremidades inferiores: 15 escápulas (10 adultos y 5 neonato). 6 rótulas adultos completas, 5 calcáneos ( 3 adultos y jóvenes), 7 astrágalos ( 5 adultos y 2 jóvenes), 7 cuneiformes de adultos, 13 húmeros ( 6 adultos y 7 bebés), 11 radios ( 3 adultos y 8 bebés), 8 cúbitos ( 2 adultos y 6 bebés), 12 fémures ( 3 adultos y 9 bebés), 12 tibias ( 2 adultos y 10 bebés), 20 peronés (13 adultos y 7 bebés), 36 metatarso y 10 falanges del pie.
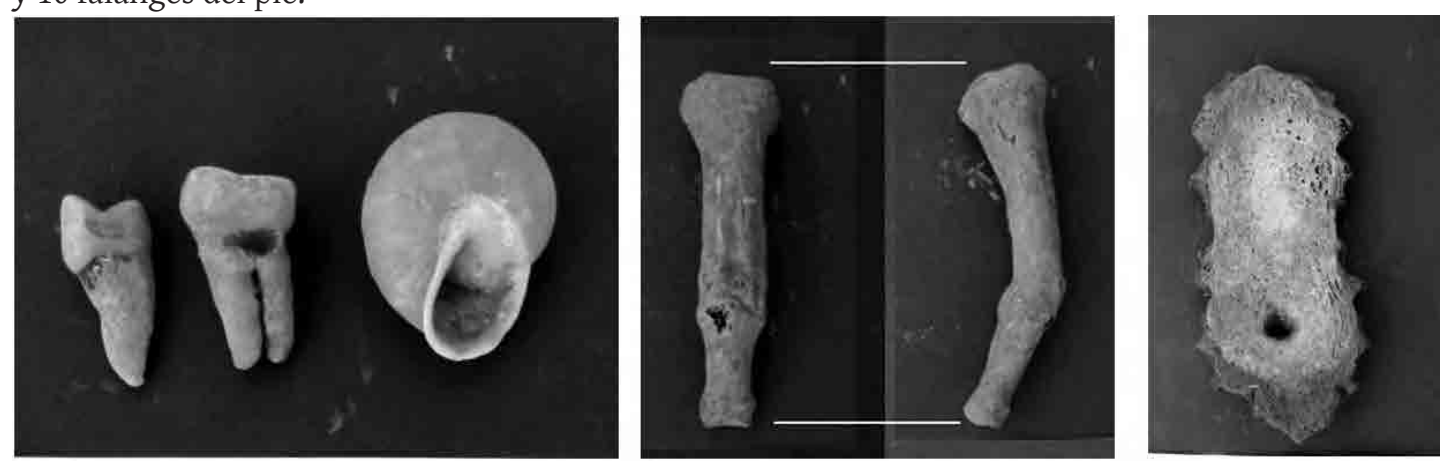

Figura 102 (izquierda): Dientes premolares con severo estrés por hipoplasia humanos adultos. Figura 103 (centro): Falanges fusionadas de la mano derecha de hombre adulto con artrosis. Figura 104 (derecha): Fosas esternal de masculino adulto de Purunmarca, Vichaycocha.

Además, se halló restos óseos de animales que formaban parte de las ofrendas o asociaciones:

- Camélido (NMI: 2): 9 fragmentos de cráneo, 1 mandibula adulta, 20 vértebras de joven entre cervicales y torácicas, 1 sacro, 2 pelvis, 7 costillas, 1 esternón, 1 escápula joven derecho, 2 rótulas de 1.5 años de edad completas, 2 húmeros con diáfisis, 1 radio-cúbito adulto-joven, 3 fémures jóvenes, 1 tibia distal adulto-joven, 4 metatarsiano ( 2 derechos y 2 izquierdos), 4 carpianos y 3 tarsianos adulto-joven, 1 astrágalo derecho completo tierno, 3 primeras falanges y 3 segundas falanges. 
- Cérvido: taruca (Hippocamelus antisensis): 1 diáfisis de húmero adulto, 1 metatarsiano adulto proximal, 1 cuarto tarsiano y 1 primera falange completa.

Contexto funerario 3: Como parte de este contexto se recuperó abundantes restos óseos humanos correspondientes a varios individuos, entre adultos y niños, como mínimo 3 adultos, 3 jóvenes, 4 niños y 3 neonatos (13 individuos):

- 11 fragmentos de cráneo, 7 mandíbulas (3 adultos y 4 niños).

- 73 fragmentos de costillas, 21 vértebras cervicales y torácicas, 25 vértebras lumbares.

- 9 clavículas completas (3 adultos, 3 jóvenes y 3 neonatos).

- 1 sacro adulto masculino con crecimiento anormal de la cresta sacral posterior por golpes o anomalía congénita (ver figura), 3 esternones y uno posee fosa esternal (Fig. 17), 10 escápulas (4 adulto y 6 joven).

- Extremidades superiores: 6 húmeros (1 adulto, 1 niño y 4 bebés); 8 cúbitos (3 adultos y 5 neonatos), metacarpos (19 jóvenes), 14 falanges de la mano completos.

- Extremidades inferiores: 11 fragmentos de pies, 6 fémures (2 niños y 4 neonatos), 4 tibias (1 derecha tiene osteomielitis: con cloaca o secuestro por infección por Estafilococus aureus de individuo masculino adulto que sufrió severo trauma en la rodilla, ver figura), 2 peronés ( 1 adulto y 1 joven), 1 carpo femenino adulto completo, 4 calcáneos adultos, 4 astrágalos adulto y 4 cuneiformes, 17 metatarsos casi todos completos y 3 falanges completas del pie.
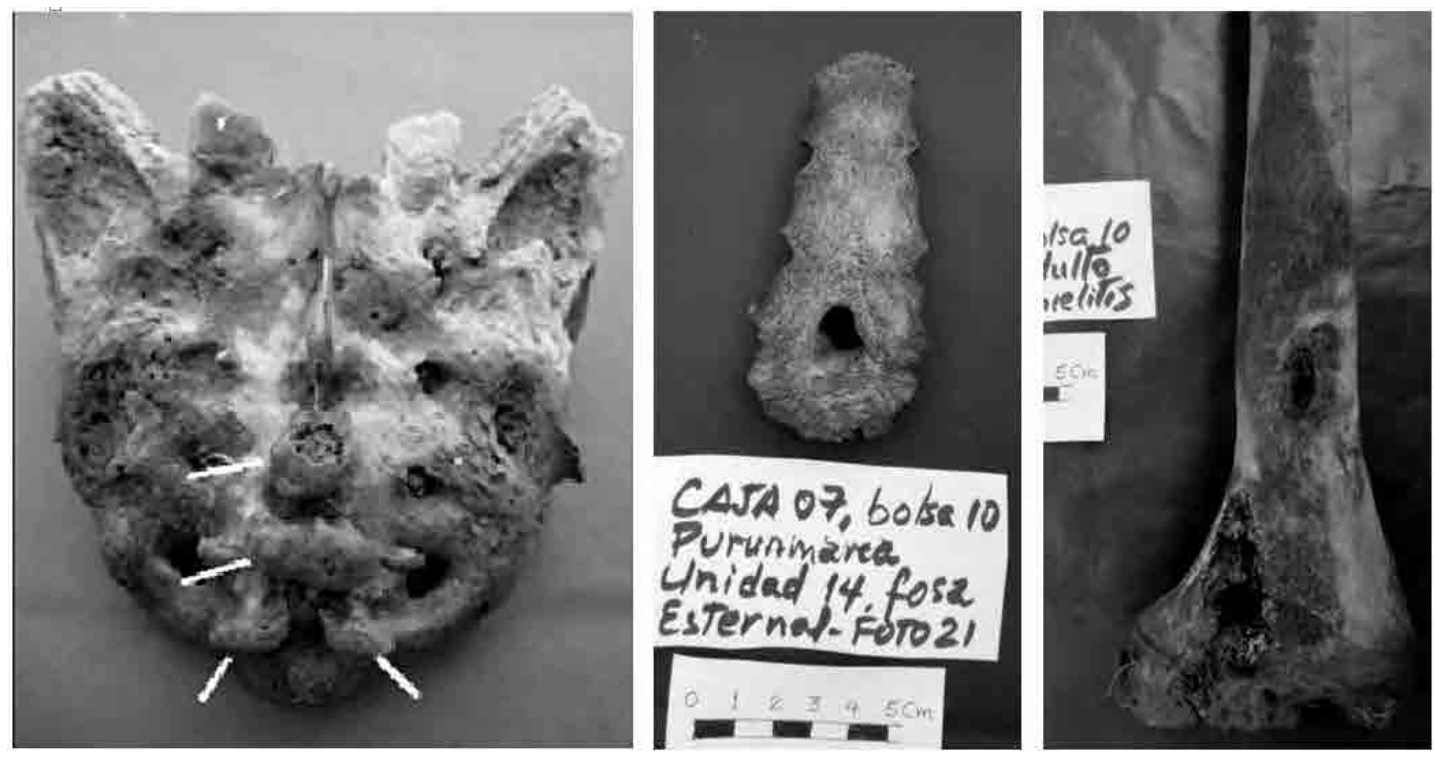

Figura 105 (izquierda): Sacro adulto masculino con crecimiento anormal en la cresta sacral inferior por golpes o lesiones congénitas. Figura 106 (centro): Fosa esternal de adulto masculino por anomalía congénita. Figura 107 (derecha): Osteomielitis de tibia derecha de masculino adulto por severo trauma en la rodilla.

Además, se encontró restos óseos de animales que se encontraban asociados a los individuos a modo de ofrendas:

- Camélidos (NMI:3): 1 cráneo fragmentado, 2 mandíbulas y 1 diente incisivo de llama, 1 esternón, 2 pelvis, 1 costilla joven, 2 escápulas jóvenes, 5 húmero de animales joven, 4 radio-cúbitos jóvenes, 
diáfisis, 6 vértebras ( 3 cervicales y 3 dorsales), 5 metapodios (proximal y distal), 5 primeras falanges y 1 segunda falange completa, 1 rótula y 1 maleolo lateral.

- Cérvido (NMI: 2): taruca (Hippocamelus antisensis): 1 mandíbula derecha joven, 2 frontales y bases de astas, masculinos joven, 1 escápula quemada completa y 2 primeras falanges y 1 segunda falange completa de adulto.

- Vizcacha (Lagidium peruanum): 1 tibia completa derecha.

- Cuy: (Cavia porcellus): 1 cráneo y 1 mandíbula izquierda chancada y asociado a los entierros.

\section{7.- Unidad 15}

Contexto funerario 1: Entre los restos óseos humanos (por lo menos 2 bebes femeninos, un niño y 2 individuos adultos entre los cuales hay una mujer de 18-24 años y un joven de sexo masculino) recuperados de este contexto figuran:

- Bebés: 3 cráneos fragmentados (2 femeninos), menores de 1.5 años de edad con modelación cefálica semi-alargado horizontal; 1 escápula izquierda fragmentada, 1 íleon de pelvis, 1 clavícula izquierda completa de bebé, 6 falanges mano, 12 costillas de bebés, 4 vértebras no soldadas, de bebé, 2 húmeros izquierdo y derecho, 1 radio y 1 cúbito izquierdo de bebé, 1 fémur izquierdo y 2 tibias izquierdo y derecho de 1 bebé.

- Individuos adultos: Un individuo femenino robusto, adulto-joven (18-24 años) con 34 fragmentos de cráneo, por el fuerte desgaste dentario se infiere que el individuo chacchaba coca, tiene modelación cefálica del tipo semi-alargado en el eje sagital. 18 costillas de mujer adulto-joven, 3 fragmentos de pelvis todo con cal erosionado de mujer. 17 fragmentos de vértebras: 3 cervicales, 10 torácicas y 4 lumbares, una con espondilólisis (callo óseo en el cuerpo vertebral de lumbar); 4 clavículas: 1 masculino adulto, 1 femenino joven y 2 niños; 4 cúbitos adultos y 1 de ellos presenta la fractura de Parry (callo óseo formado a la altura de la diáfisis y osificado en la metáfisis distal oblicua del cúbito); 4 radios: 3 adultos y 1 joven de 5-7 años, todos fragmentados; 1 tibia derecha femenino adulto-joven con gran callo óseo en la parte baja de la diáfisis por impacto de roca que levantó esa parte ósea, todo cubierto de cal; 6 peronés de adulto-joven, sólo uno de ellos está completo; 3 calcáneos, 1 cuneiforme y 4 carpos completos de 3 individuos diferentes; 18 falanges de la mano y pie (4 del pie y 14 de la mano), completos de adulto-joven. Todos los restos óseos están chancados y cubiertos de cal, fracturados intencionalmente post mortem (ritual de quema).

Además, se ha encontrado restos óseos de animales que formaban parte de las ofrendas:

- Camélidos: Se identificó una llama tierna (menor de 2 meses): 3 fragmentos de cráneo, 2 húmeros con diáfisis (izquierdo y derecho), 2 fémures (izquierdo y derecho), 2 radio-cúbito no fusionados y 3 metapodios no fusionados. Además, se identificó los restos de una llama adulta: fragmento de cráneo, 3 costillas quemadas (tipo holocausto), 4 vértebras cubiertas de cal, 2 húmeros diáfisis y 2 radio-cúbitos, 2 fémures, 2 tibia chancadas, 7 metapodios (4 quemados, en ritual de holocausto), 3 carpianos, 1 falange quemada. Además se identificó los restos de una alpaca joven: 1 mandíbula y una vértebra rajada. Se identificó también 7 radio-cúbitos de llama.

- Roedor: pequeño o ukush (Phyllotis pictus): 1 escápula derecho joven, 1 sacro joven y 1 húmero izquierdo joven.

- Cérvido: taruca (Hippocamelus antisensis): 1 molar desgastado superior, 1 astrágalo derecho completo y un cuarto tarsiano completo. 
También se identificó entre los restos óseos recuperados del contexto, algunos objetos que formaban parte de los materiales asociados: Un tupu pulido de tibia de camélido; una asta de taruca macho desgastado en la base y ápice; un alisador o espátula de pelvis de guanaco adulto con fractura post-mortem ( "illa"), 2 placas ovales de escápula de camélido con perforación en el centro y un tupu de hueso de camélido (ver figura).

\section{Caracterización de los ConteXtos funerarios Atavillos en Purunmarca}

\section{1.- Las estructuras funerarias}

La mayoría de los casos de estructuras funerarias identificadas en las excavaciones del sitio de Purunmarca corresponden a cámaras funerarias dispuestas al interior de los kullpis. Estas cámaras son en su mayoría de forma y planta irregular, conformando las áreas dispuestas alrededor de las cámaras principales o recintos, hallándose a diferentes niveles con respecto a la superfi-

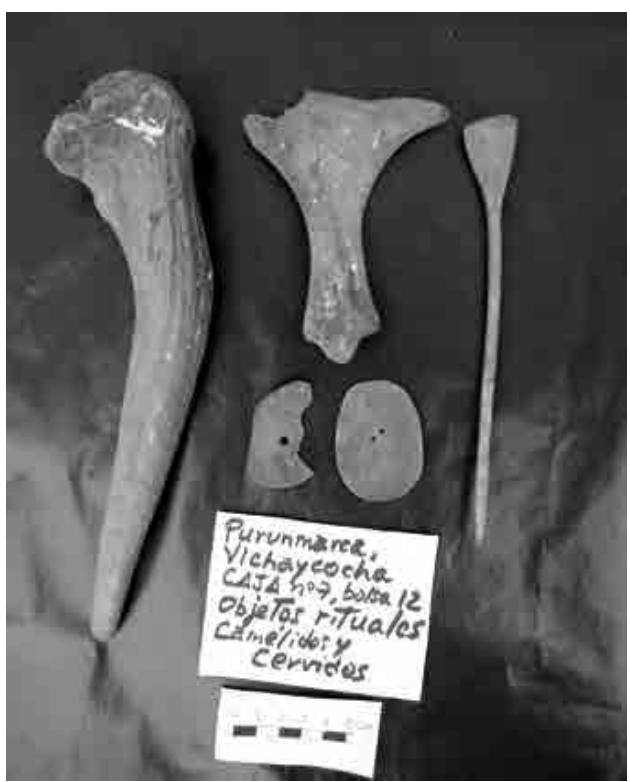

Figura 108: Objetos rituales de camélidos y cérvidos: alisador illa, una asta martillo, discos y un tupu. cie de actividad interna de los kullpis o recintos.

\begin{tabular}{|c|c|c|c|c|c|c|}
\hline \multirow{2}{*}{ Unidad } & \multirow{2}{*}{ Contexto } & \multirow{2}{*}{ Forma } & \multicolumn{3}{|c|}{ Dimensianes de la estructura $(\mathrm{m})$} & Tipo de \\
\cline { 4 - 6 } & & Largo & Ancho & Altura & estructura \\
\hline 2 & 02-CF1 & Irregular & 0.54 & 0.44 & 0.55 & Cámara \\
\hline 2 & 02-CF1 & Rectangular & 0.60 & 0.50 & 0.12 & Cista \\
\hline 3 & $03-$ CF1 & Ovalado & 0.65 de diámetro & 0.40 & Cámara \\
\hline 7 & $07-$ CF1 & Irregular & 0.50 & 0.38 & 0.25 & Cámara \\
\hline 9 & $09-$ CF1 & Irregular & 1.50 & 0.80 & 0.80 & Cista \\
\hline 11 & $11-$ CF1 & Irregular & 1.35 & 0.85 & 0.60 & Cista \\
\hline 14 & $14-$ CF1 & Irregular & 0.60 & 0.50 & 0.70 & Cámara \\
\hline 14 & $14-$ CF2 & Rectangular & 0.60 & 0.50 & 0.70 & Cámara \\
\hline 14 & $14-$ CF3 & Irregular & 1.20 & 0.70 & 0.45 & Cámara \\
\hline 15 & $15-$ CF1 & Irregular & 0.80 & 0.50 & 0.45 & Cámara \\
\hline
\end{tabular}

Tabla $N^{\circ}$ 3: Características de las estructuras funerarias excavadas en Purunmarca.

\section{2.- Características de los individuos}

Existen dos estructuras funerarias que presentan en el interior ofrendas de animales (camélidos y cánidos), relacionados con las ceremonias constructivas de los edificios Kullpi. El resto de estructuras funerarias presentan individuos humanos, presentándose un mayor porcentaje de individuos adultos (44\%), seguido por los niños (26.3\%). Los neonatos se presentan en un $22 \%$, mientras que los individuos jóvenes en un 7.7\% de frecuencia del total de individuos identificados. Existen estructuras funerarias que presentan solo niños del mismo sexo, mientras que los neonatos se presentan indistintamente y estarían relacionados a ofrendas o sacrificios para acompañar a sus padres.

\section{3.- Asociaciones y ofrendas}

Entre los materiales asociados en los contextos funerarios figuran: fragmentos cerámicos, óseos animales y artefactos elaborados de huesos o de metal. Se han encontrado escazas vasijas completas en el interior de las estructuras funerarias. 


\begin{tabular}{|c|c|c|c|c|c|c|}
\hline \multirow[t]{2}{*}{ Unidad } & \multirow[t]{2}{*}{ Contexto } & \multicolumn{5}{|c|}{$\begin{array}{l}\text { Nùmero minimo de individuos humanos } \\
\text { (completos o parciales) }\end{array}$} \\
\hline & & Neonatos & Niños & Jóvenes & Adultos & Total \\
\hline 2 & $02-\mathrm{CF} 1$ & 2 & - & 3 & - & 5 \\
\hline 2 & $02-\mathrm{CF} 1$ & - & - & - & - & - \\
\hline 3 & 03-CF1 & 5 & 4 & - & - & 9 \\
\hline 7 & 07-CF1 & - & 5 & - & - & 5 \\
\hline 9 & 09-CF1 & 5 & 5 & & 29 & 39 \\
\hline 11 & 11-CF1 & - & - & - & - & - \\
\hline 14 & 14-CF1 & 3 & 5 & & 7 & 15 \\
\hline 14 & 14-CF2 & & & & 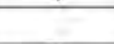 & \\
\hline 14 & 14-CF3 & 3 & 4 & 3 & 3 & 13 \\
\hline 15 & 15-CF1 & 2 & 1 & 1 & 1 & 5 \\
\hline \multicolumn{2}{|c|}{ TOTAL } & 20 & 24 & 7 & 40 & 91 \\
\hline
\end{tabular}

Tabla $N^{\circ}$ 4: Densidad de individuos humanos recuperados de los contextos funerarios excavados en Purunmarca.

La presencia de restos óseos de tarucas, luychus, guanacos y vicuñas en los contextos funerarios de Purunmarca nos permiten inferir que la caza de estos animales de puna y sierra interandina era intensa, jugando un papel importante en la economía de los Atavillos. Además, se infiere que la población de estos animales era copiosa. Los pastores de camélidos complementaban sus dietas con la caza de estos animales silvestres, principalmente en determinadas fiestas cíclicas donde ocurrían las muertes de los héroes, personajes destacables de la sociedad local o posiblemente en ofrendas de los primeros meses de cada año, marcados por los solsticios. Es decir, la caza de venados, guanacos y vicuñas a modo de chaco para el banquete ritual sería muy común en esta sociedad Atavillana y sus restos fueron posteriormente depositados en ajuares funerarios a modo de ofrendas.

Concernientes a las illas de los camélidos se puede entender que su presencia en la zona indica la elevada sacralidad de esta simbología en relación a la fertilidad y el culto al agua. Estos huesos de pelvis tallados, en un principio servían para alisar cueros de los camélidos (función económica) y luego, cuando se deposita en el contexto funerario adquiere la connotación de illa (función ritual). Asimismo, consideramos que las relaciones socioculturales entre los Atavillos eran intensas reflejadas en la cosmovisión de las illas. La Illa tiene la simbología del relámpago y del rayo; su padre es el rayo Illapa y su madre el puquio. También es la roca, árbol u otro objeto herido por el rayo y, por tanto, considerado sagrado o huaca; representa la alpaca sagrada y fuertemente venerada por poblaciones altoandinas relacionadas a la crianza de camélidos (Altamirano; 2015:Ms).

Entre los objetos suntuosos asociados en las estructuras funerarias figuran: instrumentos musicales como flautas, conopas líticas (una de ellas con la representación de una mazorca de maíz), tupus de hueso y de metal, prendedores de metal, piruros de cerámica y artefactos líticos.

\section{Caracterización de los individuos Que Vivieron en Purunmarca a PartiR DEL ANÁLISIS DE SUS RESTOS ÓSEOS}

\section{1.- Deformación craneana o modelación cefálica}

Se han detectado dos tipos de modelaciones cefálicas del tipo Atavillos: uno de forma vértico-bregmático y otro semi-alargado horizontal, ambos son de origen serrano propios de la zona. El tipo semi-alargado horizontal es más común en los asentamientos de la cuenca alta del río Chancay como en Purunmarca (Hanan Atavillos), en cambio, el tipo Vértico-bregmático es más común en los asentamientos de menor altitud como Rupac (Hurin Atavillos). Los intensos enfrentamientos rituales 
entre hombres y mujeres con estas modelaciones cefálicas producían muertes de los combatientes, los cuales eran héroes de guerra y depositados solemnemente en Purunmarca, como un gran santuario de los "abuelos" que sacrificaron sus vidas para los dioses andinos de los apus, la perpetuidad del agua y la pachamama.

A través de las asociaciones estratigráficas y los cráneos modelados podemos plantear hipotéticamente tres fases culturales de los Atavillos: temprano, medio y tardío. En la fase Temprana que corresponde a fines del Horizonte Medio, cuando se inician la llegada de poblaciones con el tipo vértico-bregmático, tal vez procedente de Pasco y la sierra central, que se caracterizan por una pronunciada y elevada área bregmática, tratando de causar temor a sus adversarios en las batallas, esto probablemente estaría ocurriendo entre 700-1100 d.C.

Durante la fase Media que corresponde al período Intermedio Tardío (1100-1460 d.c.) surge el tipo semi-horizontal asociado con la tradicional vértico-bregmático, ambas formas conviven en forma de guerras o batallas interpersonales a fin de controlar y dominar las tierras de pastoreo y caza. Este tipo caracterizaría a los Atavillos y se difunde en las zonas durante este período, teniendo fuerte interrelación socioeconómica con los Chancay.

Durante la fase Tardía u Horizonte Tardío (1460-1535 d.c.), que corresponde a la ocupación Tawantinsuyu en la zona, se interrelacionó con el resto del imperio mediante el Qhapaq ñan, los Atavillos pasan a ser dominado por los cusqueños, los cuales respetaron la vieja ideología de las modelaciones cefálicas, a los apus locales y el culto a la illa. Esperamos contrastar este modelo con futuras investigaciones bioculturales en la cuenca alta del río Chancay (Tabla $\mathrm{N}^{\circ}$ 5).

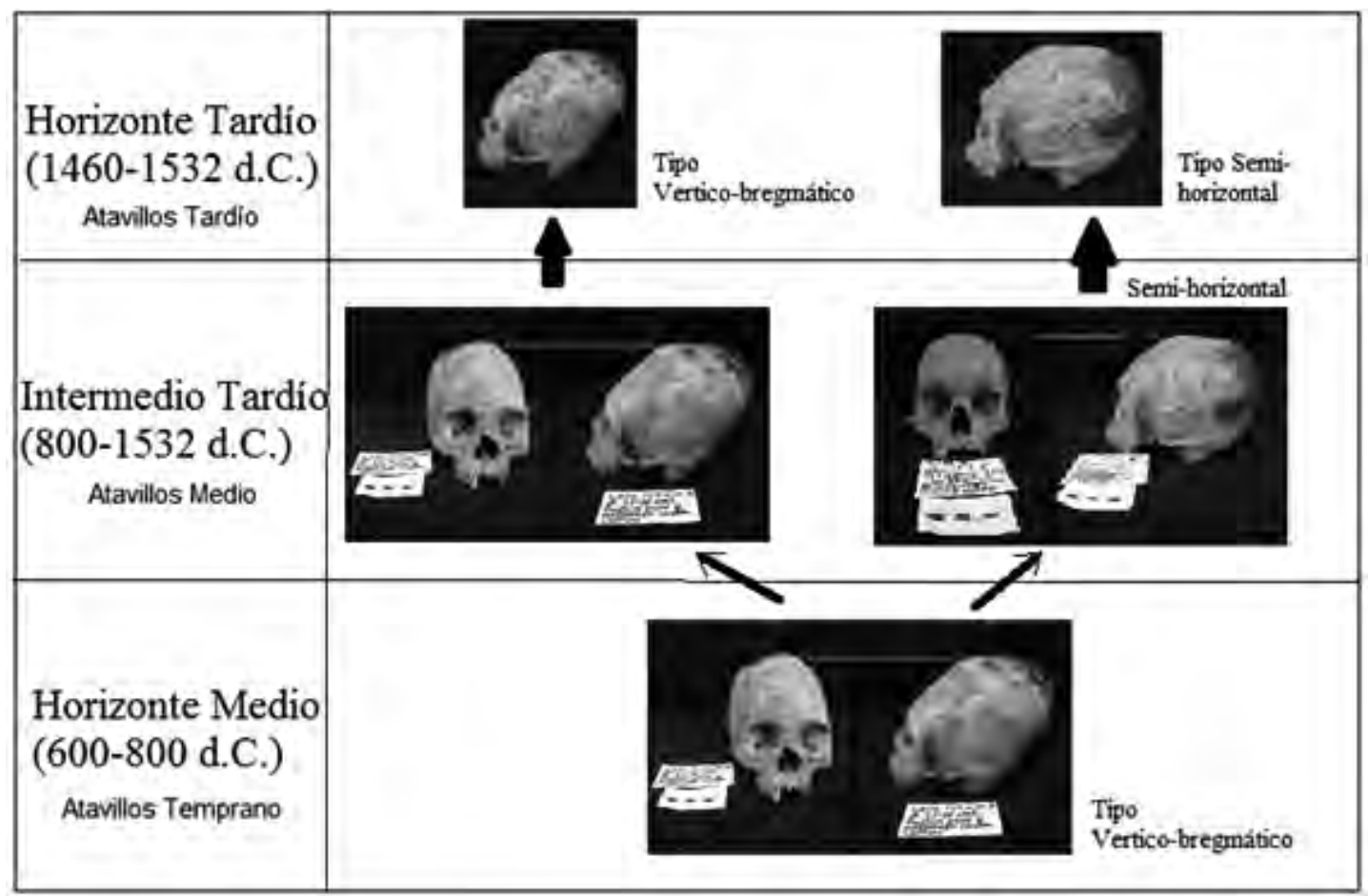




\section{2.- Paleopatologías de la población de Purunmarca}

El caso de leishmaniasis (unidad 9) se trata del cráneo, denominado $\mathrm{N}^{\circ} 10$, pertenecía a un individuo femenino adulto de 16-18 años de edad con severa infección ocular y criba orbitalia con modelación cefálica vértico-bregmático. Al respecto podemos inferir que esta patología infecciosa o uta solamente se adquiere en tierras cálidas de la chaupiyunga, tanto de las vertientes orientales cuanto occidentales. Es posible mencionar que la mujer pastora joven de camélidos habría bajado a las tierras cálidas de los valles interandinos o chaupiyunga donde, siendo allí picada por la Lutzomyiay, produciendo que la enfermedad se desenvuelva en el globo ocular izquierdo infectándolo intensamente y perdiendo este ojo. Se viajaba intensamente en busca de las hojas de la coca para los sacrificios a las montañas calmar los intensos dolores de dientes que sufrían los hombres de la región de los Atavillos y el desarrollo de actividades religiosas (Van Dalen 2012a).

Los fuertes desgastes dentarios, perdidas de premolares y primeros molares, y la presencia de raigones expuestos y caries dentarias indican que estos grupos humanos sufrían problemas odontológicos y para calmar los dolores intensos se consumía la hoja sagrada de la coca (Indriati; 1998), la cual llegaba del valle medio del río Chancay. La lesión de osteomielitis de un individuo adulto masculino que afectó fuertemente a la tibia derecha con cloaca o secuestro confirma las luchas interpersonales produciéndose traumatismos.

Las entesopatias de brazos y antebrazos indican la robustez de los individuos, cargando peso o luchando contra otras poblaciones vecinas usando hondas o huaracas. Asimismo, la hipervascularización de las tibias, rodillas, fémures y pelvis apuntan que estos hombres de Purunmarca realizaban intensas caminatas por las quebradas y valles interandinos. La alta incidencia de osteofitosis y espondilólisis de las vértebras lumbares señalan que estos hombres cargaban pesos mayores de 40-50 kilos cuando se desplazaban a gran distancia con sus recuas de camélidos o durante la actividad cinegética de cérvidos, guanacos y vicuñas. Las constantes luchas por el control del agua y tierras entre los Atavillos, divididos en altos y bajos, en el Tawantinsuyo eran protegidos por sus apus tutelares como el de Antajirca (Villar; 1935) y el Cerro Chuquimango (Cáceda; 2014), la cual era la divinidad tutelar de los Atavillos en las subcuencas del Chacur y Añasmayo donde se encuentran los asentamientos de Rupac, Añay y Chiprac. Las luchas o "deportes andinos" ya eran intensas desde tiempos prehispánicos tardíos, donde los mallquis o ancestros jugaban un papel preponderante.

\section{3.- Evidencias de violencia social}

Las evidencias arqueológicas en general demuestran que las sociedades altoandinas del Intermedio Tardío fueron sociedades altamente violentas, tanto en cuanto al enfrentamiento con sociedades vecinas por el control de tierras, recursos y agua; como por enfrentamientos con otros miembros de su misma sociedad; situación relacionada con la ausencia de productos por los cambios climáticos radicales, la escasez de tecnología material en relación a periodos precedentes y casos de etnocidios como los identificados en la sierra centro sur (territorio Chanka), (Kurin y Gómez; 2010).

Una constante en la violencia social identificada en Purunmarca es la realizada contra niños y neonatos, en su mayoría relacionados con sacrificios a personas o divinidades. Los diversos entierros de niños y bebés asociados a los osarios y contextos funerarios indican que hubo una elevada mortalidad debido a factores sociobiológicos, relacionados a los psicopompos y a "alimentos" espiritual de 
los héroes culturales para su regeneración y volver a nacer. Estos sacrificios eran solemnes en la zona y conmemoraban a los grandes héroes regionales (culto a los ancestros).

Por su parte, entre jóvenes y adultos se ha identificado evidencias de múltiples traumatismos, algunos de ellos causaron la muerte de los individuos, al parecer durante peleas interpersonales. Existen cráneos con evidencias de fracturas perimortem. De igual manera se observan huesos de extremidades superiores e inferiores con evidencias de fracturas, en especial la de Perry, muchas con evidencia de mejora y soldadura de hueso. Se ha identificado deformaciones óseas por fractura y golpes en clavículas. Se identificó traumas en rodillas, sean por golpes y por grandes trajines físicos. Un cráneo presenta meningocele por golpe cerca de la nariz. De igual manera se observa traumas dentales.

\section{4.- Indice de mortandad y esperanza de vida}

Existía un alto índice de mortandad en niños y neonatos, en el caso de los últimos sacrificados para acompañar a sus padres (principalmente a la madre) en las estructuras funerarias o como sacrificio a las divinidades. Solo un $40 \%$ de individuos llegaba a la edad adulta (20 años de edad). Era común que las mujeres tengan muchos hijos.

\section{5.- Consumo de coca}

Según los análisis realizados, toda la población de Purunmarca habría consumido hoja de coca con fines ceremoniales. Las mandíbulas y maxilares identificados presentan alta evidencia de este consumo, con pigmentaciones en los dientes y molares, como en las áreas contiguas; hay evidencia de desgaste dentario por consumo de coca mediante chaqchado. La coca era obtenida del mismo valle medio del río Chancay, hasta donde habrían acudido pobladores de Purunmarca a sembrar esta planta o a obtenerlo mediante intercambio, pues como ya se señaló se ha identificado un cráneo afectado en casi el $60 \%$ de su cara por la uta, enfermedad que se desarrolla en los valles medio y afecta principalmente a las personas que cultivan coca o maíz en la chaupi yunga.

\section{6.- Características físicas de la población que vivió en Purunmarca}

Las estaturas medias de los hombres adultos era entre 1.62 y $1.59 \mathrm{~m}$, en cambio, las mujeres adultas tenían 1.52 a $1.56 \mathrm{~m}$. La robustez de los huesos y las entesopatias indican que ellos estaban bien adaptados a su medio ambiente, caminaban bastante cargando peso y competían fuertemente entre sí a través de luchas interpersonales. Por la robustez mencionada se puede inferir que la población local desarrolló una dieta balanceada entre carne de camélidos y animales de puna como productos agrí-

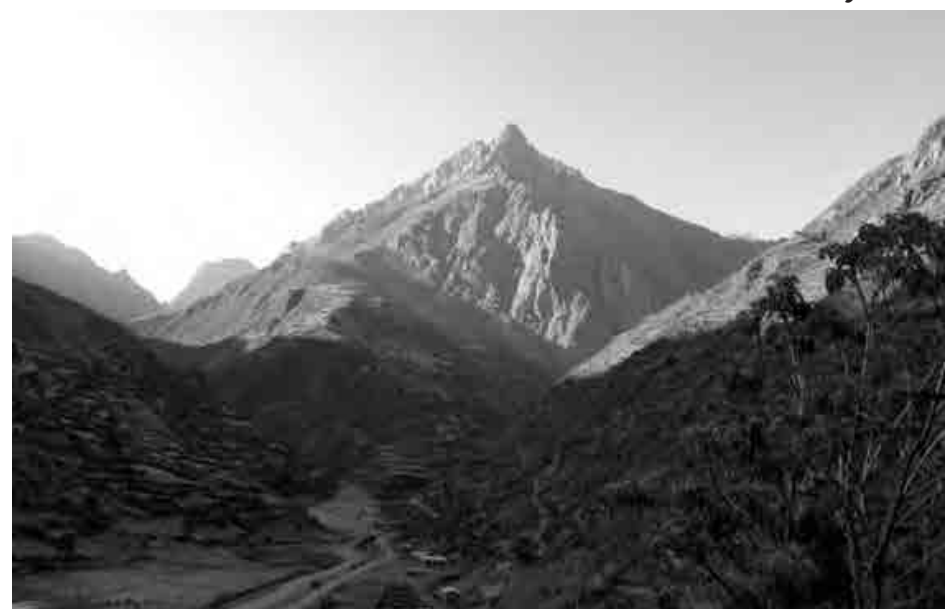
colas de la región Quechua. Sin embargo, hay evidencias de niños con parasitismo intestinal causando la criba orbitalia en el hueso frontal y estos tenían modelación cefálica del tipo Semi-alargado horizontal. Esta patología es pro-

Figura 109: Vista panorámica del apu Quirupalca ubicado frente al sitio de Purunmarca y del actual pueblo de San Miguel de Vichaycocha, antigua divinidad tutelar de la población de Purunmarca. 
ducto de infecciones gastrointestinales y anemia, causando intensas diarreas, debilitamiento, fuertes dolores y mucho llanto.

\section{CONSIDERACIONES FINALES Y CONCLUSIONES}

A través del presente artículo se ha presentado los resultados de la excavación de un conjunto de contextos funerarios (11 en total) procedentes del sitio arqueológico de Purunmarca en la localidad de San Miguel de Vichaycocha, Huaral. La mayoría de contextos funerarios fueron recuperados al interior de cámaras de kullpis o en cistas colocadas al interior de recintos o plazas. Las cámaras funerarias eran por lo general de planta irregular, de poca altitud y elaborado a base de piedras canteadas unidas con argamasa y con presencia de pachillas.

La densidad de restos óseos recuperados en las excavaciones de Purunmarca han sido considerables, pues estos materiales presentan casi igual densidad incluso que el material cerámico (cerca de 2,500 fragmentos óseos humanos y animales conteniendo huesos humanos de todas las edades y de animales de diferentes géneros como: camélidos, cérvidos, cuyes, vizcachas, fósiles de caballos americanos entre otros). Cabe señalar, que al interior de los contextos funerarios hay una alta incidencia de entierros de niños y bebés muy deteriorados y fragmentados, al parecer relacionados con sacrificios a los ancestros o a las divinidades.

Se ha podido identificar que casi el 100\% de individuos recuperados de las excavaciones presentan modelación cefálica, siendo esta de dos tipos: vértico-bregmático y otro semi-alargado horizontal, tipos de modelación característicos de la cuenca alta del río Chancay-Huaral (Atavillos). Se ha identificado casos de paleopatologías y malformaciones en los restos óseos humanos como: leishmaniasis en la cara de un cráneo, osteomielitis, traumatismos, entesopatias de brazos y antebrazos, hipervascularización osteofitosis y espondilólisis de vértebras, entre otros. Cabe señalar que existe una muestra considerable de individuos que presentan fosa esternal, característica genética propia de poblaciones de altura. Los dientes de los individuos recuperados evidencian alto consumo de hoja de coca mediante el chacchado.

Los materiales óseos humanos evidencian también altos índices de violencia social, producto de enfrentamientos con otras sociedades o con miembros de la misma sociedad. Es posible que en esta zona se hallan desarrollado enfrentamientos rituales o entre ayllus como el tipanakuy que hasta la actualidad se desarrolla en la sierra sur del Perú. Una constante en la violencia social identificada en Purunmarca es la realizada contra niños y neonatos, en su mayoría relacionados con sacrificios a personas o divinidades. Solo un $40 \%$ de individuos llegaba a la edad adulta (20 años de edad). Era común que las mujeres tengan muchos hijos. La estatura media de los hombres adultos era entre 1.62 y $1.59 \mathrm{~m}$, en cambio las mujeres adultas tenían 1.52 a $1.56 \mathrm{~m}$. Las personas eran robustas, con el aprovechamiento de una dieta balanceada entre carne de camélidos, animales de puna y productos agrícolas de la región Quechua.

Se ha encontrado al interior de los contextos funerarios numerosos restos óseos animales, los cuales fueron depositados mediante ofrendas o asociaciones. Destaca la presencia de camélidos, caballos americanos, tarucas, luychus, guanacos, cánidos, entre otros. Se ha recuperado illas elaboradas de huesos de camélidos o caballos americanos (fósiles reutilizados), utilizados en ceremonias de fertilidad y el culto al agua. De igual manera, se ha recuperado objetos suntuarios como: tupus, agujas, chocches y wichuñas, elaboradas de óseos de camélidos.

Esperamos que mayores investigaciones en otros sitios Atavillos permitan una mejor definición de esta sociedad tan poco conocida para la arqueología peruana. 


\section{RECONOCIMIENTOS}

Un reconocimiento a los arqueólogos y estudiantes que participaron en las excavaciones: A los jefes de campo: Lic. Rosa Carlos izquierdo y Lic. Alex Huamaní Cruces; a los asistentes de campo Juan Narro Alberca y Héctor Carhuas; así como a los estudiantes de la Universidad Nacional Mayor de San Marcos que participaron en las excavaciones, entre quienes mencionamos a Miller Malpartida Gamarra, Yerovi Marcelo Gonzales, Jakeline Romero Rodríguez, Lenin Fermín Flores, James Quilca Chuco, Nilver Serván Mendoza, Daivis Machaca Quispe, Flavia Malabrigo Villodas, Franco Cáceres Velásquez, Roger Allca Arone, Andrea Gutierrez Apaza, Lesly García Soto, Juan Pérez Núñez, Iván Quijano, Daniel Mansilla Banda, Benjamín Olano Zamudio, Rommel García, Víctor Rojo Cárdenas, Jesús Machado Villarreal, Carlina Garay Rebata, Natalia Cisneros, Carlos Rojas Lozano, entre muchos otros; a los profesores de la EAP de Arqueología de nuestra universidad Francisco Medina Sánchez y Rubén Wong Robles que participaron en las excavaciones. Un agradecimiento a la Comunidad Campesina de San Miguel de Vichaycocha, encabezado por su junta directiva con su presidente Sr. Arnulfo Mendoza Pastrana por el apoyo para poder realizar las excavaciones. De igual manera a José Marcelo quien nos facilitó su casa para poder alojar al equipo profesional. También nuestro reconocimiento al Dr. Alfredo Altamirano Enciso, quien realizó el análisis en gabinete de los materiales óseos recuperados de las excavaciones.

\section{BibLIOGRAFÍA}

\section{ALTAMIRANO ENCISO, Alfredo}

2014 De la huanca o lo cognitivo: el sitio arqueológico tardío de Punkayán, distrito de Huachupampa, Huarochirí, Perú. Arqueología de las cuencas alto y medio andinas del departamento de Lima. P. Van Dalen Luna, editor. Universidad Nacional Mayor de San Marcos. Lima, pp. 257276.

BUIKSTRA, Jane \& Lane BECK

2006 Bioarchaeology. Academic Press. EE.UU.

BURNS, Karen Ramey

2008 Manual de antropología forense. Ediciones Bellaterra, Barcelona.

CÁCEDA GUILLÉN, Daniel

2014 Cerro Mango Cápac: un apu atavillos en la cuenca alta del río Chancay. Arqueología de las cuencas alto y medio andinas del departamento de Lima. P. Van Dalen Luna, editor. Universidad Nacional Mayor de San Marcos. Lima, pp. 321-336.

INDRIATI, Etty

1998 A dental anthropological approach to coca-leaf chewing in the Andes. PhD Dissertation. Department of Anthropology, University of Chicago.

KURIN, Danielle y GÓMEZ CHOQUE, Enmanuel

2010 Aguerridos Chanca: una aproximación bioarqueológica desde Andahuaylas. Pacha Runa. $\mathrm{N}^{\circ} 1$. Revista del Instituto de investigaciones históricas, arqueológicas y antropológicas "Pacha Runa" - IDHAPAR. Universidad Nacional de San Cristóbal de Huamanga, Gobierno Regional de Ayacucho. Huamanga, pp. 75-98. 
UBELAKER, Douglas

2007 Análisis de los materiales óseos humanos. Traducción al castellano.

VAN DALEN LUNA, Pieter

2014a Arqueología de las cuencas alto y medio andinas del departamento de Lima, P. Van Dalen Luna, editor. UNMSM, Lima.

2014b Apuntes para el estudio de la arqueología e historia de la comunidad campesina de San José de Baños, distrito de Atavillos Alto, Provincia de Huaral. Juan Gutemberg editores, Lima.

2012a Arqueología de la chaupiyunga baja del valle Chancay-Huaral. Un análisis del territorio intermedio entre los Chancay y Atavillos. Tiempos, revista de historia y cultura. $\mathrm{N}^{\circ}$ 7. Lima, pp. 11-40.

2012b Un documento de linderos entre las comunidades deSan Pedro de Pirca y San José de Baños de 1773, Atavillos Altos, provincia de Huaral. Kullpi, investigaciones culturales de la provincia de Huaral y el Norte Chico. año 6, N 6. Lima, pp. 9-20.

2010 Investigaciones arqueológicas en Marca Piche: sitio Atavillos en Baños, cuenca alta del río Chancay-Huaral. Boletín de Lima. № 159. Lima, pp. 22-34.

2007 Reconocimiento arqueológico en la cuenca alta del río Chancay-Huaral: margen izquierda (distrito de Atavillos Alto, Santa Cruz de Andamarca y Pacaraos). Nuevos datos para comprender los procesos socio-culturales Atavillos. Revista Cultural Kullpi, Investigaciones Culturales en la provincia de Huaral y el Norte Chico. Año 3, N 3. Lima, pp. 57-148.

VILLAR CORDOBA, Pedro

1982 [1935] Arqueología del departamento de Lima. Ediciones Atusparia. 2ª Edición, Lima.

WHITE, Tim D. \& Pieter A. FOLKENS

2005 Human bone manual. Elsevier, Academic Press.

WEISS, Pedro

1960 Osteología cultural. Tomos I y II. Lima. 
